\title{
Trade and Trade Finance in the 2008-09 Financial Crisis
}

\author{
Irena Asmundson, Thomas Dorsey, \\ Armine Khachatryan, Ioana Niculcea, \\ and Mika Saito
}




\title{
IMF Working Paper
}

Strategy Policy and Review Department

Trade and Trade Finance in the 2008-09 Financial Crisis

\section{Prepared by Irena Asmundson, Thomas Dorsey, Armine Khachatryan, Ioana Niculcea, and Mika Saito}

January 2011

\begin{abstract}
This Working Paper should not be reported as representing the views of the IMF. The views expressed in this Working Paper are those of the author(s) and do not necessarily represent those of the IMF or IMF policy. Working Papers describe research in progress by the author(s) and are published to elicit comments and to further debate.
\end{abstract}

Global merchandise trade sharply declined in late 2008 and early 2009, and some press and financial market reports assigned a large role for the decline to trade finance. However, the available evidence suggests that shocks to trade finance were not the major factor in the decline in trade. Surveys of commercial banks by the IMF and others found that while bankintermediated trade finance fell in value during the crisis, it fell by less than merchandise trade. As a result, the share of world trade supported by bank-intermediated trade finance increased despite higher pricing margins. Other explanations appear to account for the bulk of the reduction in international trade.

JEL Classification Numbers:F44, G15, F32, and E44.

Keywords: Trade Finance, Crisis

Author's E-Mail Address:IAsmundson@imf.org; TDorsey@imf.org;

AKhachatryan@imf.org; iniculcea@mba2012.hbs.edu; and MSaito@imf.org. Corresponding author: Thomas Dorsey.

\footnotetext{
${ }^{1}$ This paper and especially the surveys conducted benefited from the comments and suggestions of Donna Alexander (BAFT-IFSA), Jean-Francois Lambert (HSBC), Rudolf Putz (EBRD), Thierry Senechal (ICC), and Steve Tvardek (OECD). Pille Snydstrup provided excellent editorial assistance.
} 
Contents $\quad$ Page

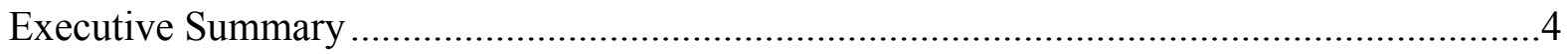

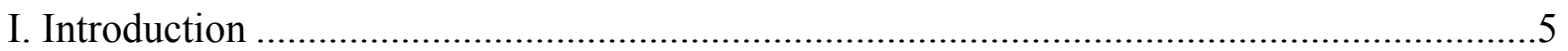

II. Trade and Financial Market Developments in 2008-09 .............................................6

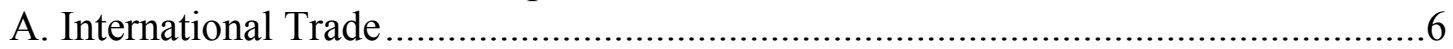

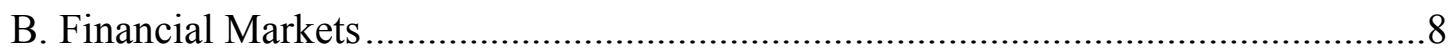

III. Evidence on Bank-Intermediated Trade Finance............................................................13

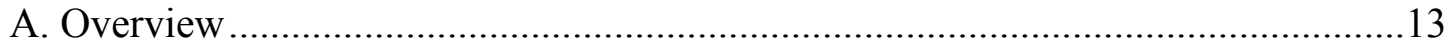

B. Value of Trade Finance .................................................................................. 15

C. Reasons for the Change in Value of Trade Finance..............................................18

D. Bank Pricing and Credit Conditions for Trade Finance.......................................22

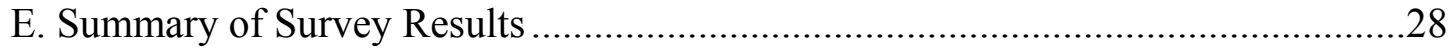

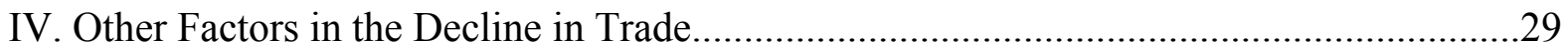

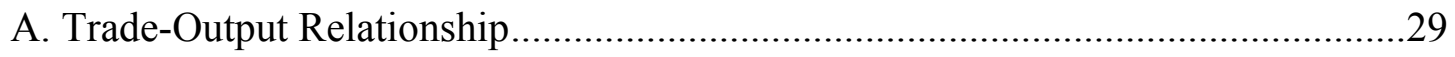

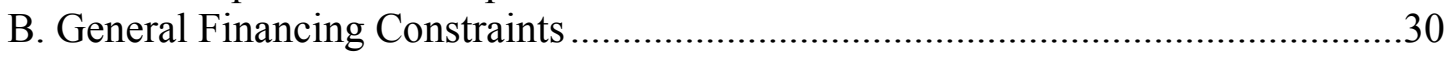

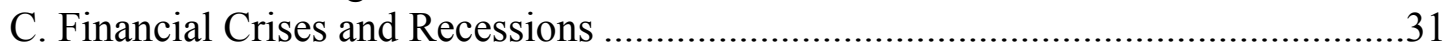

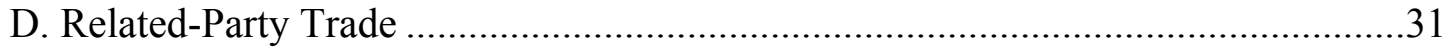

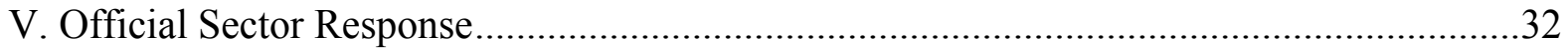

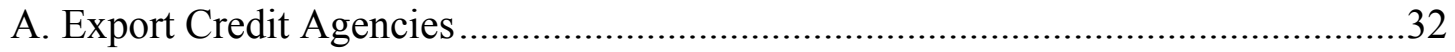

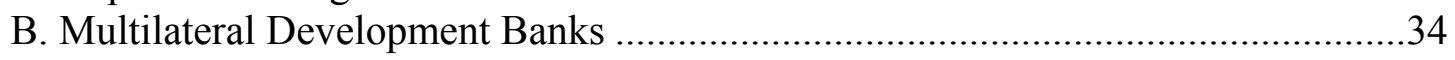

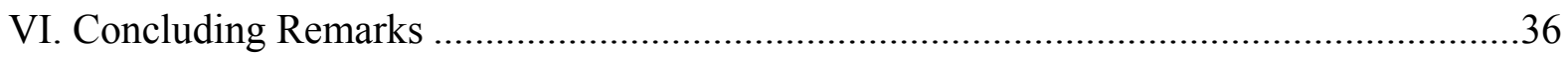

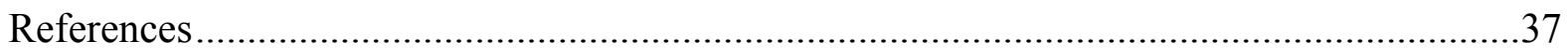

\section{TABLES}

1. Summary of Respondents ................................................................................. 14

2. Changes in Value of Merchandise Exports and Trade Finance: By Groups of Countries ..16

3. Reasons for the Decline in Value of Trade Finance .........................................................19

4. Reasons for the Increase in Value of Trade Finance .......................................................19

5. Change in Trade-Related Lending Guidelines: Tightening ..............................................20

6. Change in Trade-Related Lending Guidelines: Loosening ............................................21

7a. Pricing Changes by Size of Banks, 2008Q4 vs. 2007Q4 .............................................23

7b. Pricing Changes by Size of Banks, 2008Q4 vs. 2007Q4 ...............................................24

7c. Pricing Changes by Size of Banks, 2009Q4 vs. 2008Q4 …........................................25

8. Reasons for the Increase in Prices ............................................................................27

9. Impact of Basel II on Ability to Provide Trade Finance.................................................27

10. Related Party Shares and Trade Growth, Exports to the US .........................................32 


\section{FIGURES}

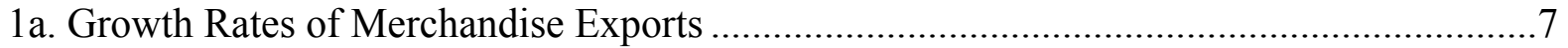

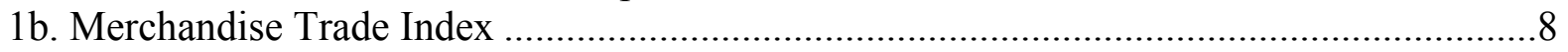

2. Global Funding Pressure..........................................................................................

3a. 3-Month LIBOR Spreads to Overnight Index Swap (OIS) ...........................................10

3b. Emerging Markets: External Debt Market Spreads ................................................ 10

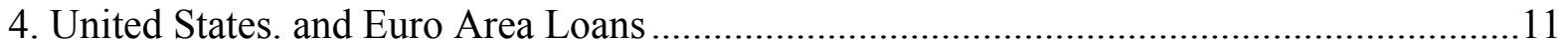

5. US Commercial Paper: Outstanding Amounts .............................................................. 11

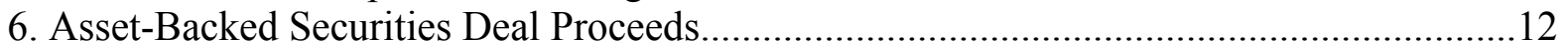

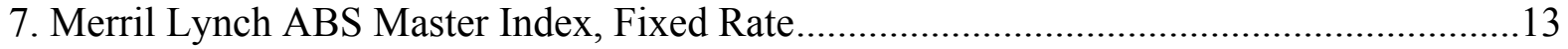

8. Overall Changes in Merchandise Exports and Trade Finance ........................................16

9. Changes in Merchandise Exports and Trade Finance: By Groups of Countries .................17

10. Best Estimate for the Composition of the Trade Finance Industry .................................18

11. Changes in Trade-related Lending Guidelines: 2009Q4 vs. 2008Q4 .............................20

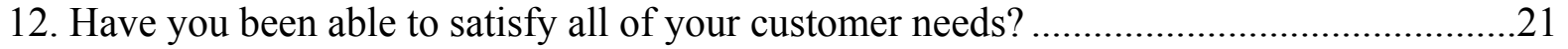

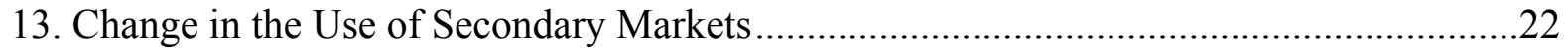

14. Recent Developments' Effect on Pricing....................................................................26

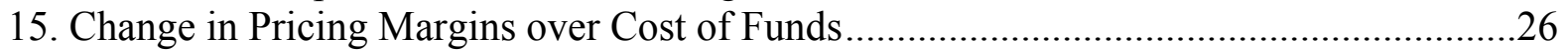

16. Change in the Probability of Default ...........................................................................28

17. Share of World Exports of Goods, Covered by Berne Union, Short-Term ......................33

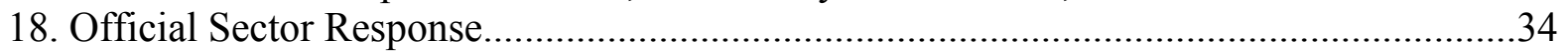

\section{BOXES}

1. Why Surveys? IMF/BAFT-IFSA and Other Survey of Banks ....................................15

2. The Response of MDBs to the Decline in Trade Finance ...............................................35

\section{APPENDIXES}

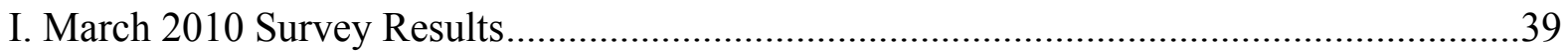

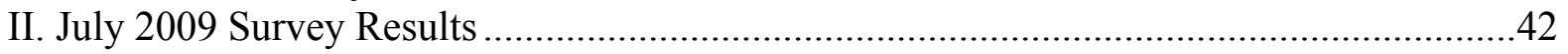

III. Trade Finance Supply and Demand Factors ...........................................................53

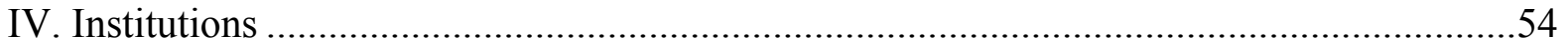

V. Measures by National Governments, ECAs, and Export-Import Banks..........................57

VI. Measures by Multilateral Development Banks.......................................................60

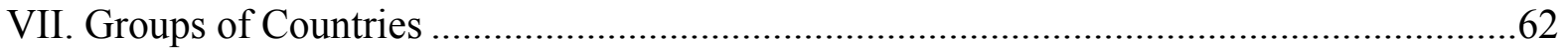

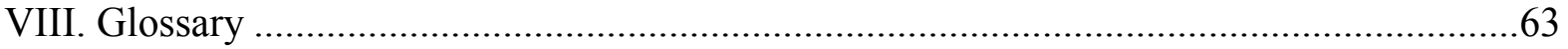




\section{Executive Summary}

1. Global merchandise trade sharply declined in late 2008 and early 2009, and some press and financial market reports assigned a large role for the decline in trade to the "collapse in trade finance." After the market disruptions from the global rise in food and fuel prices, and then the financial crisis, it was natural to think that counterparty risks were also affecting banks' willingness to provide trade finance.

2. However, the available evidence suggests that shocks to trade finance were not the major factor in the decline in trade.

- While bank-intermediated trade finance fell in value during the crisis, it fell by less that merchandise trade. As a result, the share of world trade supported by bankintermediated trade finance increased in spite of higher pricing margins.

- Pricing of trade finance products rose significantly for many banks during the crisis, although these pricing increases do not stand out from those for other commercial bank products. Moreover, there is a wide diversity in the pricing responses of individual banks and many banks did not increase trade finance pricing.

- Surveys of commercial banks by the IMF and others found an increase in the pricing and a tightening of the credit limits on trade finance during the crisis, but also a willingness of the banks to lend to support international trade for most (but not all) clients.

3. Factors other than trade finance appear to be more important in the decline in trade, although increased pricing and tightened credit conditions had undoubtedly discouraged some trade transactions that might otherwise have taken place.

- The decline in merchandise trade in the current crisis is in line with historical relationships between changes in trade and changes in output; and

- The sectoral pattern in the drop in merchandise trade does not suggest that sectors traditionally more dependent on bank-intermediated trade finance were more affected than those that make little use of bank-intermediated trade finance. 


\section{INTRODUCTION}

4. The focus of this paper is on short-term trade finance arrangements in which the banking system provides lending, insurance against nonpayment, or both in support of international trade.

5. Trade finance covers a spectrum of payments arrangements between importers and exporters. $^{2}$

- The largest share of global merchandise trade has been financed on an open account basis, in which importers repay exporters directly after receipt of goods without either insurance or lending from third parties. In this context, exporters supply both working capital to importers and take on the risk of non-payment.

- Cash-in-advance arrangements are at the opposite end of the spectrum from open account. In these, importers pay for goods before they are shipped, and this places both non-performance risk and the burden on working capital on the importer.

- Bank-intermediated trade finance allows importers or exporters to shift some of the nonpayment or non-performance risk to banks or obtain bank financing to allow the exporter to receive payment before the importer is required to make it. Insurers and other non-bank financial institutions also participate in trade finance markets in a manner similar to banks.

- There are also public sector entities such as export credit agencies (ECAs) and that have an overlapping role with commercial banks and multilateral development bank (MDB) programs that work through banks providing a secondary guarantee or liquidity to the banks.

6. Assessment of trade finance conditions is complicated by the absence of organized markets for bank-intermediated trade finance and the proprietary nature of bank information about customer relationships. To fill this gap during the current crisis, the IMF staff and the Bankers' Association for Finance and Trade (BAFT), now merged with International Financial Services Association (BAFT-IFSA) have conducted four surveys of banks on trade finance between December 2008 and March 2010 and covering developments from the fourth quarter of 2007 through the fourth quarter of 2009. ${ }^{3}$ In addition, the authors have had the opportunity to discuss trade finance with many representatives of commercial banks, ECAs, and other market participants in the context of outreach, conferences, and bilateral discussions.

\footnotetext{
${ }^{2}$ Appendices III and IV have background information on trade finance markets and institutions.

${ }^{3}$ A fifth survey was conducted in late 2010 that is not reflected here and other surveys are planned.
} 
7. This paper assesses recent developments in trade and trade finance and evidence for causes and effects to arrive at some conclusions on the role of trade finance on merchandise trade patterns during the 2008-09 crisis. Section II provides background on developments in international trade and financial markets during the crisis as context for assessing developments in trade finance. Section III discusses the evidence from the recent surveys of banks sponsored by the IMF and the BAFT-IFSA. Section IV considers factors other than trade finance that contributed to the drop in trade during the crisis. Section V reviews the policies taken by official Export Credit Agencies (ECAs) to mitigate gaps in trade finance. Section VI concludes. Several appendicies provide additional detail on the survey results, background on trade finance institutions, and detailed information on the programs on export credit agencies.

\section{Trade And Financial Market Developments in 2008-09}

8. Global trade entered the financial crisis already unsettled by other developments. The sharp drop in trade in late 2008 came after a period of turmoil in global commodities trade. In 2007 and early 2008 prices of both food and fuel increased sharply, with wheat prices doubling and rice prices almost tripling. Following difficult harvests in Australia and India (among others), several countries banned exports to keep staple food prices lower internally. Fuel prices in 2007 rose around 50 percent, mostly from increased demand, which also affected fertilizer prices (some of which is produced from natural gas), lowering potential agricultural output. Against this backdrop, there were reports that futures contracts were being broken, as the high prices on the spot market more than compensated for having to pay penalties. This led to fears that more widespread market breakdowns would occur, and buyers became more worried about counterparty risk.

9. The disruption to trade finance in late 2008 and early 2009 did not occur in isolation; it took place against a backdrop of the sharp fall in international trade and a broader disruption to global financial markets. The bankruptcy of Lehman Brothers in September 2008 , coming on the heels of lesser financial market failures, exacerbated concerns over counterparty risk in the financial sector caused short-term funding costs to spike, and the turmoil in financial markets spilled over into goods markets. Emerging markets, which had been assumed to have decoupled from developed country growth, were shown to be still dependent on exports. Anecdotal reports of banks refusing to honor trade finance instruments exacerbated this impression. The magnitude and timing of developments in international trade and broader financial markets provides some context for assessing developments in trade finance, and the influence of these markets on trade finance and vice versa.

\section{A. International Trade}

10. International trade had a sharp and globally synchronized fall in the second half of 2008 and early 2009. Exports of advanced, emerging, and developing economies were all growing robustly through mid-2008 before dropping sharply in the second half of 2008 and early 2009 (Figure 1). The reversal was most pronounced for developing economies in which 
the effects of rising partner country demand for commodities until mid-2008 and the subsequent sharp fall in demand were reinforced by a commodity price boom and decline following a roughly similar time path. Although exports of advanced, emerging, and developing economies stabilized in early and mid-2009 and have recovered sharply in late 2009/early 2010 in most major economies (Figure 1a), trade was still much lower in early 2010 than at the mid-2008 peak (Figure 1b).

Figure 1a. Growth Rates of Merchandise Exports 1/

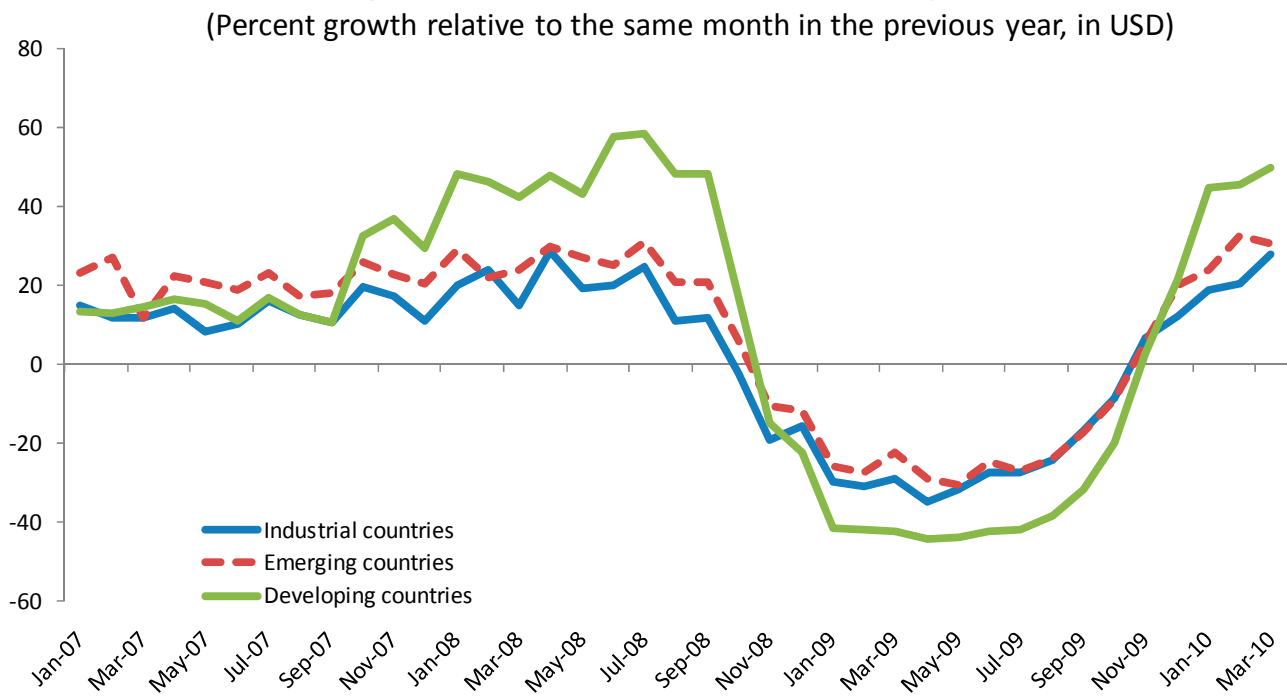

$1 /$ Trade data on industrial, emerging, and developing countries are based on 31, 32, and 20 countries with a few exceptions: for Jan-10 data, 31, 31, and 19 countries are used respectively; for Feb-10 data 31, 29, and 18 countries are used respectively; for Mar-10 data 31, 28, and 15 countries are used respectively. Source: IMF Staff calculations, Haver Analytics, WTO. 


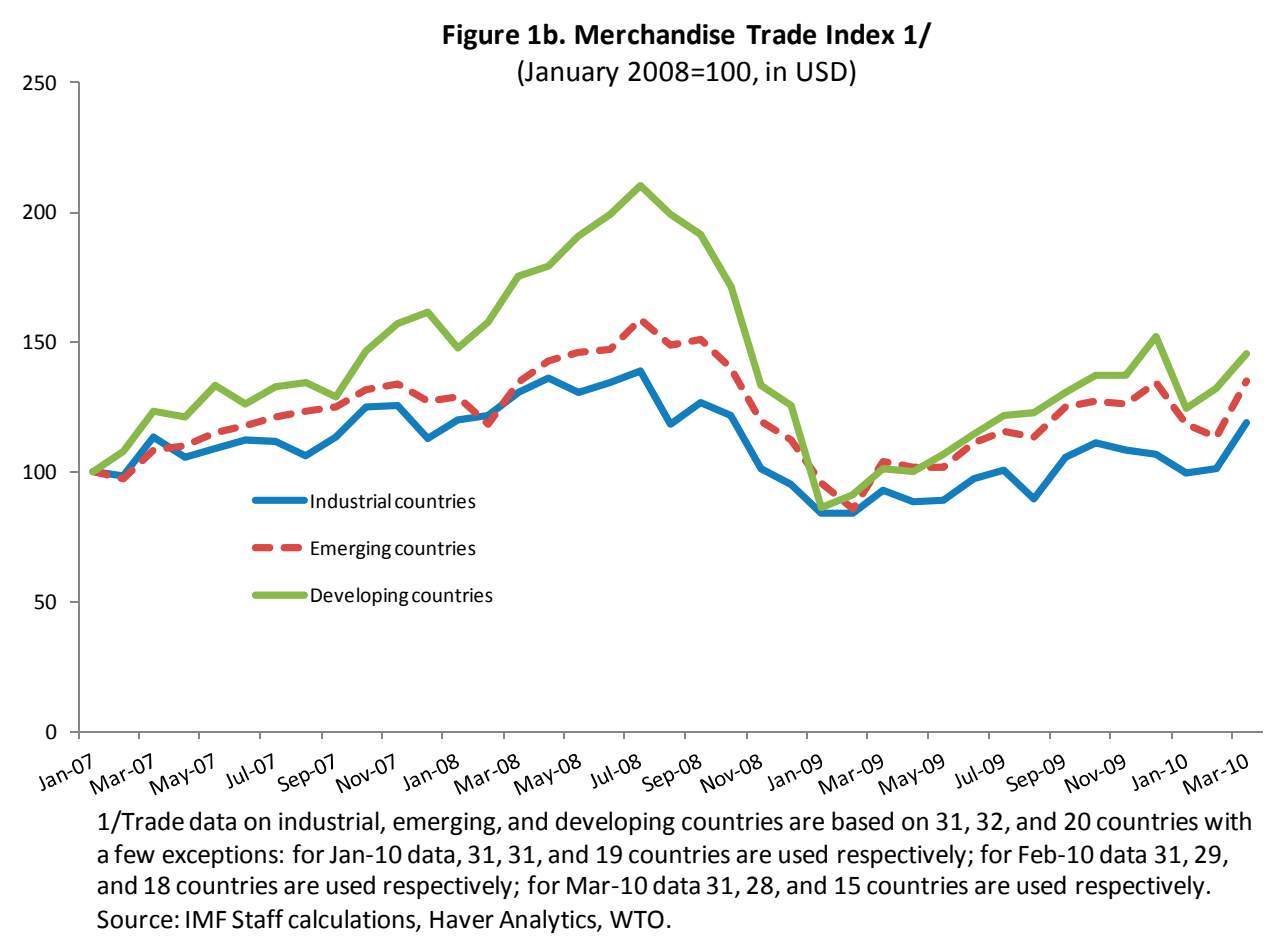

\section{B. Financial Markets}

11. The financial crisis touched off by the September 2008 collapse of Lehman Brothers was manifested in sharply tightened credit conditions in September and October of 2008. Borrowing costs for even the strongest banks rose immediately as LIBOR rates rose by roughly one full percentage point (Figure 2). However, policy rates of major central banks responded quickly and brought LIBOR rates down to pre-Lehman levels within a few weeks and by more than three percentage points from pre-Lehman levels by the second quarter of 2009. 


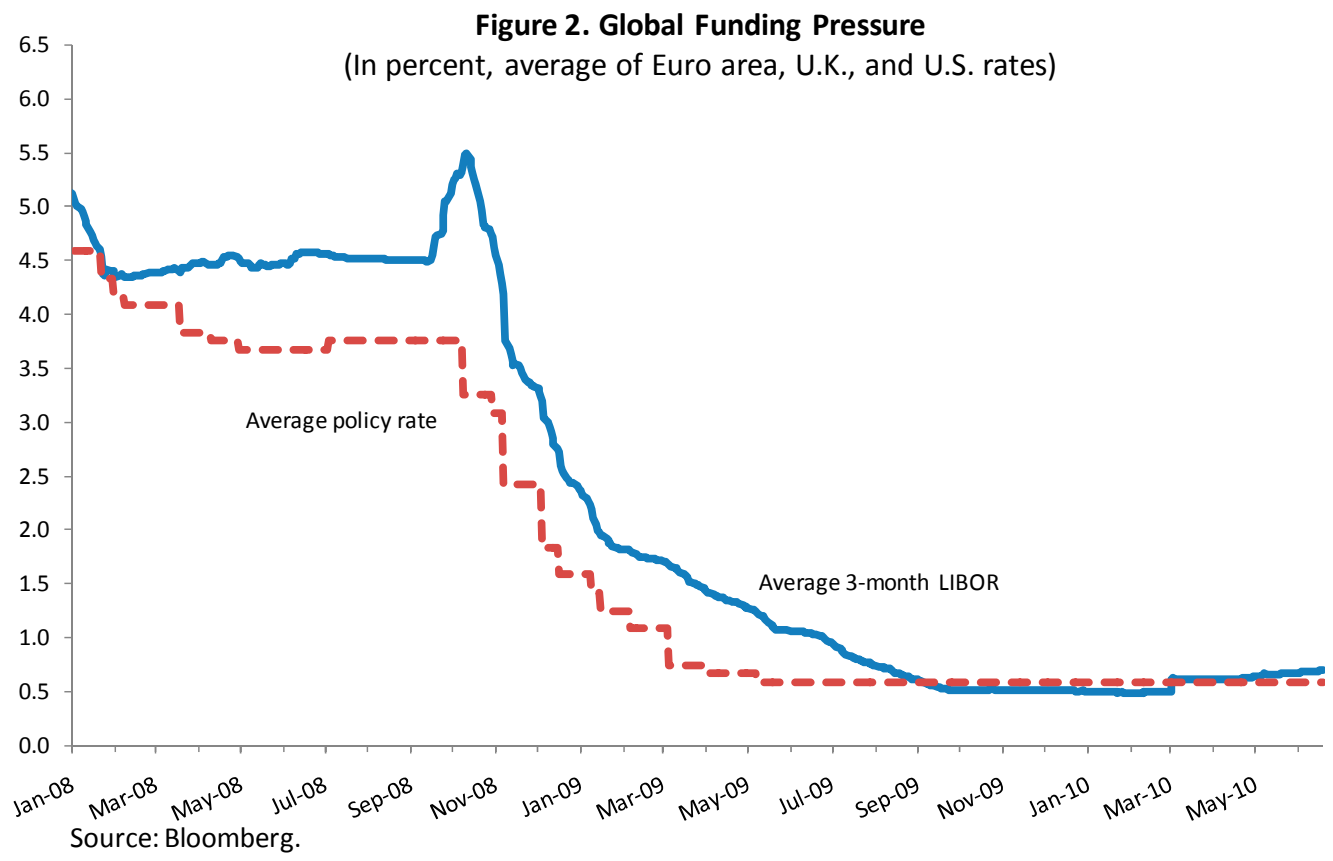

12. The impact of increased cost of funds was spread unevenly across between advanced and emerging markets and among banks and non-banks within those income groups. The interest rate spreads above policy rates rose and fell rapidly in advanced economies (Figure 3a), coming close to pre-crisis levels by January 2009 and dropping below pre-crisis levels by mid-year. Emerging market spreads rose by a much larger margin and fell much more gradually and were still above pre-Lehman levels in the first quarter of 2010 (Figure 3b). 
Figure 3a. 3-Month LIBOR Spreads To OIS

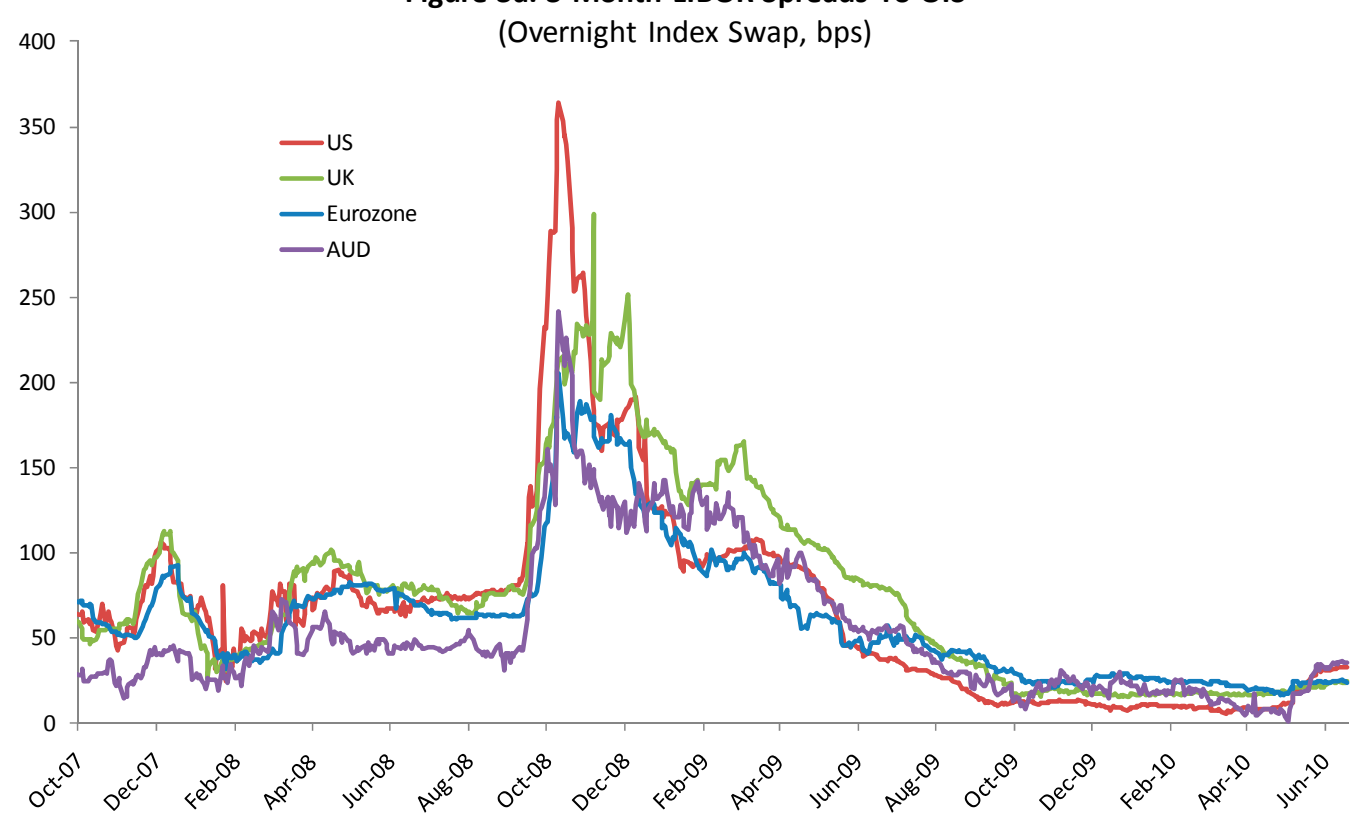

Source: Bloomberg.

Figure 3b. Emerging Markets - External Debt Market Spreads

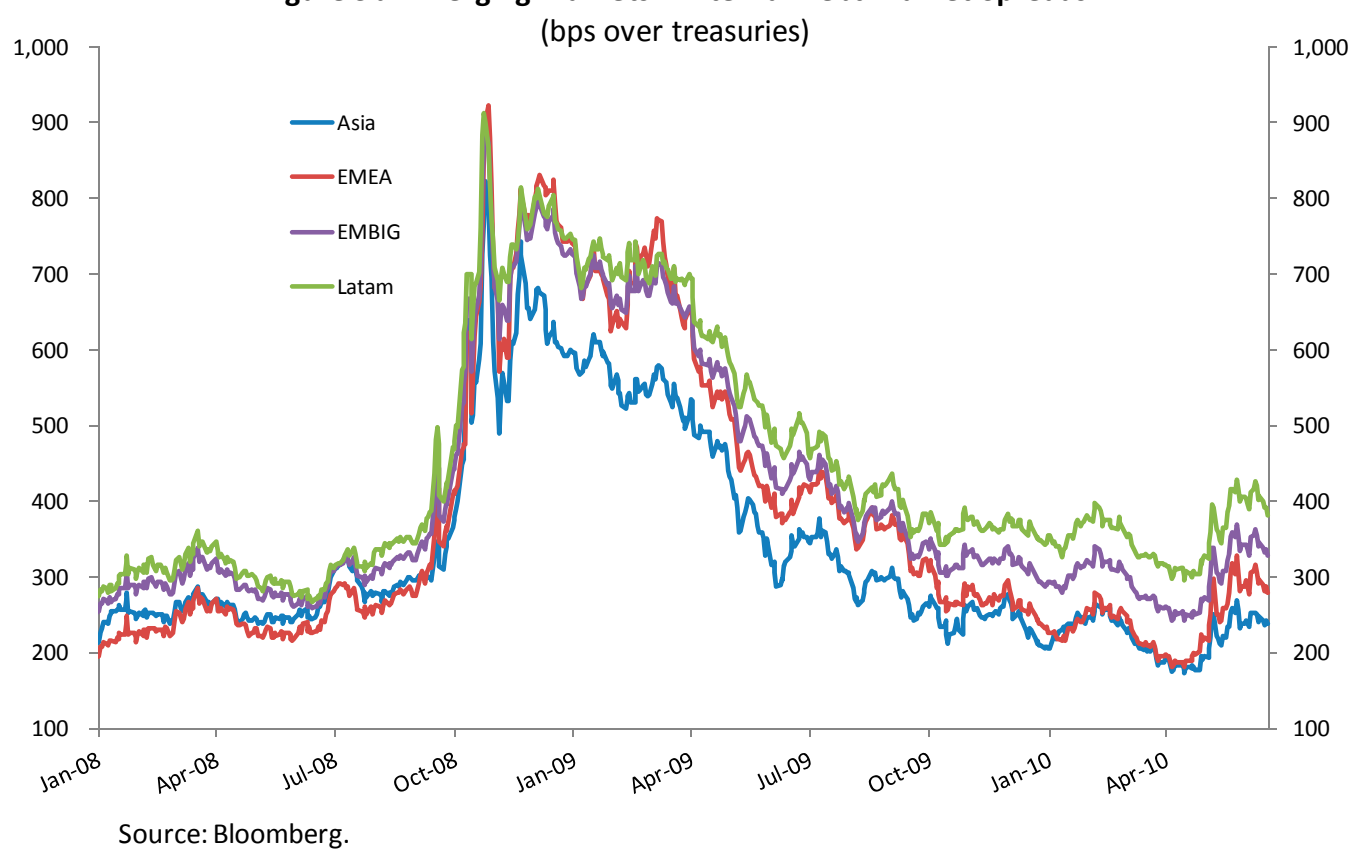

13. The disruption to lending was correlated to the distance between the borrower and the ultimate holder of the debt. Loans to non-financial firms dropped by 14 and 1 percent in the U.S. and the Euro area respectively between 2008 Q4 and 2009 Q3 (Figure 4). However, the decline in commercial paper volumes was much more pronounced. U.S. commercial paper 
volumes fell by 22 and 40 percent for financial and non-financial issuers respectively over the same period (Figure 5). The much sharper decline in traded commercial paper may reflect the widely-reported lack of trust in all securitized debt following the onset of the crisis even though commercial paper is a direct obligation of the borrower.

Figure 4. U.S. and Euro Area Loans

(stocks, Euro and USD billion)

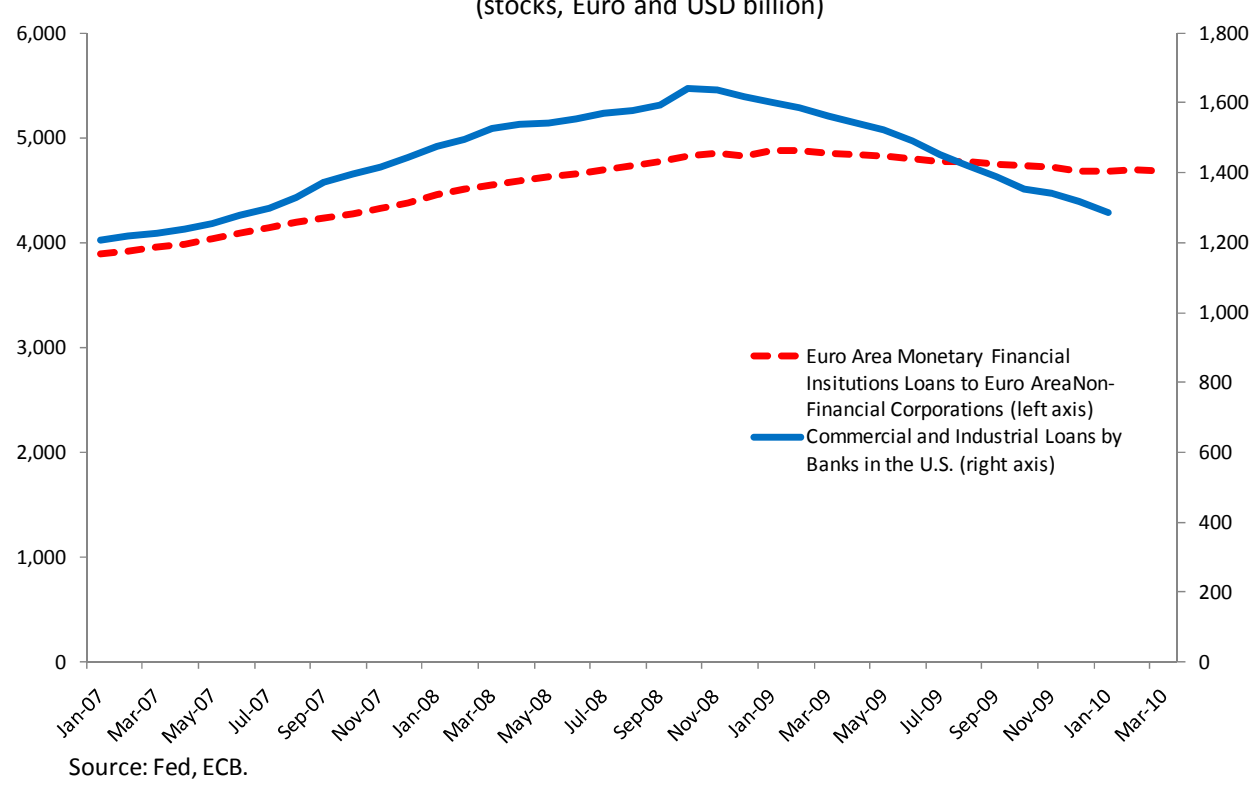

Figure 5. US Commercial Paper: Outstanding Amounts

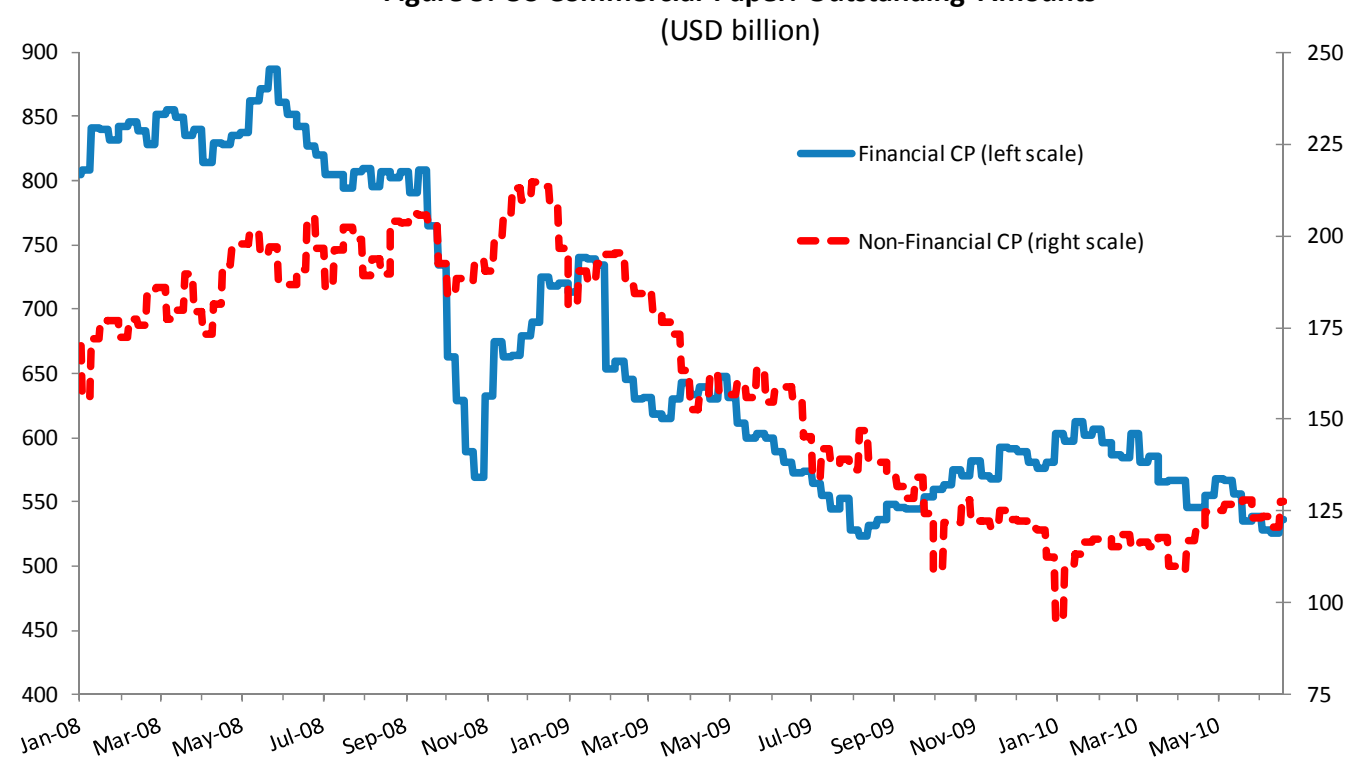

Source: Bloomberg 
14. Secondary markets, in which financial assets are resold by the original lender, were even more severely affected in terms of both volumes and spreads.

- Secondary market volumes for asset-backed securities fell by more than three quarters between mid-2007 peak levels and 2010 Q1; this is an earlier and much more severe decline that for primary market lending (Figure 6).

- Secondary market spreads rose much more than lending spreads in general (Figure 7) with spreads on asset-backed securities rising more than ten-fold to peak at nearly 1000 basis points.

15. A few overall observations can be taken from these trade and financial market data. Merchandise trade fell sharply and at a much faster rate than the decline in GDP during the 2008-09 crisis. However, this is a typical pattern in economic downturns and the decline in both trade and economic activity were well underway before the collapse of Lehman Brothers. Direct lending from banks to final borrowers in advanced economies fell during the crisis, but at a much slower pace than securitized or asset-backed lending.

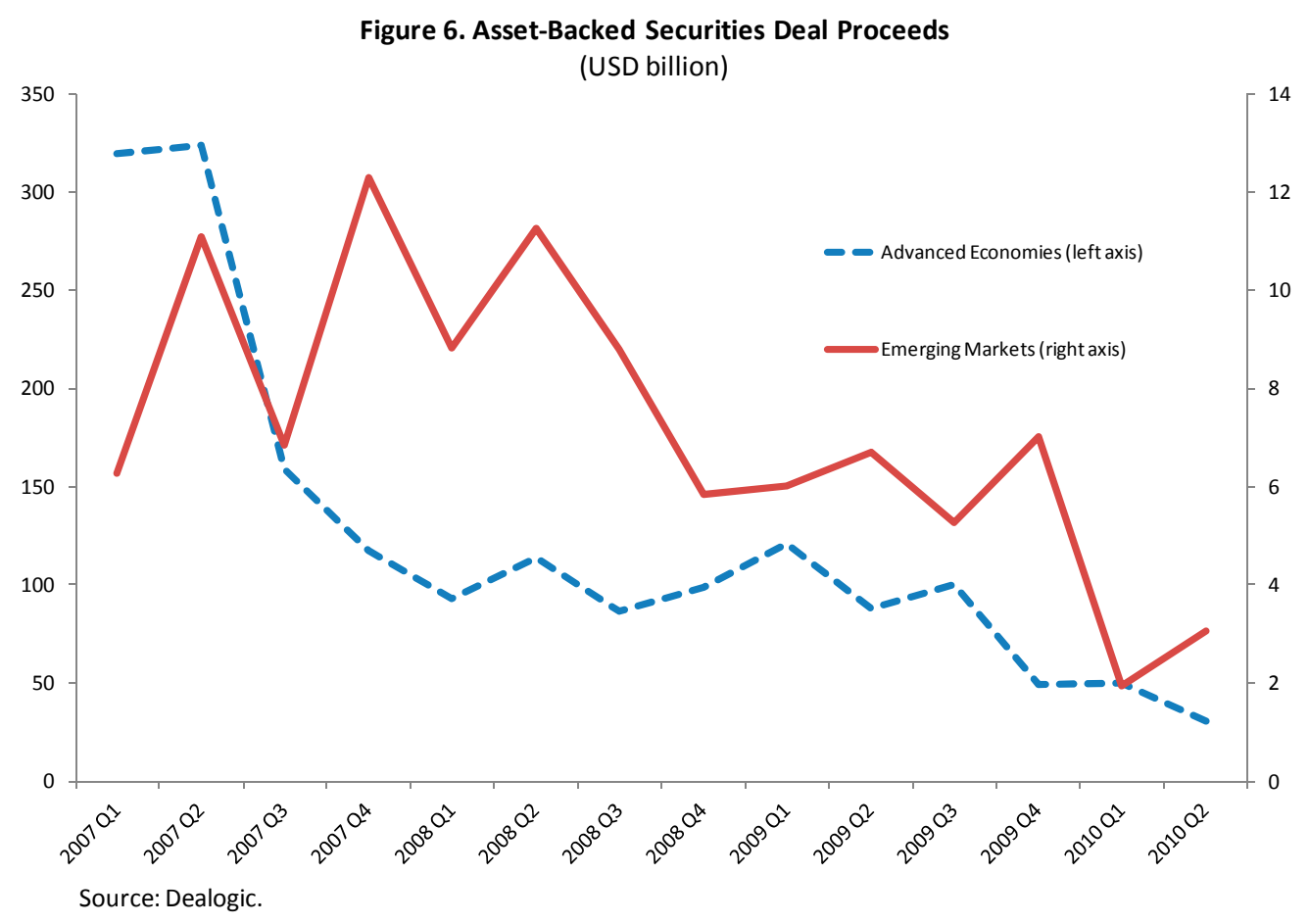


Figure 7. Merril Lynch ABS Master Index, Fixed Rate

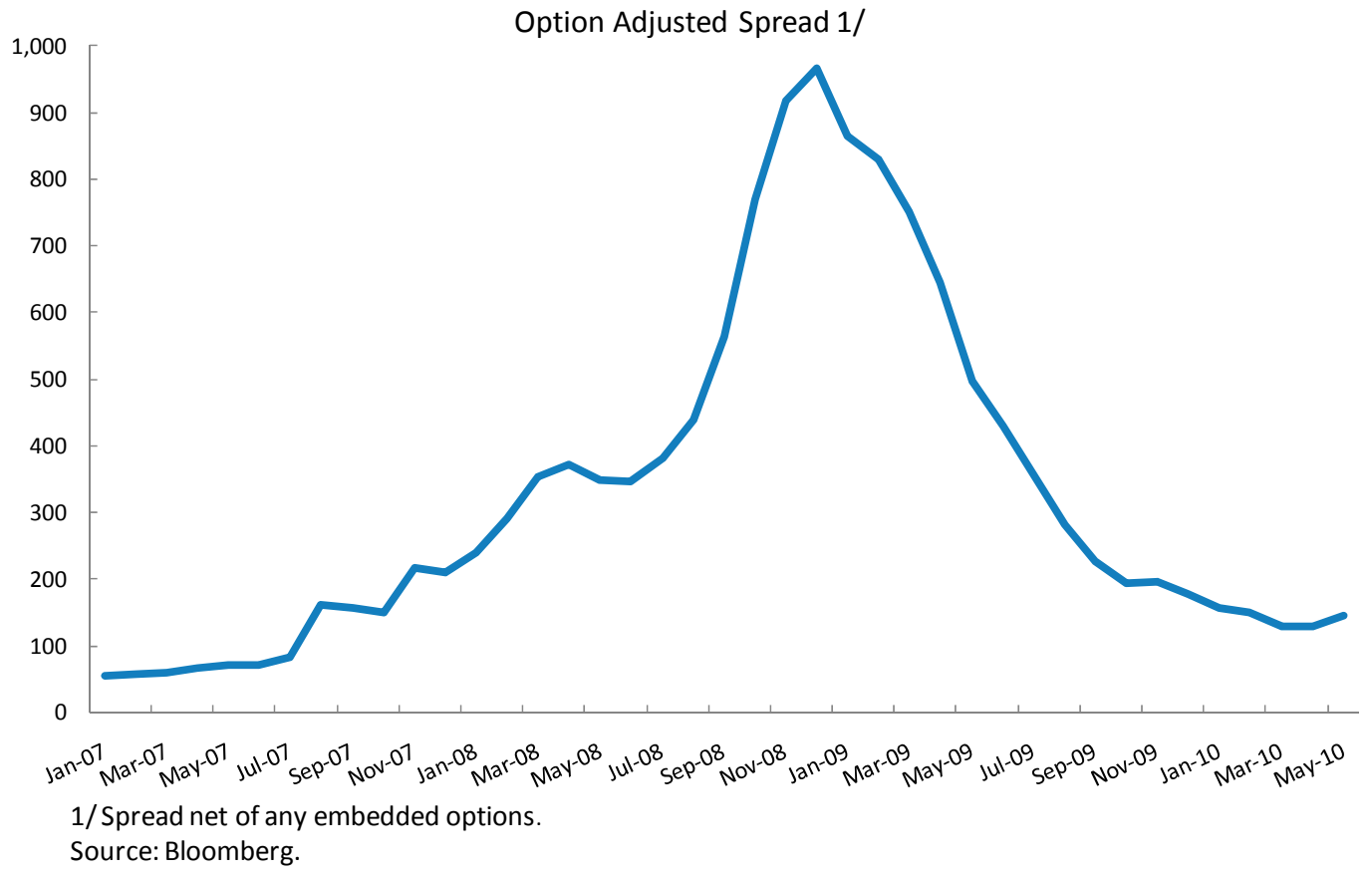

\section{EVIDENCE ON BANK-INTERMEDIATED TrADE FinANCE}

\section{A. Overview}

16. Bank-intermediated trade finance was affected by the crisis along with other financial markets. However, bank-intermediated trade finance largely held up during the crisis. Banks were increasingly cautious with real-sector customers and counterparty banks, and pricing margins often increased. However, these factors were more than offset by an increase in risk aversion on the part of exporters seeking protection from risk. As a result, the share of world trade supported by bank-intermediated trade finance appears to have increased during the crisis. The causes of the increased price and decreased value of trade finance appear to be mostly spillovers from broader financial markets and the recession-induced decline in the value of international trade rather than specific problems in trade finance markets themselves.

17. IMF staff together with the BAFT-IFSA and with the assistance of many other organizations have conducted four surveys of commercial banks to fill gaps in information on commercial bank trade finance since December 2008 (Box 1). The surveys have come from banks of widely varying sizes from banks in countries of all income groups and major geographic regions. Summary data on the characteristics of banks responding to the fourth 
survey are shown in Table $1 .{ }^{4}$ The average bank responding to the survey is active in trade finance in three major regions and has branches in two regions. With the exception of subSaharan Africa, one-fifth or more of the banks were active in each region with coverage of emerging Asia, industrial countries, and Latin America being particularly high.

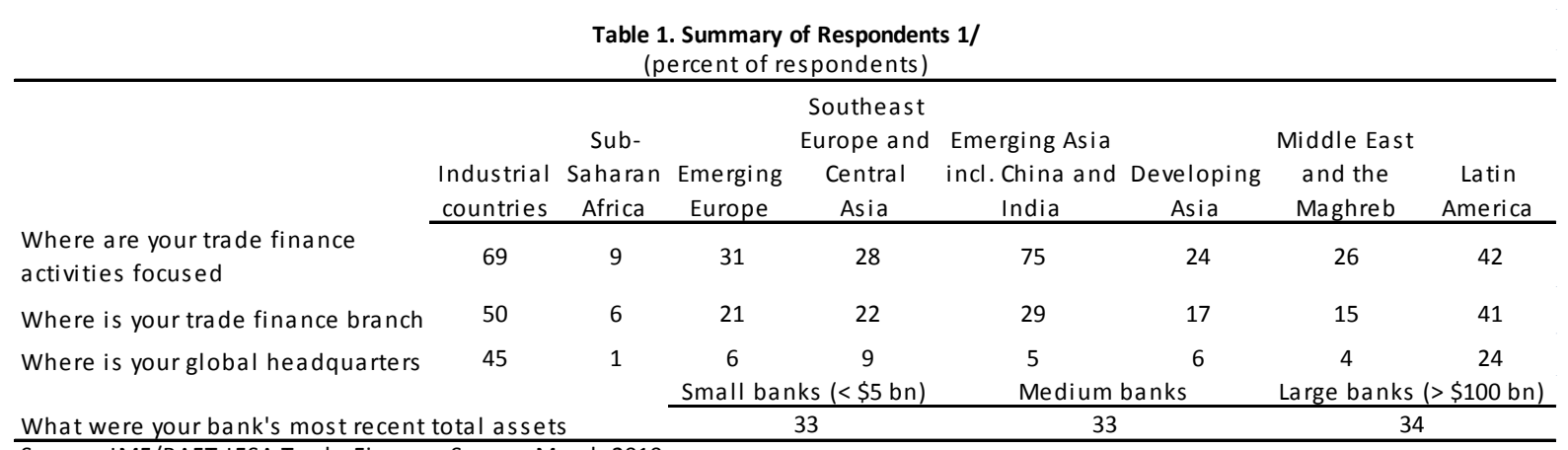

Source: IMF/BAFT-IFSA Trade Finance Survey, March 2010.

$1 /$ The total number of respondents is 100 .

\footnotetext{
${ }^{4}$ The classification of groups of countries used in the survey (Appendix VII) is closely related to the classification used in the winter 2009 WEO. One exception is the inclusion of China and India in Emerging Asia rather than Developing Asia for the trade finance surveys.
} 


\section{Box 1. Why Surveys? IMF/BAFT-IFSA and Other Survey of Banks}

Market conditions for trade finance are difficult to assess because of the absence of data. Bank trade finance is generally based in relationship banking with individual clients, Pricing and availability of bank-intermediated trade finances depends on a complex web of relationships between client, counterparty, and counterparty banks. As such, data are intermingled with proprietary information about bank-client relationships and are difficult to come by. Data on open account and cash-in-advance transactions are similarly tied into individual customer relationships, but data are even harder to come by in the absence of the information clearinghouse role provided with transactions channeled through banks.

The IMF and BAFT-IFSA conducted four surveys of commercial banks between December 2008 and early 2010 to fill these information gaps. All four surveys were designed mostly by IMF staff with the participation of BAFT-IFSA and member banks and direct input from the European Bank for Reconstruction and Development (EBRD) and HSBC. The surveys were distributed primarily by BAFT (BAFT-IFSA for the fourth survey) with the assistance of many cooperating public and private sector organizations. In particular, valuable assistance in further distribution was provided by Federación Latinoamericana de Bancos (FELEBAN). Data were compiled and summarized by FImetrix for the second through fourth surveys. The third and fourth surveys also benefited from collaboration with the Banking Commission of the International Chamber of Commerce (ICC) on survey design and assistance from the Asian Development Bank (ADB) and the EBRD in promoting responses in their regions of operations. The ICC has also conducted its own surveys and published the results (ICC, 2009; ICC, 2010). Although IMF/BAFT -IFSA and ICC surveys have different focuses and different sets of respondents, the results tend to be broadly similar where the survey questions have overlapped. ${ }^{1}$ BAFT-IFSA, the ICC, the IMF, and other institutions involved in earlier surveys are collaborating on new surveys on trade finance market conditions.

${ }^{1}$ The IMF/BAFT-IFSA surveys are designed mostly to support economic analysis of changes in bank trade fiannce. The ICC survey on the other hand has focused more on bank experience with the functioning of legal and procedural aspects of bank experience with trade finance transactions.

\section{B. Value of Trade Finance}

18. The value of trade covered by bank-intermediated trade finance held roughly even rose during the first phase of the crisis (2008 Q4 vs. 2007 Q4) even as the value of trade fell sharply (Table 2 and Figure 8). During the most intense period of the crisis (January 2009 vs. October 2008), trade finance did decline in value by amounts on the order of 10 percent, but the value of merchandise trade fell much more sharply during the same period. In almost all regions and periods through 2009 Q2 the decline in the value of trade finance activities was smaller than in merchandise trade or trade finance value rose even while exports were falling. Although importing and exporting firms can freely choose between open account, bankintermediated trade finance, and cash-in-advance by mutual agreement, the incentives have 
shifted during the crisis. The smaller decline in trade finance presumably reflects a sharply heightened risk aversion of the part of real sector trade participants, and their attempt to address this by shifting some of the transaction risk to the banks. There were signs of recovery in trade, and a more widespread recovery by 2009 Q4 as the growth in the value of trade finance was outstripped by the recovery in the value of merchandise trade in most regions (Table 2 and Figure 9).

Table 2. Changes in Merchandise Exports and Trade Finance: By Groups of Countries (percent growth)

\begin{tabular}{|c|c|c|c|c|c|c|c|c|}
\hline & \multicolumn{2}{|c|}{$2008 Q 4$ vs. $2007 Q 4$} & \multicolumn{2}{|c|}{2009 Jan. vs. 2008 Oct. 1/ } & \multicolumn{2}{|c|}{$2009 Q 2$ vs. $2008 Q 42 /$} & \multicolumn{2}{|c|}{$2009 Q 4$ vs. $2008 Q 4$} \\
\hline & $\begin{array}{l}\text { Goods } \\
\text { Exports }\end{array}$ & $\begin{array}{c}\text { Trade } \\
\text { Finance }\end{array}$ & Goods Exports & Trade Finance & $\begin{array}{l}\text { Goods } \\
\text { Exports }\end{array}$ & $\begin{array}{c}\text { Trade } \\
\text { Finance }\end{array}$ & $\begin{array}{l}\text { Goods } \\
\text { Exports }\end{array}$ & $\begin{array}{c}\text { Trade } \\
\text { Finance }\end{array}$ \\
\hline Industrial Countries & -12.4 & 2.4 & -31.0 & -9.2 & -13.5 & -9.1 & 2.6 & 0.4 \\
\hline Sub-Saharan Africa & -11.2 & 1.4 & -43.2 & -8.1 & -13.2 & -3.0 & 4.9 & 6.5 \\
\hline Emerging Europe & -14.9 & 4.3 & -33.0 & -11.1 & -11.8 & -10.4 & 9.2 & 0.7 \\
\hline Southeast Europe/Central Asia & -8.1 & -4.3 & -54.5 & -13.2 & -30.6 & -7.8 & -3.4 & 0.2 \\
\hline Emerging Asia incl. China and India & -0.4 & 9.1 & -29.0 & -9.7 & -18.0 & 0.0 & 3.8 & 6.1 \\
\hline Developing Asia & 0.4 & 4.2 & -8.8 & -9.1 & 0.8 & -3.8 & 10.1 & 1.8 \\
\hline Middle East and the Maghreb & 1.0 & 2.2 & -20.4 & -5.3 & 1.4 & -5.3 & 11.1 & 4.4 \\
\hline Latin America & -10.4 & 4.8 & -37.4 & -9.5 & -10.4 & -13.7 & 1.9 & 2.2 \\
\hline Overall & -10.3 & $3.43 /$ & -32.2 & $\ldots$ & -14.7 & -7.5 & 2.9 & $2.23 /$ \\
\hline
\end{tabular}

1/ Based on March 2009 survey. Country categories used in this survey are broadly consistent, though not identical to the ones in the next two surveys.

2/ Based on July 2009 survey.

3/ Weighted average of regional changes by level of activity in respective region.

Note: The respondents' samples differ across surveys.

Source: IMF/BAFT-IFSA Trade Finance Surveys (March 2009, July 2009, March 2010), Haver Analytics, IFS, WTO.

Figure 8. Overall Changes in Merchandise Exports and Trade Finance (percent growth)
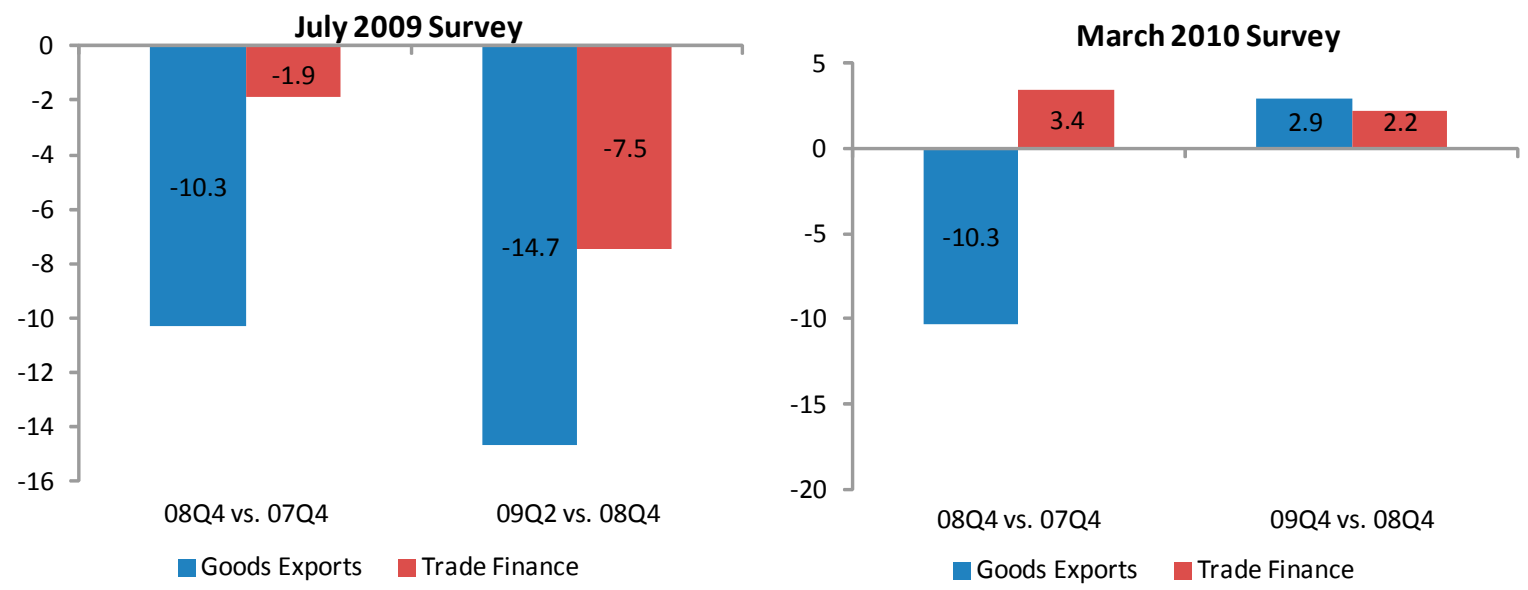

Notes: The overall change in trade finance is computed as the weighted average of regional changes by level of activity in respective region.

The respondents' samples differ across surveys.

Source: IMF/BAFT-IFSA Trade Finance Surveys (July 2009 and March 2010), Haver Analytics, IFS, WTO. 
Figure 9. Changes in Merchandise Exports and Trade Finance: by Groups of Countries (percent growth)
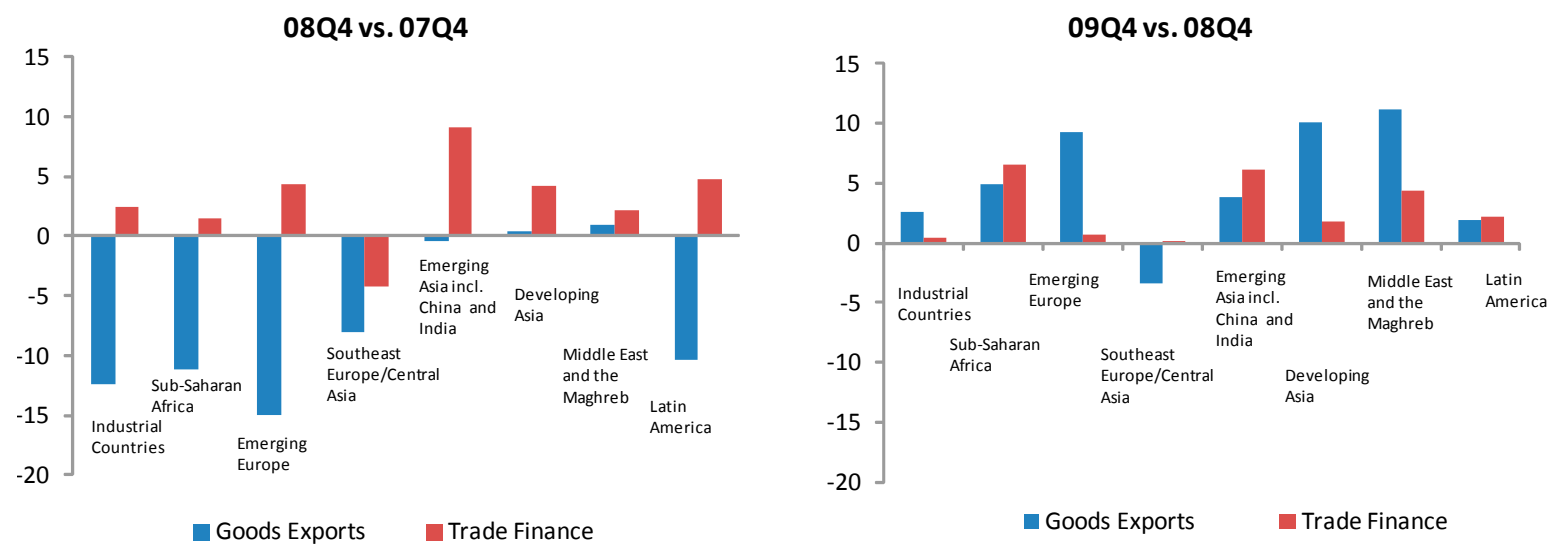

Source: IMF/BAFT-IFSA Trade Finance Survey (March 2010), Haver Analytics, IFS, WTO.

19. The relatively resiliant value of trade finance is also reflected in an increased share of global trade moving from open account to both bank-intermediated trade finance as the crisis progressed. Banks estimate that open account transactions fell below the level of banksupported trade finance in the second quarter of 2009 (Figure 10). These trends appear to reflect increased risk aversion on the part of both banks (increased margins) and nonfinancial corporations (the decline in the share of open account). ${ }^{5}$ The slight decline in bankintermediated trade finance in the most recent period presumably reflects a return toward the long-term trend of a shift to open account as the crisis abated.

\footnotetext{
${ }^{5}$ The third column in Figure 10 is drawn from the third surveys which did not have the same set of respondents and therefore may not be fully comparable with the fourth survey results for the others. However, the survey results for equivalent periods between the two surveys line up quite closely, suggesting a broad consistency in results across these two surveys.
} 


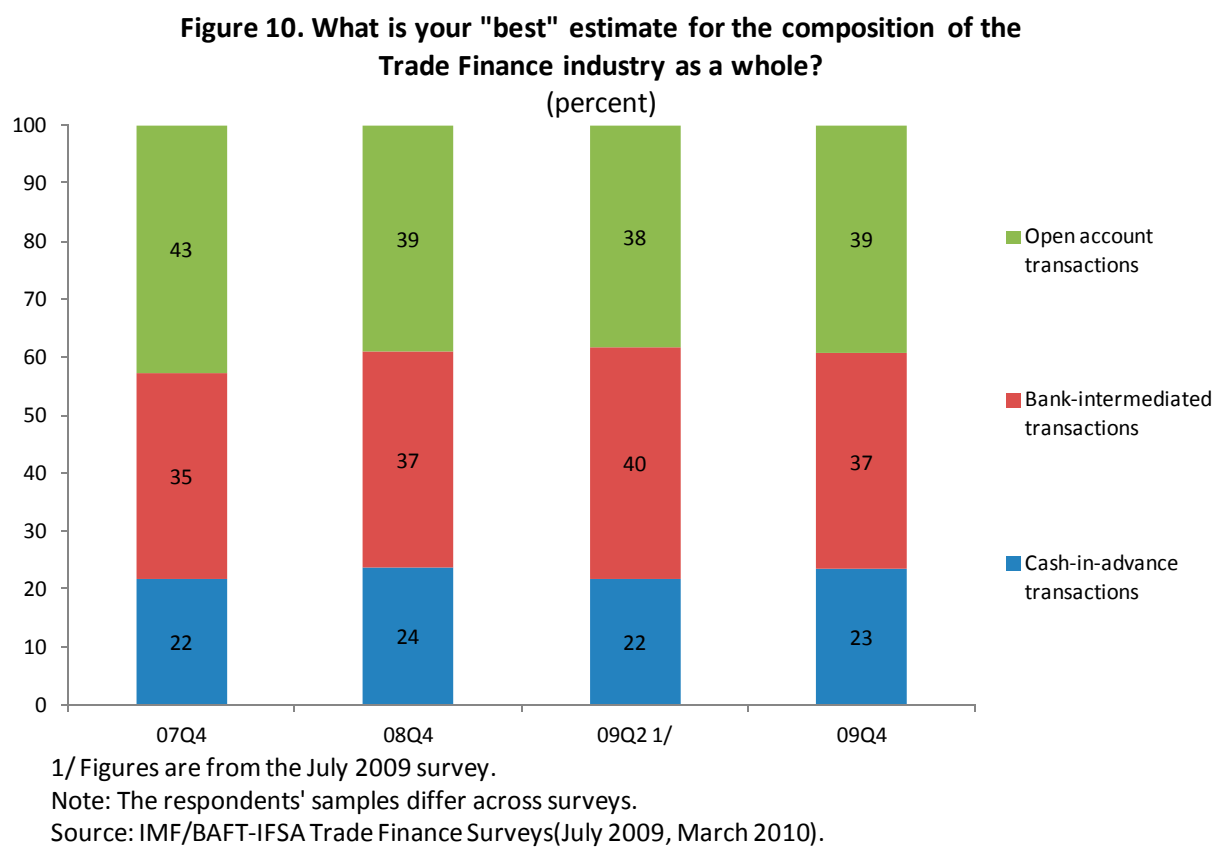

\section{Reasons for the Change in Value of Trade Finance}

20. Banks mostly attributed both the declines and increases in the value of trade finance to demand factors. Of these demand factors, the change in the value of trade was by far the most important with the rise or fall in commodity prices a distant second (Tables 3 and 4). ${ }^{6}$ Supply-side factors such as credit availability at either their own institution or counterparties, and shifts to or from open account or cash-in-advance transactions were factors cited by significant minorities of institutions. Looking across different size classes of banks, credit availability factors seemed to be relatively more important at large banks, presumably reflecting the greater need for deleveraging at some of the largest institutions.

\footnotetext{
${ }^{6}$ Some of the factors cited in the tables cannot be easily assigned to demand or supply (e.g., credit availability from export credit agencies).
} 
Table 3. Reasons for the Decline in Value of Trade Finance 1/ (percent of respondents)

A fall in the demand for trade activities

A fall in the price of transactions (e.g. commodity prices)

Less credit availability at your own institution

Less credit availability at your counterparty banks

A shift towards open account transactions

A shift towards cash-in-advance transactions

A decline in support from Export Credit Agencies

A decline in credit from multilateral institutions

Other reasons

\begin{tabular}{cccc}
$\begin{array}{c}\text { All } \\
\text { banks }\end{array}$ & $\begin{array}{c}\text { Small } \\
\text { banks }\end{array}$ & $\begin{array}{c}\text { Medium } \\
\text { banks }\end{array}$ & Large banks \\
\hline 85 & 81 & 90 & 80 \\
38 & 25 & 24 & 56 \\
30 & 19 & 24 & 40 \\
30 & 6 & 24 & 48 \\
23 & 19 & 33 & 16 \\
21 & 31 & 14 & 20 \\
8 & 0 & 5 & 16 \\
0 & 0 & 0 & 0 \\
18 & 31 & 10 & 16 \\
\hline
\end{tabular}

Source: IMF/BAFT-IFSA Trade Finance Survey, March 2010.

$1 /$ This reflects only the views of the 61 respondents that reported a decline in value of trade finance in at least one geographic region presented and that subsequently marked at least one option for the current question.

Table 4. Reasons for the Increase in Value of Trade Finance 1/ (percent of respondents)

An increase in the demand for trade activities

An increase in the price of transactions (e.g. commodity prices)

More credit availability at your own institution

More credit availability at your counterparty banks

A shift away from open account transactions

A shift away from cash-in-advance transactions

An increase in support from Export Credit Agencies

An increase in credit from multilateral institutions

Other reasons

\begin{tabular}{cccc} 
All & Small & Medium & Large banks \\
\hline 72 & 73 & 77 & 66 \\
34 & 31 & 36 & 34 \\
30 & 31 & 27 & 31 \\
12 & 15 & 14 & 7 \\
28 & 19 & 18 & 41 \\
22 & 35 & 5 & 24 \\
14 & 4 & 18 & 21 \\
14 & 19 & 9 & 14 \\
13 & 12 & 9 & 17 \\
\hline
\end{tabular}

Source: IMF/BAFT-IFSA Trade Finance Survey, March 2010.

1 / This reflects only the views of the 76 respondents that reported an increase in value of trade finance in at least one geographic region presented and that subsequently marked at least one option for the current question.

21. Banks adopted stricter risk management practices in response to higher risks.

(Figure 11 and Table 5). There was greater differentiation based on individual clients, the client business segment (trading, retail, commodities, etc.), and home country. Banks have also limited their own risk through expanded insurance, shorter maturities and stronger covenants, and higher cash deposits or other collateral from clients. Among the relatively few banks that reported a loosening of standards (Table 6), the same factors predominate. Across size classes of banks, large banks were more likely to use greater caution vis-à-vis certain countries than other banks and were also more likely to request confirmations or export credit insurance. On the other end of the size spectrum, small and medium-sized banks were more likely to manage risk with greater collateral or stronger covenants. The 2010 ICC survey also examined SWIFT message data and found evidence of increased risk aversion by banks and 
customers such as refusals to honor letters of credit because of discrepancies in documents (ICC, 2010). ${ }^{7}$

Figure 11. Overall Change in Trade-related Lending Guidelines, 2009Q4 vs. $2008 \mathrm{Q} 4$

(percent of respondents)

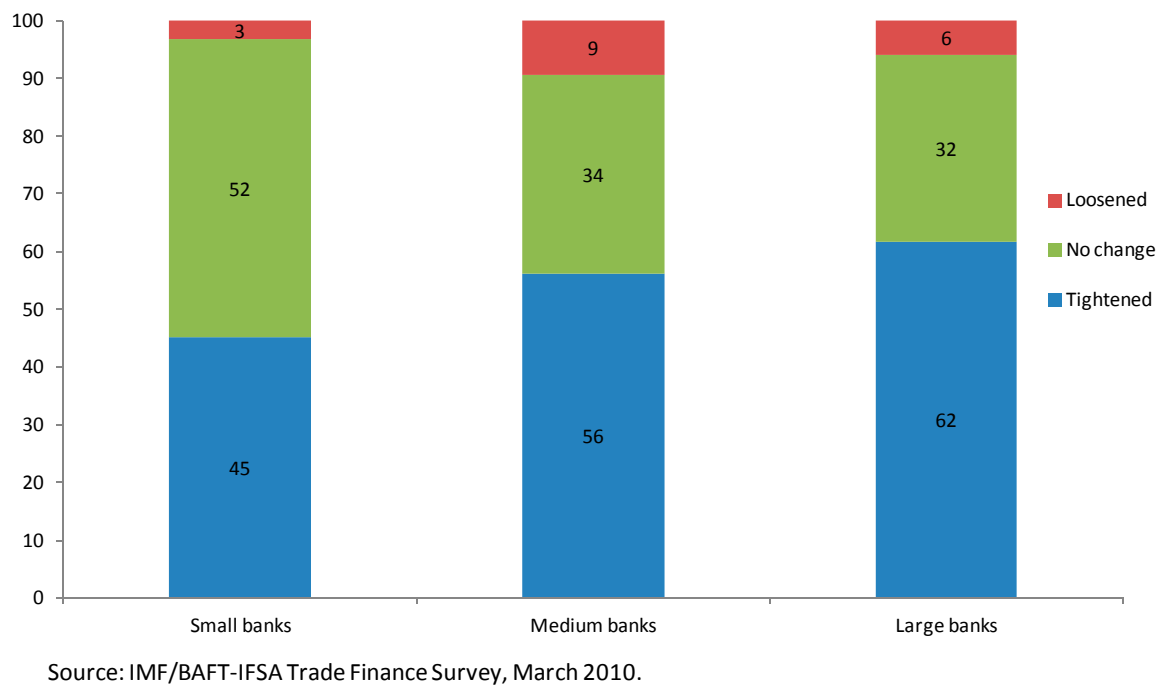

Table 5. Change in Trade-Related Lending Guidelines: Tightening $1 /$ (percent of respondents)

\begin{tabular}{lcccc}
\hline & All banks & $\begin{array}{c}\text { Small } \\
\text { banks }\end{array}$ & $\begin{array}{c}\text { Medium } \\
\text { banks }\end{array}$ & $\begin{array}{c}\text { Large } \\
\text { banks }\end{array}$ \\
\cline { 2 - 5 } Become more cautious with certain sectors & 74 & 71 & 78 & 71 \\
Become more cautious with certain countries & 77 & 57 & 67 & 100 \\
Requested more collaterals (including equity & 62 & 64 & 83 & 43 \\
contributions and cash deposits) & 58 & 57 & 56 & 62 \\
Requested shorter tenors & 47 & 64 & 56 & 29 \\
Requested stronger covenants & 43 & 57 & 33 & 43 \\
Faced more regulatory controls & 42 & 21 & 44 & 52 \\
Requested more DC or LC (including standby and & 28 & 21 & 11 & 48 \\
confirmed LC) & 2 & 0 & 0 & 5 \\
Requested more Export Credit Insurance & & &
\end{tabular}

Source: IMF/BAFT-IFSA Trade Finance Survey, March 2010.

$1 /$ This reflects only the views of the 53 respondents that reported a tightening in trade-related lending guidelines from $2008 \mathrm{Q} 4$ to $2009 \mathrm{Q} 4$ and that subsequently answered this question.

\footnotetext{
${ }^{7}$ The Society for Worldwide Interbank Financial Telecommunications (SWIFT) provides financial messaging services that distinguish, inter alia, between issuance, modification, and refusal of letters of credit. The ICC report analyzed the number of messages in different categories to draw conclusion about trends in bank and real-sector client risk aversion. As the ICC report notes, because SWIFT data provide a count of messages but no information on the size of transactions, they cannot be used to measure the value of different types of trade finance transactions.
} 
Table 6. Change in Trade-Related Lending Guidelines: Loosening 1/ (percent of respondents)

\begin{tabular}{|c|c|c|c|c|}
\hline & All banks & $\begin{array}{l}\text { Small } \\
\text { banks }\end{array}$ & $\begin{array}{l}\text { Medium } \\
\text { banks }\end{array}$ & $\begin{array}{l}\text { Large } \\
\text { banks }\end{array}$ \\
\hline Become less cautious with certain sectors & 83 & 100 & 67 & 100 \\
\hline Become less cautious with certain countries & 50 & 0 & 33 & 100 \\
\hline $\begin{array}{l}\text { Requested fewer collaterals (including equity } \\
\text { contributions and cash deposits) }\end{array}$ & 67 & 100 & 67 & 50 \\
\hline Requested longer tenors & 50 & 100 & 33 & 50 \\
\hline Requested weaker covenants & 50 & 100 & 67 & 0 \\
\hline $\begin{array}{l}\text { Faced fewer regulatory controls } \\
\text { Requested fewer DC or LC (including standby and }\end{array}$ & 17 & 0 & 33 & 0 \\
\hline confirmed LC) & 33 & 0 & 33 & 50 \\
\hline Requested less Export Credit Insurance & 33 & 0 & 0 & 100 \\
\hline Other & 0 & 0 & 0 & 0 \\
\hline
\end{tabular}

Source: IMF/BAFT-IFSA Trade Finance Survey, March 2010.

$1 /$ This reflects only the views of the 6 respondents that reported a loosening in trade-related lending guidelines from 2008Q4 to 2009Q4 and that subsequently asnwered this question.

22. Most banks of all sizes indicated that they could satisfy customer demands for trade finance in the April 2010 survey, although a substantial minority of large banks indicated that they could not (Figure 12). This is consistent with the greater emphasis in credit availability concerns at large banks (Tables 3 and 4) and also with the perception that large banks have been more heavily affected by the need for deleveraging.

Figure 12. Have you been able to satisfy all of your customer needs? (percent of respondents)

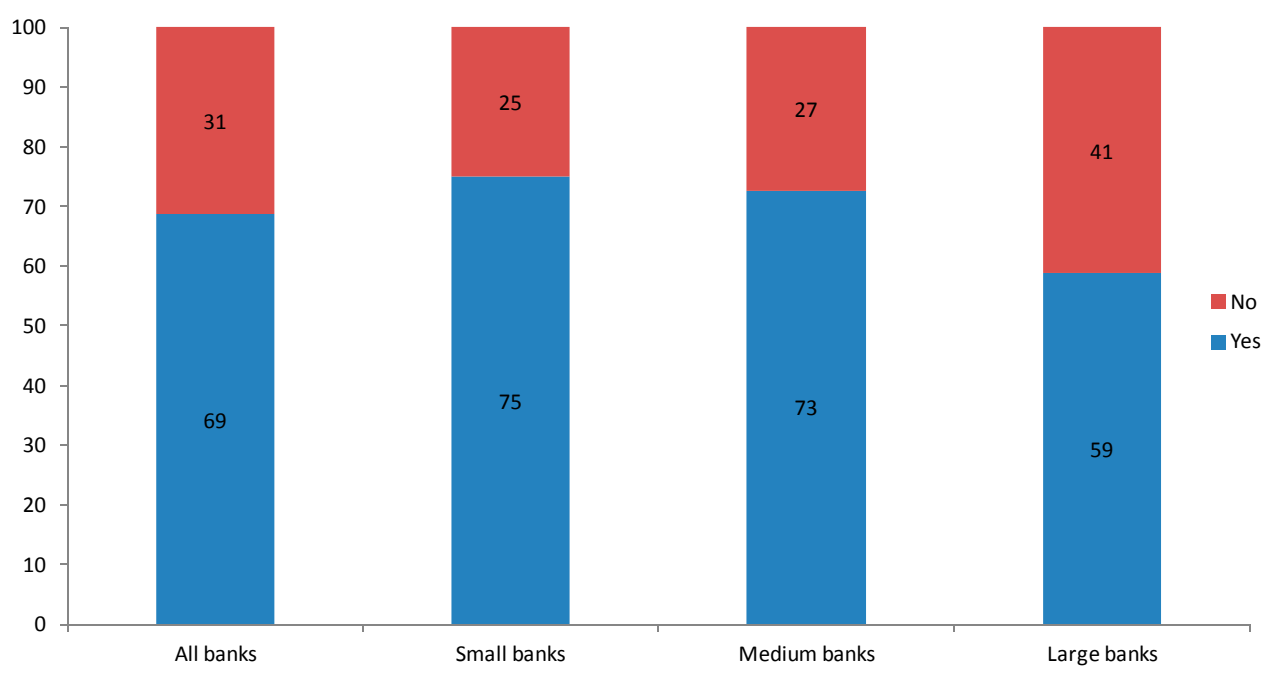

Source: IMF/BAFT-IFSA Trade Finance Survey, March 2010. 
23. Secondary markets in trade-finance receivables do not appear to have been significantly affected by the crisis as far as can be determined by the survey evidence. Most banks reported no change in the use of secondary markets in both 2008 Q4 and 2009 Q4 against the same period a year earlier, and nearly twice as many banks reported increased use of secondary markets as reported decreased use (Figure 13). This is somewhat surprising given the more negative trends in commercial paper and especially asseted-back securities trading in broader financial markets (Figures 4-7). The responses on the use of secondary markets for trade finance were also broadly similar across banks of different sizes (Appendix I, Table I.8; Appendix II, Table II.16).

Figure 13. Have you seen a change in the use of secondary markets? (percent of respondents)

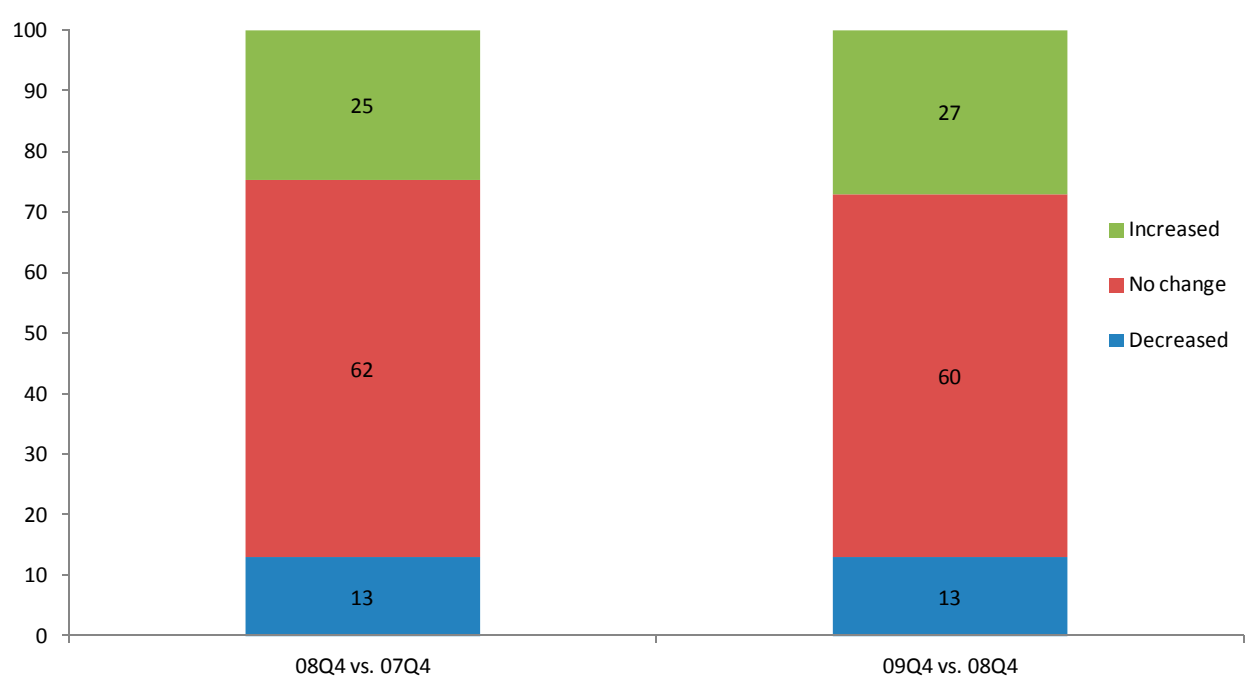

Source: IMF/BAFT-IFSA Trade Finance Survey, March 2010

\section{Bank Pricing and Credit Conditions for Trade Finance}

24. The survey evidence on pricing is also consistent with a demand-driven story in which the decline in trade finance plays no more than a modest role in the decline in merchandise trade. The survey results indicate some increased pricing for trade finance, at least relative to banks' cost of funds (Figures 2 and 3). Other things being equal, this should have reduced the use of bank-intermediated trade finance as a share of trade The increased share of bank-intermediated trade finance in spite of increased pricing also suggests that demand factors such as exporter risk aversion dominated.

25. Average pricing margins for trade finance rose during the crisis, but less than half of the banks increased pricing in any single period. More banks increased pricing than decreased pricing relative to banks' costs of funds. However, a majority of banks either held pricing steady or reduced pricing in the periods 2007 Q4 to 2008 Q4 (Table 7a), 2008 Q4 to 2009 Q2 (Table 7b), and 2008 Q4 to 2009 Q4 (Table 7c). However, because the large banks 
account for a substantial majority of trade finance, average pricing margins for trade finance as a whole almost certainly increased; the largest banks were much more likely to increase pricing and by larger average amounts than the unweighted averages for all banks shown in the tables. These data suggest that pricing pressures eased in the 2009 as the difference in the share of banks reporting increases versus decreases in pricing fell sharply (Figure 14). The average increases in pricing were moderate for most of those banks reporting increases, particularly in 2009 (Figure 15).

Table 7a. Pricing Changes by Size of Bank, $2008 Q 4$ vs. 2007Q4 1/ (percent of respondents)

\begin{tabular}{|c|c|c|c|c|}
\hline & & & & \\
\hline & $\begin{array}{c}\text { All } \\
\text { banks }\end{array}$ & $\begin{array}{l}\text { Small } \\
\text { banks }\end{array}$ & $\begin{array}{c}\text { Medium } \\
\text { banks }\end{array}$ & $\begin{array}{l}\text { Large } \\
\text { banks }\end{array}$ \\
\hline \multicolumn{5}{|l|}{ Letters of credit } \\
\hline Increased & 38 & 23 & 19 & 70 \\
\hline No change & 52 & 63 & 71 & 24 \\
\hline Decreased & 10 & 13 & 10 & 6 \\
\hline Mean change & 31 & 17 & 26 & 50 \\
\hline Median change & 0 & 0 & 0 & 50 \\
\hline \multicolumn{5}{|c|}{ Export credit insurance } \\
\hline Increased & 29 & 22 & 4 & 57 \\
\hline No change & 62 & 61 & 88 & 39 \\
\hline Decreased & 9 & 17 & 8 & 4 \\
\hline Mean change & 14 & 23 & 0 & 21 \\
\hline Median change & 0 & 0 & 0 & 0 \\
\hline \multicolumn{5}{|c|}{ Trade-related lending } \\
\hline Increased & 48 & 41 & 31 & 69 \\
\hline No change & 40 & 44 & 48 & 28 \\
\hline Decreased & 13 & 15 & 21 & 3 \\
\hline Mean change & 48 & 64 & 29 & 53 \\
\hline Median change & 0 & 0 & 0 & 20 \\
\hline \multicolumn{5}{|c|}{ Average across products } \\
\hline Increased & 38 & 29 & 18 & 65 \\
\hline No change & 51 & 56 & 69 & 31 \\
\hline Decreased & 10 & 15 & 13 & 4 \\
\hline Mean change & 31 & 35 & 18 & 41 \\
\hline Median change & 0 & 0 & 0 & 23 \\
\hline
\end{tabular}

Source: IMF/BAFT-IFSA Trade Finance Survey, March 2010.

$1 /$ Mean figures are percentage changes in the pricing margin above bank cost of funds. Mean and median figures do not include responses for which detailed pricing data were not provided. 
Table 7b. Pricing Changes by Size of Bank, 2009 Q2 vs. 2008Q4 1/ (percent of respondents)

\begin{tabular}{|c|c|c|c|c|}
\hline & $\begin{array}{c}\text { All } \\
\text { banks }\end{array}$ & $\begin{array}{l}\text { Small } \\
\text { banks }\end{array}$ & $\begin{array}{c}\text { Medium } \\
\text { banks }\end{array}$ & $\begin{array}{l}\text { Large } \\
\text { banks }\end{array}$ \\
\hline \multicolumn{5}{|l|}{ Letters of credit } \\
\hline Increased & 46 & 38 & 48 & 54 \\
\hline No change & 36 & 41 & 33 & 33 \\
\hline Decreased & 18 & 21 & 19 & 13 \\
\hline Mean change & 23 & 16 & 25 & 31 \\
\hline Median change & 0 & 0 & 0 & 0 \\
\hline \multicolumn{5}{|c|}{ Export credit insurance } \\
\hline Increased & 41 & 32 & 48 & 45 \\
\hline No change & 50 & 60 & 43 & 45 \\
\hline Decreased & 9 & 8 & 9 & 10 \\
\hline Mean change & 19 & 1 & 36 & 18 \\
\hline Median change & 0 & 0 & 0 & 0 \\
\hline \multicolumn{5}{|c|}{ Trade-related lending } \\
\hline Increased & 45 & 33 & 44 & 61 \\
\hline No change & 35 & 45 & 30 & 26 \\
\hline Decreased & 20 & 21 & 26 & 13 \\
\hline Mean change & 28 & 24 & 14 & 57 \\
\hline Median change & 0 & 0 & 0 & 22 \\
\hline \multicolumn{5}{|c|}{ Average across products } \\
\hline Increased & 44 & 35 & 47 & 53 \\
\hline No change & 40 & 49 & 35 & 35 \\
\hline Decreased & 16 & 17 & 18 & 12 \\
\hline Mean change & 23 & 14 & 25 & 35 \\
\hline Median change & 0 & 0 & 0 & 7 \\
\hline
\end{tabular}

Source: IMF/BAFT-IFSA Trade Finance Survey, July 2009.

$1 /$ Mean figures are percentage changes in the pricing margin above bank cost of funds. Mean and median figures do not include responses for which detailed pricing data were not provided. 
Table 7c. Pricing Changes by Size of Bank, 2009 Q4 vs. 2008Q4 1/ (percent of respondents)

\begin{tabular}{|c|c|c|c|c|}
\hline & & & & \\
\hline & $\begin{array}{c}\text { All } \\
\text { banks }\end{array}$ & $\begin{array}{l}\text { Small } \\
\text { banks }\end{array}$ & $\begin{array}{c}\text { Medium } \\
\text { banks }\end{array}$ & $\begin{array}{l}\text { Large } \\
\text { banks }\end{array}$ \\
\hline \multicolumn{5}{|l|}{ Letters of credit } \\
\hline Increased & 40 & 47 & 35 & 39 \\
\hline No change & 36 & 33 & 55 & 21 \\
\hline Decreased & 23 & 20 & 10 & 39 \\
\hline Mean change & 6 & 9 & -5 & 15 \\
\hline Median change & 0 & 0 & 0 & 0 \\
\hline \multicolumn{5}{|c|}{ Export credit insurance } \\
\hline Increased & 32 & 39 & 24 & 32 \\
\hline No change & 49 & 43 & 64 & 39 \\
\hline Decreased & 20 & 17 & 12 & 29 \\
\hline Mean change & 3 & -13 & 5 & 11 \\
\hline Median change & 0 & 0 & 0 & 0 \\
\hline \multicolumn{5}{|c|}{ Trade-related lending } \\
\hline Increased & 47 & 56 & 41 & 44 \\
\hline No change & 23 & 15 & 38 & 16 \\
\hline Decreased & 31 & 30 & 21 & 41 \\
\hline Mean change & 11 & 25 & -11 & 23 \\
\hline Median change & 0 & 0 & 0 & 0 \\
\hline \multicolumn{5}{|c|}{ Average across products } \\
\hline Increased & 40 & 47 & 34 & 38 \\
\hline No change & 36 & 31 & 52 & 25 \\
\hline Decreased & 25 & 22 & 14 & 36 \\
\hline Mean change & 6 & 7 & -4 & 16 \\
\hline Median change & 0 & 0 & 0 & 0 \\
\hline
\end{tabular}

Source: IMF/BAFT-IFSA Trade Finance Survey, March 2010.

$1 /$ Mean figures are percentage changes in the pricing margin above bank cost of funds. Mean and median figures do not include responses for which detailed pricing data were not provided. 
Figure 14. Has the pricing of the following trade instruments been affected by recent developments? (percent of respondents)

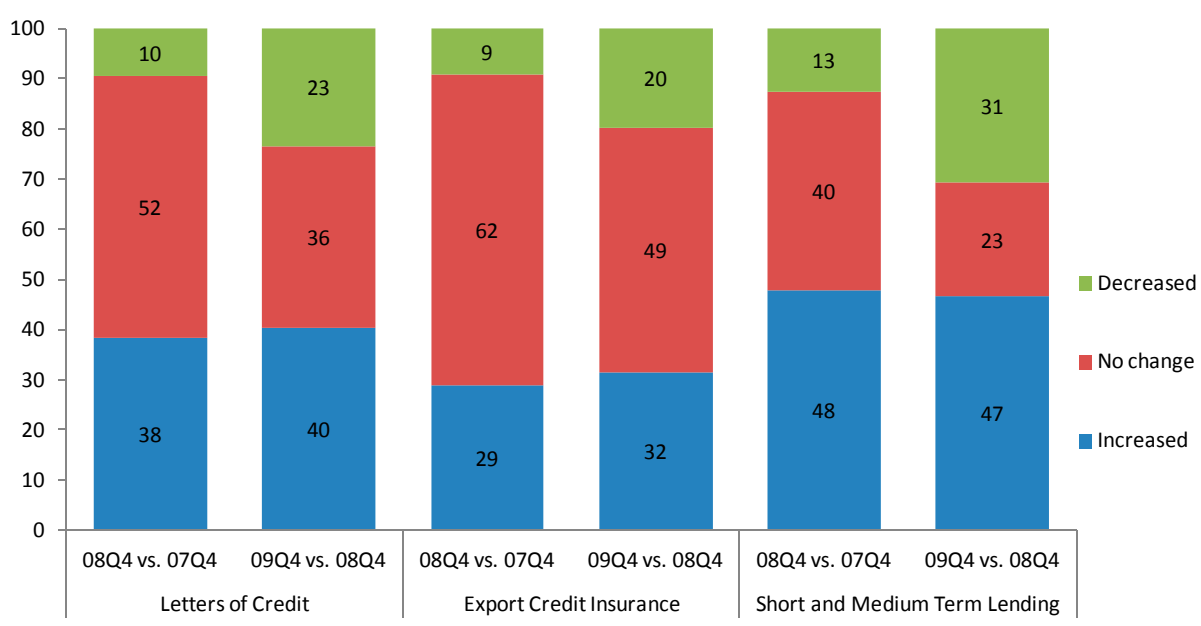

Source: IMF/BAFT-IFSA Trade Finance Survey, March 2010.

Figure 15. Change in Pricing

(bps over cost of funds)

$08 Q 4$ vs. $07 Q 4$

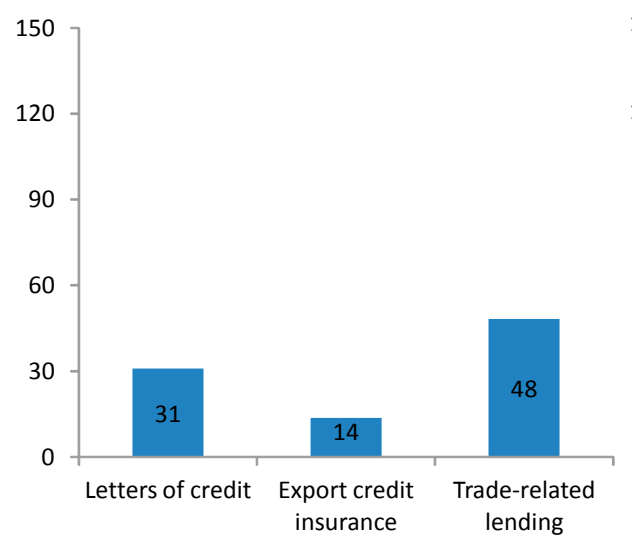

09Q4 vs. $08 Q 4$

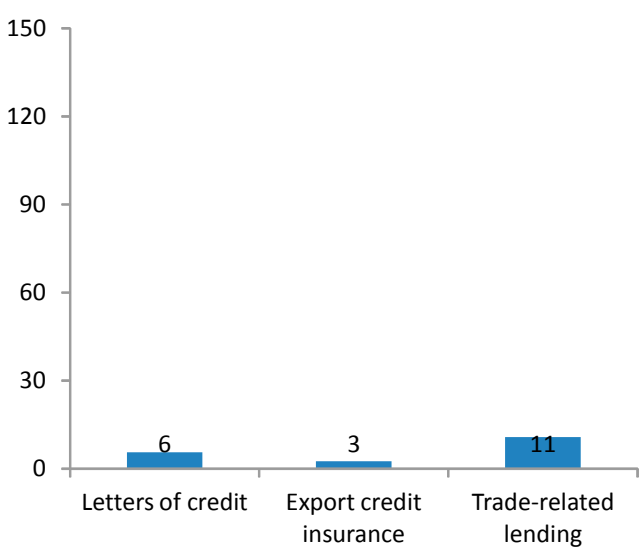

Source: IMF/BAFT-IFSA Trade Finance Survey, March 2010.

26. There is some differentiation in the factors banks see as affecting pricing of trade finance according to the size of the banks. Roughly similar shares of large, medium, and small banks reported increased pricing margins due to increased bank cost of funds, with the share of banks citing this factor falling from about two-thirds in late 2008 to just under half in the first half of 2009. However, increased risk of trade finance lending relative to other bank lines of business was a greater concern for small and medium-sized banks in the latter period (Table 8). Conversely, increased capital requirements were cited more often by large banks. 
Table 8. Reasons for the increase in prices $1 /$

(percent of respondents)

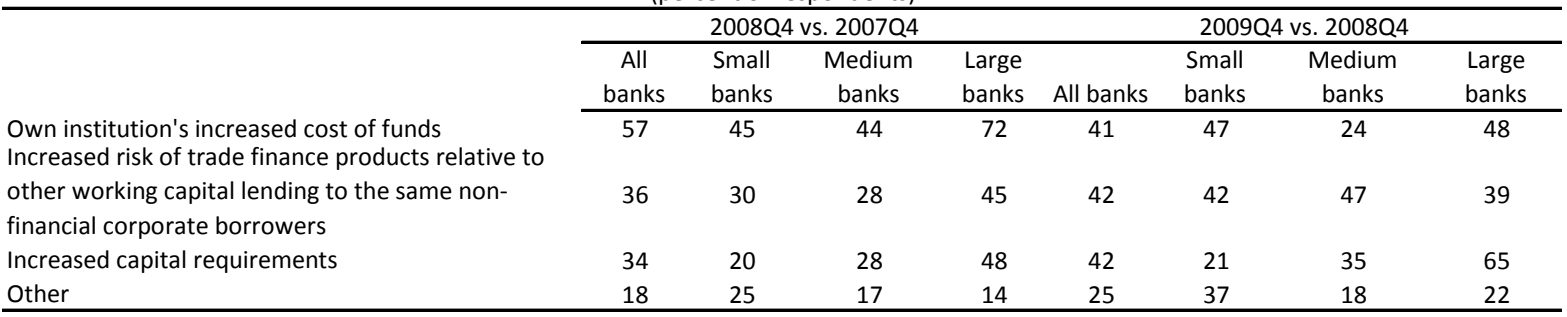

Source: IMF/BAFT-IFSA Trade Finance Survey, March 2010.

$1 /$ This reflects only the views of respondents that reported an increase in pricing and that subsequently answered this question.

27. There was a wide divergence of views on the impact of Basel $\mathrm{II}^{8}$ capital requirements between large and other banks with large banks were also more concerned about the impact of Basel II on their ability to provide trade finance (Table 9). This is consistent with the more frequent citation of increased capital requirements as a factor behind increased pricing margins. Also consistent with the survey results on factors behind increased pricing, no small banks and only a minority of medium-sized banks cited Basel II as having a negative impact on their ability to provide trade finance. Interestingly, a minority of banks of varying size cited Basel II as having a positive impact on their ability to provide trade finance. As with the dispersion in the response of banks on pricing, this may reflect differing initial capital and risk requirements leading to an increase in the relative competitiveness of the more conservative banks once Basel II requirements are in effect.

Table 9. Impact of Basel II on ability to provide trade finance 1/ (percent of respondents)

\begin{tabular}{|c|c|c|c|c|c|c|c|c|}
\hline \multirow[b]{3}{*}{$\begin{array}{l}\text { Not applicable (incl. Basel II has not been } \\
\text { implemented) }\end{array}$} & \multicolumn{4}{|c|}{$2008 Q 4$ vs.2007Q4 } & \multicolumn{4}{|c|}{$2009 Q 4$ vs. 2008 Q4 } \\
\hline & All banks & $\begin{array}{l}\text { Small } \\
\text { banks }\end{array}$ & $\begin{array}{l}\text { Medium } \\
\text { banks }\end{array}$ & $\begin{array}{l}\text { Large } \\
\text { banks }\end{array}$ & All banks & $\begin{array}{l}\text { Small } \\
\text { banks }\end{array}$ & $\begin{array}{l}\text { Medium } \\
\text { banks }\end{array}$ & $\begin{array}{l}\text { Large } \\
\text { banks }\end{array}$ \\
\hline & 17 & 50 & 0 & 14 & 12 & 25 & 0 & 13 \\
\hline No impact & 52 & 50 & 80 & 43 & 42 & 75 & 71 & 20 \\
\hline Positive impact & 9 & 0 & 0 & 14 & 12 & 0 & 14 & 13 \\
\hline Negative impact & 22 & 0 & 20 & 29 & 35 & 0 & 14 & 53 \\
\hline Other & 0 & 0 & 0 & 0 & 0 & 0 & 0 & 0 \\
\hline
\end{tabular}

Source: IMF/BAFT-IFSA Trade Finance Survey, March 2010.

1 / Includes only respondents reporting price increases due to increased capital requirements and that subsequently marked at least one option for the current question.

28. In addition to capital requirements and banks' costs of funds, the probability of default decreased over the course of 2009 (Figure 16). The majority of respondents indicated that there was no change in defaults and net only 13 percent (i.e., the difference between the percentage reporting an increase and the percentage reporting a decrease in defaults) reported

\footnotetext{
${ }^{8}$ The four surveys during 2008-early 2010 covered issues related to the impact of Basel II on trade finance. With acceleration of the Basel III (tentatively set for implementation by end-2012), the on-going survey covers questions related to the impact of Basel III on trade finance industry. Some suggest that the application of credit conversion factor proposed under the Basel III may affect negatively trade finance industry (Auboin, 2010).
} 
an increase in default risk in 2009 against a net of 30 percent between 2007 Q4 and 2008 Q4. However, perceived higher default risks continue to price up the price of credit - among the respondents in the July 2009 survey indicating they had increased prices, 47 percent of respondents identified default risk as a significant force in higher margins, with the increased cost of funds as a leading reason for higher margins (52 percent of respondents) - see Appendix II.

Figure 16. Change in the probability of default (percent of respondents)

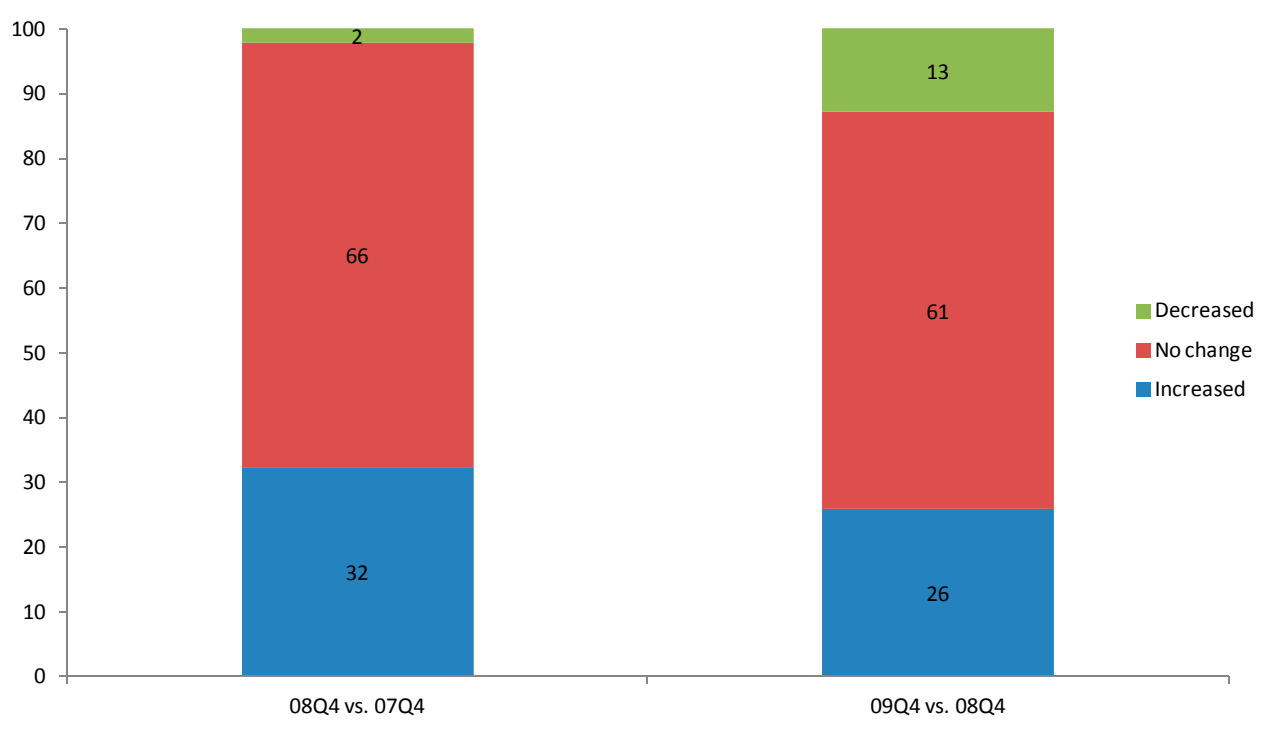

Source: IMF/BAFT-IFSA Trade Finance Survey, March 2010.

29. The increased pricing margins that came with the crisis may be a persistent phenomenon regardless of developments in defaults and Basel II (or Basel III) requirements. Although this is not addressed by the surveys, a widely held view among market participants is that markets are unlikely to return to pre-crisis conditions because trade finance pricing margins were artificially low before the crisis, as was also the case with other types of shortterm financing. This is consistent with the view by banks that trade finance was often a "lossleader" service provided to maintain client relationships, and that banks were putting insufficient capital behind risk in general. In equilibrium, prices may have to be higher, but it is unclear at what level they should settle.

\section{E. Summary of Survey Results}

30. Bank-intermediated trade finance largely held up during the crisis even as it came under several sources of strain. The value of trade finance fell at the peak of the crisis, but it fell by consistently smaller percentages across regions than the decline in exports in the same region. As a result, the share of bank-intermediated trade finance in world trade increased during the crisis. 
31. The increased share of bank-intermediated trade finance came in spite of considerable headwinds.

- Banks supplying trade finace shared the general increase in risk aversion observed in broader financial markets, and they restricted their supply of trade finance to certain countries or sectors and otherwise tightened credit conditions.

- Banks also increased pricing margins driven by both increased perceptions of default risk and higher capital requirements, the latter in part due to Basel II requirements.

- However, the impact of these factors seems to have been more than offset by a parallel increase in risk aversion by real-sector customers as these customers had become increasingly willing to pay banks to absorb risk, even at an increased cost.

- The lower total cost of credit may also have helped to support the value of trade finance as the decline in banks' costs of fund (e.g., LIBOR) more than offset the increased pricing margins for many banks.

\section{OTher FaCtors in The DeCline in Trade}

32. The severe and synchronized collapse in world trade observed in 2008 was unprecedented, and has generated significant attention. Many researchers have posed hypotheses on the causes of this collapse (Baldwin, 2009). They do not all agree on all the points, but a consensus seems to have emerged: the great trade collapse was mostly due to a demand shock. Eaton and others (2010) have shown empirically that a collapse in trade was indeed largely due to a decline in demand for manufactures within an input-output framework with a structural gravity trade model.

\section{A. Trade-Output Relationship}

33. The demand shock was very large, but also was focused on a narrow range of goods, the production of "postpone-able" goods. During the slowdown, consumer durables and investment goods are hardest hit as consumers delayed purchases and firms shelved investment plans. Since these "postpone-able" goods typically comprise a much larger share of trade than GDP or industrial production, trade tends to fall more rapidly than output (Levchenko and others, 2009). In comparison, the decline in GDP-comprised largely of services - was contained (Borchert and Mattoo, 2009). Analogously, trade in services has fallen by less than trade in goods.

34. The surge of global supply chains (manufacturing are now geographically unbundled with various slices of the value-added process being placed in nearby nations) has led to a situation where imported parts are transformed into exported components which are then assembled into final goods to be exported again. The presence of these highly integrated and 
tightly synchronized production networks plays an important role in the nature of the great trade collapse (Bems et al., 2010).

35. Merchandise trade tends to fluctuate much more than proportionately to changes in national income. To estimate trade effects of downturns, Freund (2009) estimated the elasticity of trade to income. The paper also finds that the sensitivity of trade to output has been increasing in recent years, consistent with increasing globalization. Both Freund and Irwin (2002) found that the elasticity of world trade to income grew over time to about about $3 \frac{1}{2}$ in the 1990s. Freund (2009) also found that trade was more responsive to GDP during global downturns than in tranquil times.

\section{B. General Financing Constraints}

36. Along with the rapid decline in trade during the latter half of 2008, shortfalls in the supply of trade finance, possibly acting as a contagion, deepening, and prolonging the recession, were concerns for may of the policymakers. Trade finance has highly vulnerable in times of crisis, as was the case in East Asia in the late 1990s. Wang and Tadesse (2005) found that emerging markets that rely heavily on bank-intermediated trade finance saw a decline in trade finance by as much as 30 to 50 percent in Brazil and Argentina in 2002, by about 50 percent in Korea in 1997-98, and from USD 6 billion to USD 1 billion in Indonesia during the Asian crisis. These declines were also often associated with weak domestic banking system.

37. Access to affordable trade finance has been constrained unevenly in the recent crisis. A World Bank survey of 425 firms and 78 banks report that trade finance has been constrained in some developing regions and for smaller firms (Malouche, 2009). But the impact seems to have varied substantially across the firm size, sectoral activity, and countries' integration into the global economy. For example, based on telephone interviews to companies exporting to Africa in the horticulture and garments sectors, Humphrey (2009) found that most of the African exporters had not (at least up to February-March 2009) experienced significant cutbacks in trade finance availability.

38. Empirical findings of the domestic "trade credit" literature also show that inter-firm transactions (i.e., finance provided at the inter-corporate level for both domestic and foreign customers) were probably constrained. Trade credit is the extension of credit by the seller to the buyer, mostly to finance domestic transactions, and is a substitute of bank loans. Empirical evidence of this literature shows that when access to credit from financial institutions is constrained during a downturn or a recession, less trade credit is extended by the seller to the buyer. ${ }^{9}$

\footnotetext{
${ }^{9}$ Petersen and Rajan (1997), the first study based on U.S. firm-level data, find among other things that firms with less access to credit offer less trade credit. Love et al. (2007), the study based on international micro data
} 
39. Evidence from past banking crises suggests a causal link between reduced credit availability to export sectors and declining trade. Examining sectoral performance in 23 historical banking crises, Iacovone and Zavacka (2009) conclude that banking problems amplify the impact of negative demand shocks on exports, with growth slower in exportoriented sectors reliant on external finance. Amiti and Weinstein (2009) focus on the health of an exporter's bank during the 1992-93 Japanese banking crisis and find that even within a sector, firms whose main bank was more affected by the crisis had weaker export performance. Up to a third of the Japanese export decline in 1992-93 may have been caused by the impact of the banking crisis.

40. Chauffour and Farole (2009) however cautioned against the notion of a large trade finance "gap." They pointed out, as was shown in the earlier part of this paper, that trade finace is not down to nearly the same degree as actual trade flows. They also argue that there are two broad cases that would create a real trade finance gap: (i) there is insufficient supply (i.e., "missing markets") or (ii) it is being supplied at prices that are temporarily too high to meet demand in the market (i.e., "overshooting markets").

\section{Financial Crises and Recessions}

41. Financial crises also contribute to a drop in trade. Thomas (2009) finds that the effect of financial crisis has an additional negative effect on trade, apart from the associated contraction in output. Given that the current crisis includes both financial and real components, this could partially explain the severity of the collapse in trade.

\section{Related-Party Trade}

42. The pattern of the decline in trade across countries and sectors with varying shares of intra-firm trade also shed some light on the role of trade finance in the decline in trade. For example, trade between related parties should not be affected by lower access to trade finance. If subsidiaries of a multinational corporation in different countries are shipping goods between them, there should be no need for bank-intermediated trade finance to mitigate payment risk. The pattern of the trade slowdown across countries and sectors with different shares of intra-firm trade is not consistent with vulnerabilities to trade finance. If anything, there seems to be a postive correlation between the the decline in trade and the share of related-party trade of a country or sector (Table 10).

(a sample of 890 firms in six emerging economies), also find that firms that are financially more vulnerable to crises extend less trade credit to their customers. 
Table 10. Related Party Shares and Trade Growth, Exports to the US (2000 data for shares, $2009 \mathrm{H} 1$ for growth, in percent of value)

\begin{tabular}{lcc}
\hline & Share & Growth Decline \\
\cline { 2 - 3 } Category: & & \\
Cereals and cereal preparations & 0.199 & $-24.3 \%$ \\
Articles of apparel and clothing & 0.156 & $-14.0 \%$ \\
Road vehicles & 0.953 & $-49.2 \%$ \\
Miscellaneous manufactured articles & 0.234 & $-13.0 \%$ \\
Iron and steel & 0.328 & $-16.7 \%$ \\
Telecommunications \& sound recordings & 0.500 & $-21.2 \%$ \\
Petroleum, petroleum products & 0.315 & $-52.2 \%$ \\
Country: & & \\
Brazil & & $-36.9 \%$ \\
China & 0.293 & $-13.4 \%$ \\
Germany & 0.181 & $-35.6 \%$ \\
Japan & 0.647 & $-41.9 \%$ \\
Mexico & 0.743 & $-27.9 \%$ \\
Turkey & 0.661 & $-23.5 \%$ \\
\hline
\end{tabular}

Sources: Bernard, Jensen, Redding, and Schott (2008) for share, US Census for exports.

\section{OfFICIAL SECTOR RESPONSE}

43. National and multilateral institutions have always supported trade finance; however the global crisis led to expansion of their activities. Many multilateral and national institutions increased their capacity for trade finance in line with the call from leaders of G20 countries for sufficient additional capacity to support $\$ 250$ billion of trade over the 20092010 period. ${ }^{10}$ The Communiqué also appealed to national regulators to demonstrate flexibility in the national implementation of Basel II capital requirements for trade finance (G20 Leaders Summit, 2009).

\section{A. Export Credit Agencies}

44. Export credit agencies (ECA) in advanced and major emerging market countries took measures to ensure sufficient capacity to insure their exports to, and in some cases imports from developing and emerging market countries. ${ }^{11}$ According to OECD survey of ECAs in selected OECD countries (OECD, 2009), some ECAs report increase in their portfolios, with

\footnotetext{
${ }^{10}$ G-20 Communiqués, including the communiqué from the April 2009 summit (G20 Leaders' Summit, 2009) can be found at: http://www.g20.org/pub_communiques.aspx and reports to the G-20 from the Trade Finance Experts Group (G20 Trade Finance Experts Group, 2009) can be found at: http://www.g20.org/exp_03.aspx .

${ }^{11}$ More details can be found in Appendix V. While ECAs are often official or semi-official entities, in most cases they are required under WTO and OECD agreements to at least break even over the long run, which in principle should lead to similar decision regarding risk and pricing to those of commercial banks.
} 
new commitments being up by about 30-50 percent. Measures included increased ceilings or capital, higher percentages of cover of the individual export transactions, enhanced support for working capital, and introduction of new products and joint efforts targeting most vulnerable groups of exporters (e.g., SMEs). Some ECAs launched consulting and advisory services, free credit assessments, and programs aimed at facilitation of regulatory environment, etc. Other ECAs enhanced their international cooperation by entering into bilateral agreements with ECAs of their major trading partners.

45. ECA coverage of trade has increased because of increased use of existing ECA programs and new program or expanded limits introduced in the context of the crisis. Data from Berne Union shows that ECAs' share of world exports has increased from about 8 percent during 2005-2008 to slightly above 9 in 2009 (Figure 17). This one-eight increase in share is similar in magnitude to the increase in bank-intermediated trade finance and presumably reflects the same factors of increased risk aversion by non-financial firms. This suggests that ECAs may have played an important role in cushioning the downturn. They may also have played an important signaling role by reassuring the private sector that official institutions stand ready to back up at difficult times.

Figure 17. Share of World Exports of Goods Covered by Berne Union Members, short-term

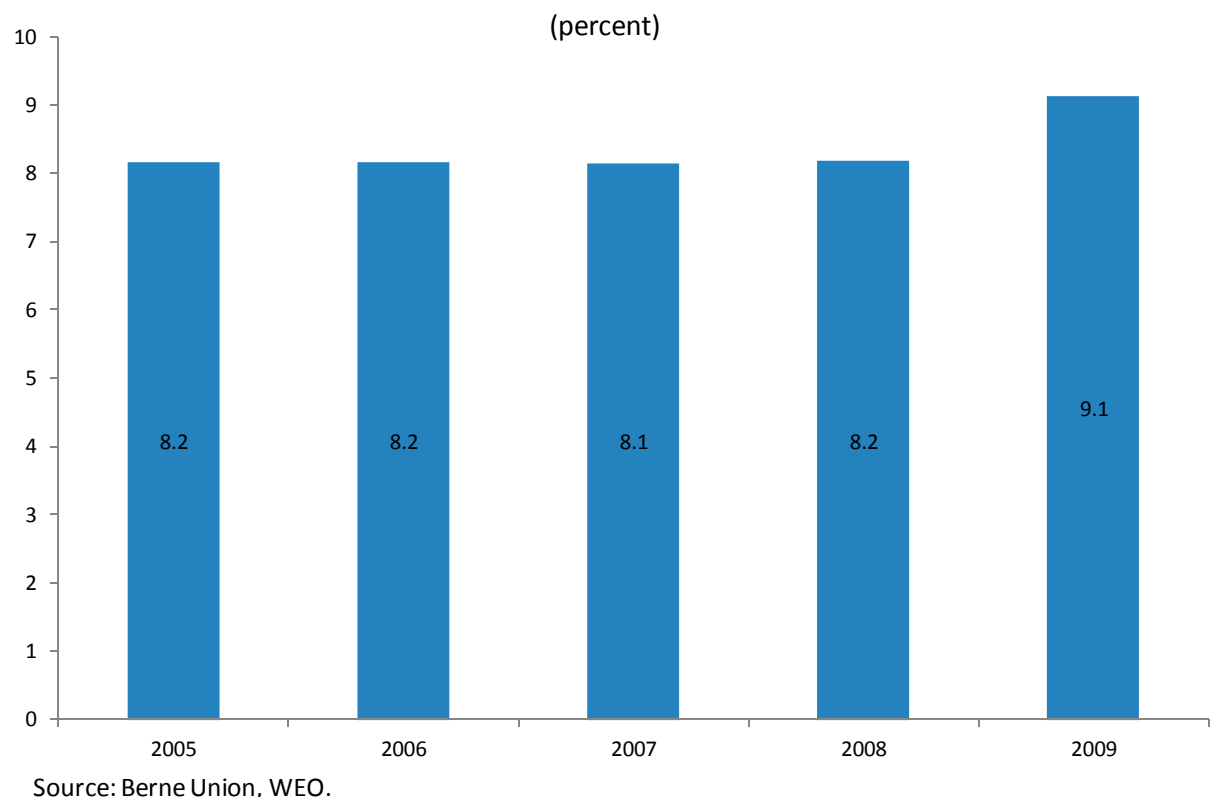




\section{B. Multilateral Development Banks}

46. MDBs acted with variety of programs and measures aimed at facilitation of trade finance. ${ }^{12}$ Indeed, the official sector reponses were well received by commercial banks (Figure 18). These programs and measures were further enhanced in the context of G-20 support of trade finance. They clearly stated the support of G-20 to MDBs in their efforts to “... leverage private capital more effectively, including through the use of guarantees, bond insurance and bridging finance." The G-20 also supported the creation of a Global Trade Liquidity Pool (details in Appendix VI). In the context of the response to global crisis, the Trade Finance Facilitation Program of Inter-American Development Bank was enhanced from $\$ 400$ million to $\$ 1$ billion. The commitments to facilitate trade finance included but were not limited to: support through guarantees, lines of credit, bond instruments guaranteed by the future flows of trade, risk mitigating instruments against commercial and political risks associated with international trade in selected countries. While the increase in MDB capacity is much smaller than the increase in ECA capacity, their focus on developing economies exports as well as imports fills and important gap in the expansion of official sector trade finance capacity.

Figure 18. How do you view the official sector response? (percent of respondents)

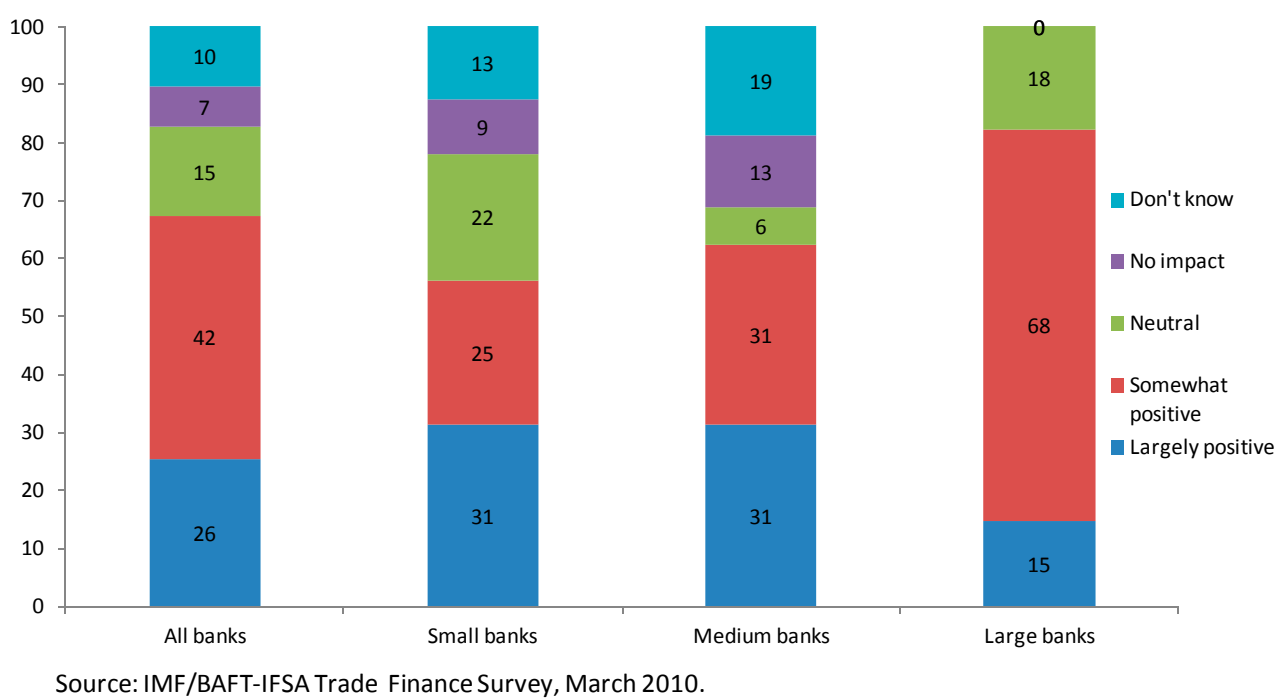

\footnotetext{
${ }^{12}$ Appendix VI covers details of the response by MDBs, including programs, instruments, total amount of the packages and modifications responding to G-20 Communiqués (Declaration on Delivering Resources through the International Financial Institutions"-London, 2 April 2009 - http://www.g20.org/pub communiques.aspx ).
} 


\section{Box 2. The Response of MDBs to the Decline in Trade Finance}

\section{European Bank for Reconstruction and Development (EBRD)}

In response to the global crisis in 2009, the budget of EBRD's Trade Facilitation Program (TFP) was enhanced from $€ 800$ million to $€ 1.5$ billion to mitigate the impact of the crisis and boost trade in member countries. The EBRD's TFP promotes foreign trade with Central and Eastern Europe and the Commonwealth of Independent States.

\section{Asian Development Bank (ADB)}

In response to the global crisis, on 31 March 2009, the ADB expanded its Trade Finance Facilitation Program (TFFP), increasing its overall exposure limit to US\$1 billion from an initial US\$150 million. By the end of 2009, total TFFP exposure reached over US\$700 million, exceeding the US\$500 million target set for 2009.

\section{Inter-American Development Bank (IDB)}

In 2009, the IDB's Trade Finance Facilitation Program (TFFP) was enhanced from US\$400 million to US\$1 billion. The TFFP currently comprises a network of 198 Confirming Banks from 70 different international banking groups, and 41 Issuing Banks in 15 Latin American and Caribbean countries, with US\$756 million in approved credit lines.

\section{African Development Bank (AfDB)}

In 2009, the AfDB established the Trade Finance Initiative of US\$1 billion, aimed at pooling resources to help member countries cope with the global crisis.

\section{International Finance Corporation (IFC)}

In response to the global crisis, IFC has doubled its existing trade finance program to US\$3 billion and worked with governments, private sector and international finance institutions to launch the Global Trade Liquidity Program (GTLP).GTLP began its operations in May 2009, with targeted commitments of US\$4 billion from public sector sources. The program aims at supporting up to US $\$ 50$ billion of trade in three years. The program works through global and regional banks to extend trade finance to importers and exporters in developing countries. 


\section{CONCLUDing Remarks}

47. The suddenness of the drop in trade in late 2008 coupled with the recent shocks to the financial system led to concerns that a collapse in trade finance was causing broader disruptions. The parallels between the markets - lack of liquidity in markets, the role of emerging markets, and worries about counterparty risks in a changing environment - all help explain why there was so much worry initially. However, demand factors played the most important role, prompt action by the G-20 and ECAs likely eased pricing pressures, and helped keep trade flowing during the worst of the disruptions.

48. Research indicates that continuing tight financing conditions can constrain growth, hampering rebalancing according to macro factors. On the other hand, markets are unlikely to return to pre-crisis conditions anytime soon. If trade financing costs were artificially low before the crisis along with other types of short-term financing, prices will have to be higher in a sustainable equilibrium. There may also be a shift in the types of banks that provide trade finance. As was seen during 2008 and 2009, small and large banks reacted differently to the shock, and have different capacity to respond. 


\section{REFERENCES}

Amiti, M., and D.E. Weinstein, 2009, "Exports and Financial Shocks," NBER Working Paper 15556 (Cambridge, Massachusetts: National Bureau of Economic Research).

Auboin, M., 2010, "International Regulation and Treatment of Trade Finance: What Are the Issues?” Staff Working Paper ERSD-2010-09 (Geneva: World Trade Organization).

Baldwin, Richard, "The Great Trade Collapse: What Caused It and What Does It Mean?" in Richard Baldwin, eds., The Great Trade Collapse: Causes, Consequences and Prospects, VoxEU.org, Nov 27, 2009.

Bems, R., R. C. Johnson, and K. Yi, 2010, "Demand Spillovers and the Collapse of Trade in the Global Recession,” IMF Working Paper 10/142 (Washington: International Monetary Fund).

Bernard, A., J. B. Jensen, S. Redding, and P. Schott, 2008, "Intra-Firm Trade and Product Contractibility," Unpublished Manuscript.

Borchert, I., and A. Mattoo, 2009, "The Crisis-Resilience of Services Trade," World Bank Policy Research Working Paper 4917, Washington.

Chauffour, J. P., and T. Farole, 2009, "Trade Finance in Crisis: Market Adjustment or Market Failure?” World Bank Policy Research Working Paper 5003.

Eaton J., S. Kortum, B. Neiman, and J. Romalis, 2010, "Trade and the Global Recession," Unpublished Manuscript, University of Chicago.

Food and Agriculture Organization, 2010, Food Outlook: 2010-2019, June, Rome.

Freund, C., 2009, “The Trade Response to Global Downturns: Historical Evidence,” World Bank Policy Research Working Paper 5015, Washington.

G20 Leaders' Summit, 2009, “G20 Leaders, Leaders Statement - The Global Plan for Recovery and Reform - London, 2 April 2009," http://www.g20.org.

G20 Trade Finance Experts Group, 2009, "G20 Trade Finance Experts Group August Report US-UK Chair's Recommendations for Finance Ministers," August 2009," http://www.g20.org/exp 03.aspx .

Humphrey, J. 2009, “Are Exporters in Africa Facing Reduced Availability of Trade Finance," (Brighton: Institute of Development Studies).

Iacovone, L., and V. Zavacka, 2009, "Banking Crises and Exports: Lessons from the Past," World Bank Policy Research Working Paper 5016, Washington.

ICC, 2009, "Rethinking Trade Finance 2009: An ICC Global Survey," Paris.

_ 2010, "Rethinking Trade Finance 2010: An ICC Global Survey," Paris.

IMF, 2003, "Trade Finance in Financial Crises: Assessment of Key Issues," Washington. , 2008, Global Financial Stability Report, October, Washington. , 2008, "Food and Fuel Prices - Recent Developments, Macroeconomic Impact, and Policy Responses," Washington. , 2009, Global Financial Stability Report, April, Washington.

Irwin, D., 2002. "Long-Run Trends in World Trade and Income", World Trade Review, 1:1, p. 89-100.

Levchenko, Andrei A., Logan Lewis, and Linda L. Tesar, 2009, “The Collapse of International Trade during the 2008-2009 Crisis: In Search of the Smoking Gun," University of Michigan International Economics Discussion Paper 592, Ann Arbor, Michigan. 
Love. I., Preve, L.A., V. Sarria-Allende, 2007, "Trade Credit and Bank Credit: Evidence from Recent Financial Crises," Journal of Financial Economics 83, pp.453-69.

Malouche, M., 2009, "Trade and Trade Finance Developments in 14 Developing Countries Post September 2008: A World Bank Survey," World Bank Policy Research Working Paper 5138, Washington.

OECD, 2009, "Officially Supported Export Credits and the Financial Crisis: Measures Taken at the National Level by the Participants to the Arrangement, as at 30 June 2009," TAD/PG(2009)17/Final, Paris.

Petersen, M.A. and R.G. Rajan, 1997, "Trade Credit: Theories and Evidence," The Review of Financial Studies 10, pp.661-91.

Thomas, Alun, 2009, "Financial Crisis and Emerging Market Trade," Staff Position Note 09/04 (Washington: International Monetary Fund).

U.S. Department of Commerce, 2008, Trade Finance Guide: A Quick Reference for U.S. Exporters, Washington.

Wang, J.-Y., and H. Tadesse, 2005, "Overview," in J.-Y. Wang and M. Ronci, eds., Access to Trade Finance in Times of Crisis (Washington: International Monetary Fund), pp.115. 


\section{APPENDIX I. MARCH 2010 SURVEY RESULTS}

Table I.1. Changes in Value of Trade Finance Activities: By Types of Products (percent change)

\begin{tabular}{lcccccccc}
\hline & \multicolumn{1}{c}{ 2008Q4 vs. 2007Q4 } & \multicolumn{3}{c}{ 2009Q4 vs. 2008Q4 } \\
\cline { 2 - 10 } & All & Small & Medium & Large & All & Small & Medium & Large \\
banks & banks & banks & banks & Banks & banks & banks & banks \\
\cline { 2 - 11 } betters of Credit & 2 & 3 & 5 & -3 & -1 & -4 & -3 & 5 \\
Export Credit Insurance & 0 & -12 & 2 & 8 & 0 & 2 & -5 & 2 \\
ST and MT Trade Related Lending & -3 & -6 & 1 & -2 & 0 & 0 & -8 & 6 \\
\hline
\end{tabular}

Source: IMF/BAFT-IFSA Trade Finance Survey, March 2010.

Table I.2. Change in Value of Trade Finance by Region $2008 Q 4$ vs. $2007 Q 4$

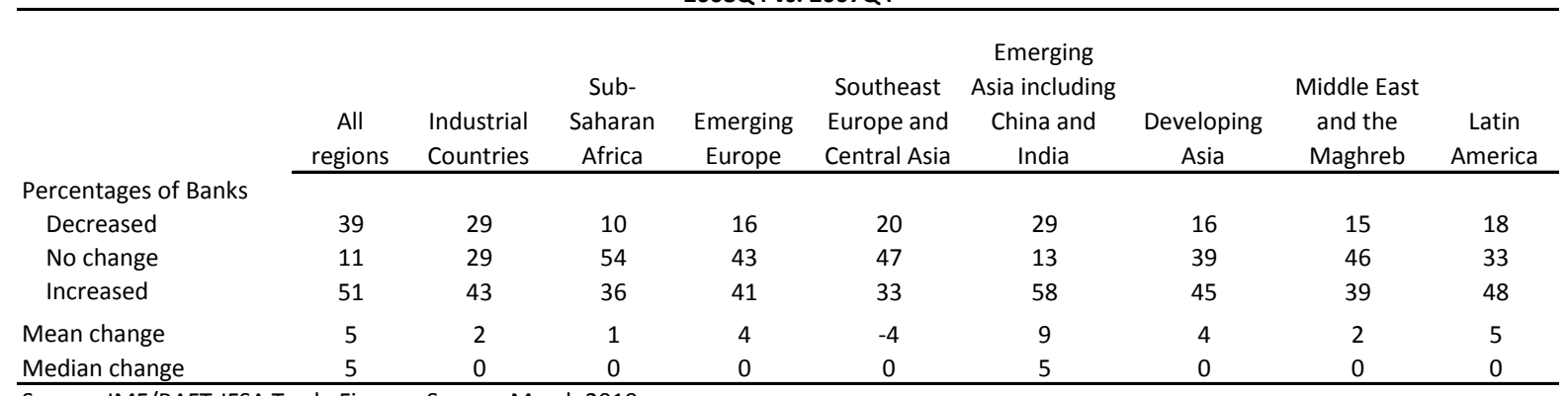

Source: IMF/BAFT-IFSA Trade Finance Survey, March 2010.

Table I.3. Change in Value of Trade Finance by Region $2009 Q 4$ vs. $2008 Q 4$

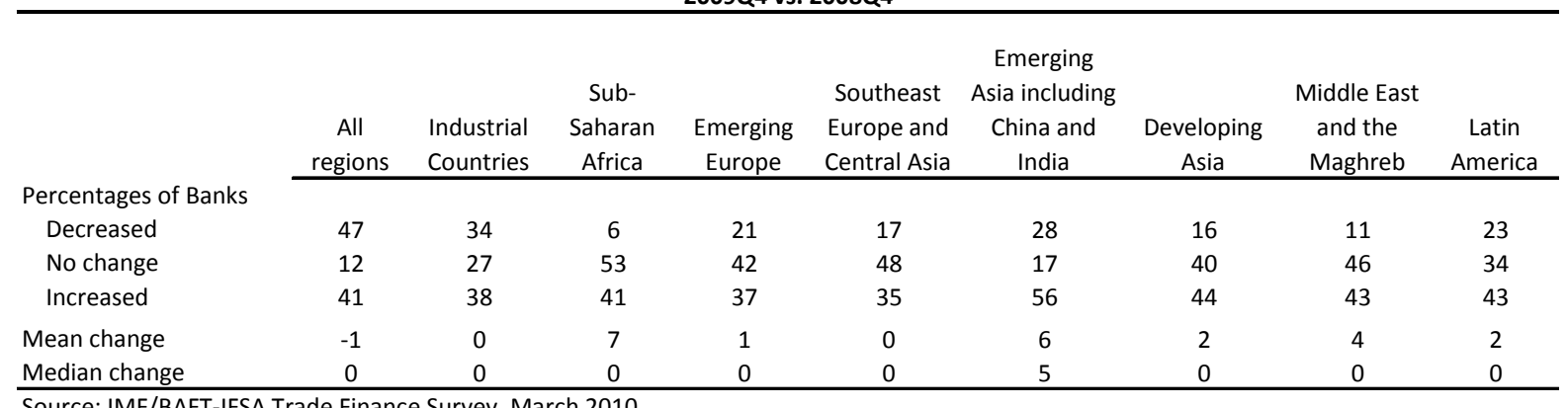

Source: IMF/BAFT-IFSA Trade Finance Survey, March 2010.

Table I.4. Change in Value of Trade Finance by Size of Bank $2008 Q 4$ vs. $2007 Q 4$

\begin{tabular}{lcccc}
\hline & \multicolumn{5}{c}{$\begin{array}{c}\text { Small } \\
\text { banks }\end{array}$} & $\begin{array}{c}\text { Medium } \\
\text { banks }\end{array}$ & Large banks \\
\cline { 2 - 5 } $\begin{array}{l}\text { Percentages of Banks } \\
\text { Decreased }\end{array}$ & 39 & 34 & 33 & 48 \\
No change & 11 & 3 & 18 & 10 \\
Increased & 51 & 62 & 48 & 42 \\
Mean change & 5 & 8 & 6 & 1 \\
Median change & 5 & 17 & 0 & 0 \\
\hline
\end{tabular}

Source: IMF/BAFT-IFSA Trade Finance Survey, March 2010. 
Table I.5. Change in Value of Trade Finance by Size of Bank $2009 Q 4$ vs. $2008 Q 4$

\begin{tabular}{lcccc}
\hline & All banks & $\begin{array}{c}\text { Small } \\
\text { banks }\end{array}$ & $\begin{array}{c}\text { Medium } \\
\text { banks }\end{array}$ & Large banks \\
\cline { 2 - 5 } Percentages of Banks & 47 & 52 & 55 & 35 \\
$\quad$ Decreased & 12 & 10 & 12 & 13 \\
No change & 41 & 38 & 33 & 52 \\
Increased & -1 & -9 & 0 & 6 \\
Mean change & 0 & -5 & -5 & 5 \\
Median change & & & & \\
\hline Source: IMF/BAFT-IFSA Trade Finance Survey &
\end{tabular}

Source: IMF/BAFT-IFSA Trade Finance Survey, March 2010.

Table I.6. Change in Value of Trade Finance by Location of Global Headquarters $2008 Q 4$ vs. $2007 Q 4$

\begin{tabular}{|c|c|c|c|c|c|c|c|c|c|}
\hline & $\begin{array}{c}\text { All } \\
\text { regions }\end{array}$ & $\begin{array}{l}\text { Industrial } \\
\text { Countries }\end{array}$ & $\begin{array}{c}\text { Sub- } \\
\text { Saharan } \\
\text { Africa 1/ }\end{array}$ & $\begin{array}{c}\text { Emerging } \\
\text { Europe }\end{array}$ & $\begin{array}{l}\text { Southeast } \\
\text { Europe and } \\
\text { Central Asia }\end{array}$ & $\begin{array}{c}\text { Emerging Asia } \\
\text { including } \\
\text { China and } \\
\text { India } \\
\end{array}$ & $\begin{array}{c}\text { Developing } \\
\text { Asia 2/ }\end{array}$ & $\begin{array}{l}\text { Middle East } \\
\text { and the } \\
\text { Maghreb 2/ }\end{array}$ & $\begin{array}{c}\text { Latin } \\
\text { America }\end{array}$ \\
\hline \multicolumn{10}{|c|}{ Percentages of Banks } \\
\hline Decreased & 39 & 52 & 100 & 17 & 38 & 20 & 75 & 0 & 22 \\
\hline No change & 11 & 12 & 0 & 0 & 0 & 20 & 0 & 25 & 13 \\
\hline Increased & 51 & 36 & 0 & 83 & 63 & 60 & 25 & 75 & 65 \\
\hline Mean change & 5 & -5 & -32 & 27 & 11 & 32 & -20 & 34 & 10 \\
\hline Median change & 5 & -5 & -32 & 25 & 25 & 17 & -32 & 25 & 17 \\
\hline
\end{tabular}

Source: IMF/BAFT-IFSA Trade Finance Survey, March 2010.

$1 /$ Only 1 bank is headquartered in Sub-Saharan Africa.

2/ Only 4 banks are headquartered in Developing Asia and the Middle East and the Maghreb each.

Table I.7. Change in Value of Trade Finance by Location of Global Headquarters $2009 Q 4$ vs. $2007 Q 4$

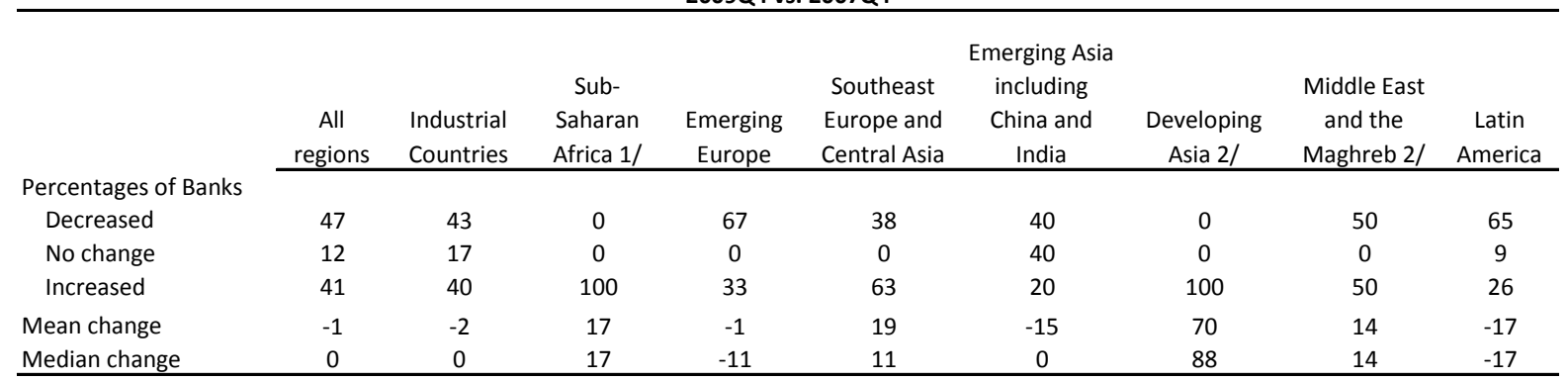

Source: IMF/BAFT-IFSA Trade Finance Survey, March 2010.

$1 /$ Only 1 bank is headquartered in Sub-Saharan Africa.

2/ Only 4 banks are headquartered in Developing Asia and the Middle East and the Maghreb each. 
Table I.8. Perceived Change in Use of Secondary Markets by Size of Bank

(percent of respondents)

\begin{tabular}{lcccc}
\hline & \multicolumn{5}{c}{$\begin{array}{c}\text { Small } \\
\text { banks }\end{array}$} & $\begin{array}{c}\text { Medium } \\
\text { banks }\end{array}$ & Large banks \\
\cline { 2 - 5 } $\begin{array}{l}\text { 201l banks } \\
\text { Increased vs. 2007Q4 }\end{array}$ & 25 & 17 & 23 & 32 \\
No change & 62 & 71 & 73 & 45 \\
Decreased & 13 & 13 & 3 & 23 \\
2009Q4 vs. 2008Q4 & & & & \\
Increased & 27 & 13 & 13 & 52 \\
No change & 60 & 88 & 70 & 29 \\
Decreased & 13 & 0 & 17 & 19 \\
\hline Source: IMF/BAFT-IFSA Trade Finance Survey, March 2010.
\end{tabular}

Table I.9. Experience with Probability of Default by Size of Bank (percent of respondents)

\begin{tabular}{lcccc}
\multicolumn{5}{c}{ (percent of respondents) } \\
\hline & $\begin{array}{c}\text { All } \\
\text { banks }\end{array}$ & $\begin{array}{c}\text { Small } \\
\text { banks }\end{array}$ & $\begin{array}{c}\text { Medium } \\
\text { banks }\end{array}$ & $\begin{array}{c}\text { Large } \\
\text { banks }\end{array}$ \\
\cline { 2 - 5 } $\begin{array}{l}\text { 2008Q4 vs. 2007Q4 } \\
\text { Increased }\end{array}$ & 32 & 28 & 16 & 53 \\
No change & 66 & 69 & 81 & 47 \\
Decreased & 2 & 3 & 3 & 0 \\
2009Q4 vs. 2008Q4 & & & & \\
Increased & 26 & 17 & 38 & 22 \\
No change & 61 & 69 & 56 & 59 \\
Decreased & 13 & 14 & 6 & 19 \\
\hline
\end{tabular}

Source: IMF/BAFT-IFSA Trade Finance Survey, March 2010. 


\section{APPENDiX II. July 2009 SURVEy Results}

\begin{tabular}{|c|c|c|c|c|c|c|c|c|}
\hline & & & & & & & Middle & \\
\hline & $\begin{array}{l}\text { Industrial } \\
\text { countries }\end{array}$ & $\begin{array}{c}\text { Sub- } \\
\text { Saharan } \\
\text { Africa } \\
\end{array}$ & $\begin{array}{l}\text { Emerging } \\
\text { Europe }\end{array}$ & $\begin{array}{l}\text { Southeast } \\
\text { Europe and } \\
\text { Central Asia }\end{array}$ & $\begin{array}{l}\text { Emerging Asia } \\
\text { incl. China and } \\
\text { India }\end{array}$ & $\begin{array}{c}\text { Developing } \\
\text { Asia }\end{array}$ & $\begin{array}{l}\text { East and } \\
\text { the } \\
\text { Maghreb }\end{array}$ & $\begin{array}{c}\text { Latin } \\
\text { America }\end{array}$ \\
\hline $\begin{array}{l}\text { Where are your trade finance } \\
\text { activities focused }\end{array}$ & 72 & 17 & 42 & 33 & 88 & 35 & 28 & 32 \\
\hline Where is your trade finance branch & 51 & 9 & 28 & 27 & 27 & 18 & 13 & 26 \\
\hline \multirow[t]{2}{*}{ Where is your global headquarters } & 49 & 1 & 13 & 9 & 1 & 8 & 2 & 17 \\
\hline & & & \multicolumn{2}{|c|}{ Small banks $(<\$ 5$ bn $)$} & \multicolumn{2}{|c|}{ Medium banks } & \multicolumn{2}{|c|}{ Large banks (> \$100 bn) } \\
\hline \multicolumn{3}{|c|}{ What were your bank's most recent total assets } & \multicolumn{2}{|r|}{40} & \multicolumn{2}{|l|}{32} & \multicolumn{2}{|c|}{28} \\
\hline
\end{tabular}

Table II.2. Changes in Value of Trade Finance Activities: By Types of Products (percent change)

\begin{tabular}{lcccccccc}
\hline & \multicolumn{3}{c}{ (percent change) } \\
\cline { 2 - 9 } & $\begin{array}{c}\text { All } \\
\text { Banks }\end{array}$ & $\begin{array}{c}\text { Small } \\
\text { banks }\end{array}$ & $\begin{array}{c}\text { Medium } \\
\text { banks }\end{array}$ & $\begin{array}{c}\text { Large } \\
\text { banks }\end{array}$ & $\begin{array}{c}\text { All } \\
\text { Banks }\end{array}$ & $\begin{array}{c}\text { Small } \\
\text { banks }\end{array}$ & $\begin{array}{c}\text { Medium } \\
\text { banks }\end{array}$ & $\begin{array}{c}\text { Large } \\
\text { banks }\end{array}$ \\
\cline { 2 - 10 } Letters of Credit & -2 & -1 & -9 & 3 & -8 & -5 & -12 & -7 \\
Export Credit Insurance & -5 & -7 & -10 & 5 & -12 & -17 & -5 & -15 \\
ST and MT Trade Related Lending & -2 & -5 & -6 & 5 & -11 & -9 & -17 & -7 \\
\hline
\end{tabular}

Source: IMF/BAFT-IFSA Trade Finance Survey, July 2009.

Table II.3. Changes in Merchandise Exports and Trade Finance: By Groups of Countries (percent growth)

\begin{tabular}{lcccc}
\hline & \multicolumn{2}{c}{$2008 \mathrm{c} 4$ vs. 2007Q4 } & \multicolumn{2}{c}{2009 Q2 vs. 2008Q4 } \\
\cline { 2 - 5 } Industrial Countries & Goods Exports & Trade Finance & Goods Exports & Trade Finance \\
\cline { 2 - 5 } Sub-Saharan Africa & -12.4 & -1.8 & -13.5 & -9.1 \\
Emerging Europe & -11.2 & -1.1 & -13.2 & -3.0 \\
Southeast Europe/Central Asia & -14.9 & -0.9 & -11.8 & -10.4 \\
Emerging Asia incl. China and India & -8.1 & -2.0 & -30.6 & -7.8 \\
Developing Asia & -0.4 & -1.0 & -18.0 & 0.0 \\
Middle East and the Maghreb & 0.4 & -5.5 & 0.8 & -3.8 \\
Latin America & 1.0 & 1.2 & 1.4 & -5.3 \\
Overall & -10.4 & -3.0 & -10.4 & -13.7 \\
\hline 1/WEightedave & -10.3 & $-1.91 /$ & -14.7 & $-7.51 /$ \\
\hline
\end{tabular}

$1 /$ Weighted average of regional changes by level of activity in respective region.

Source: IMF/BAFT-IFSA Tra de Finance Survey (July 2009), Haver Analytics, IFS, WTO. 
Table II.4. Reasons for the Decline in Value of Trade Finance 1/ (percent of respondents)

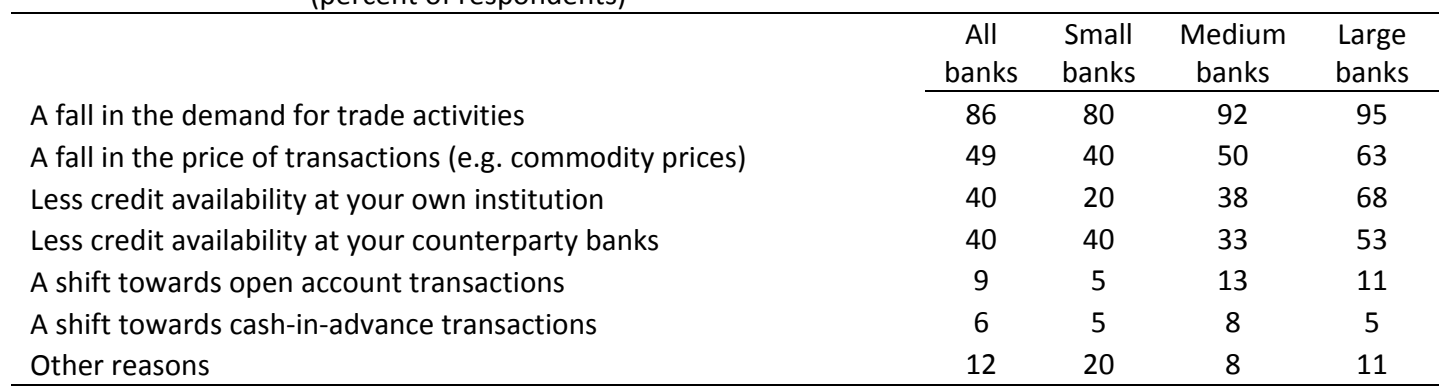

Source: IMF/BAFT-IFSA Trade Finance Survey, July 2009.

1 / This reflects only the views of the 65 respondents that reported a decline in value of trade finance in at least one geographic region presented and that subsequently marked at least one option for the current question.

Figure II.1. Has the pricing of the following trade instruments been affected by recent developments?

(percent of respondents)

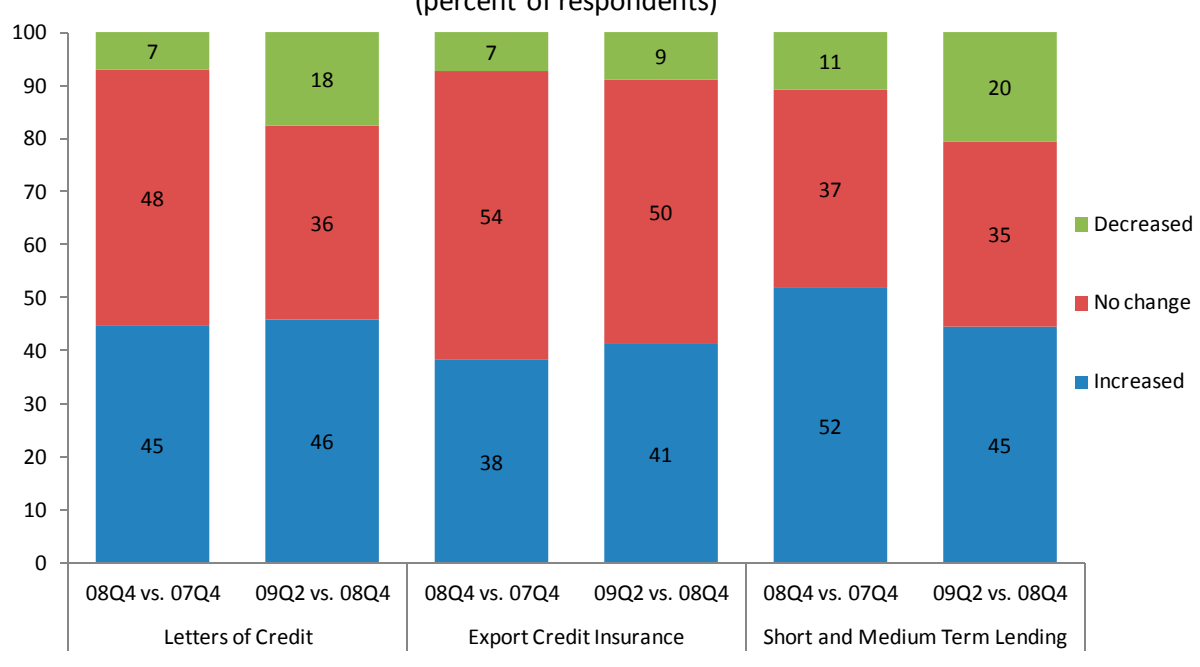

Source: IMF/BAFT-IFSA Trade Finance Survey, July 2009. 


\section{Figure II.2. Change in Pricing \\ (bps over cost of funds)}
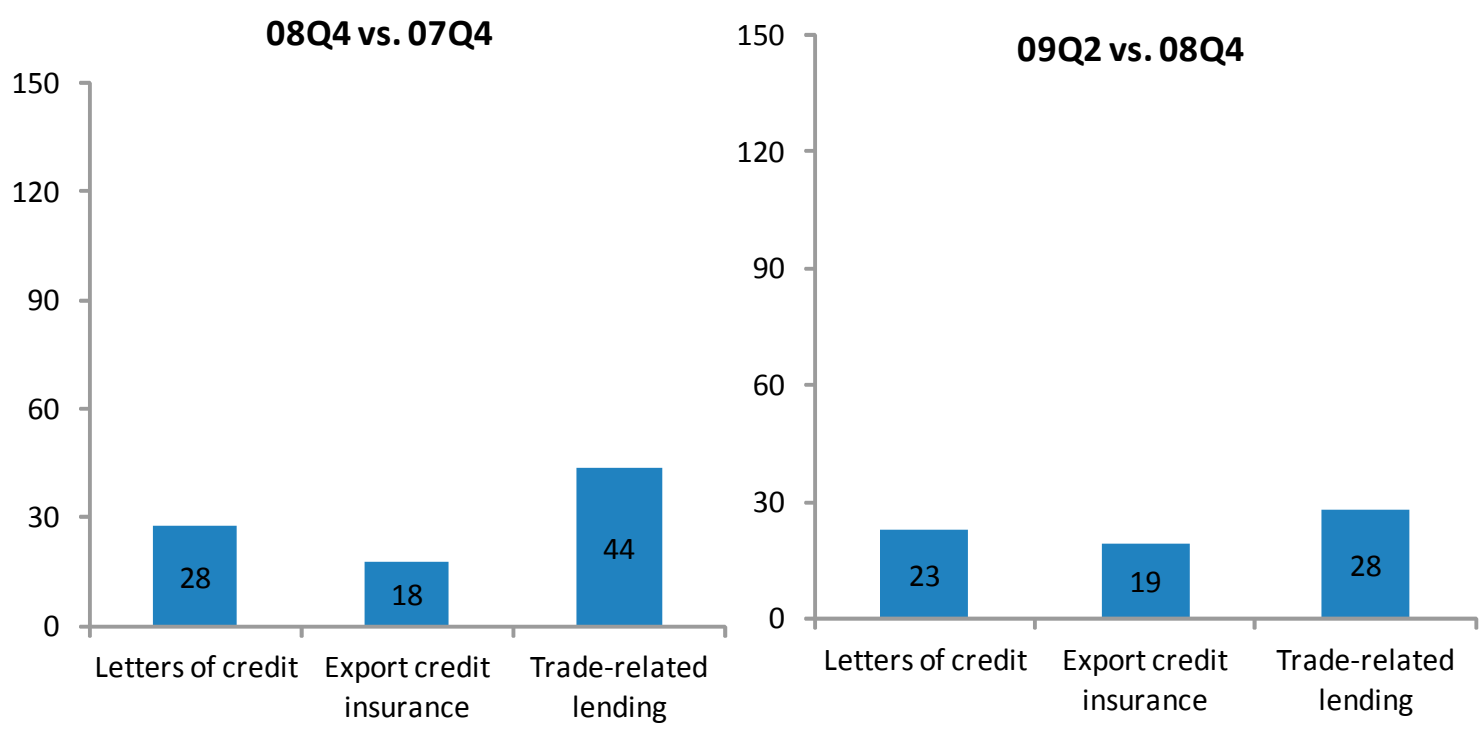

Source: IMF/BAFT-IFSA Trade Finance Survey, July 2009.

Table II.5. Reasons for the increase in prices $1 /$ (percent of respondents)

\begin{tabular}{|c|c|c|c|c|c|c|c|c|}
\hline & \multicolumn{4}{|c|}{$2008 Q 4$ vs. $2007 Q 4$} & \multicolumn{4}{|c|}{ 2009Q2 vs. $2008 Q 4$} \\
\hline & $\begin{array}{c}\text { All } \\
\text { banks }\end{array}$ & $\begin{array}{l}\text { Small } \\
\text { banks }\end{array}$ & $\begin{array}{l}\text { Medium } \\
\text { banks }\end{array}$ & $\begin{array}{l}\text { Large } \\
\text { banks }\end{array}$ & $\begin{array}{c}\text { All } \\
\text { banks }\end{array}$ & $\begin{array}{l}\text { Small } \\
\text { banks }\end{array}$ & $\begin{array}{l}\text { Medium } \\
\text { banks }\end{array}$ & $\begin{array}{l}\text { Large } \\
\text { banks }\end{array}$ \\
\hline $\begin{array}{l}\text { Own institution's increased cost of funds } \\
\text { Increased risk of trade finance products relative to }\end{array}$ & 66 & 65 & 63 & 70 & 52 & 55 & 50 & 50 \\
\hline $\begin{array}{l}\text { other working capital lending to the same non- } \\
\text { financial corporate borrowers }\end{array}$ & 47 & 50 & 58 & 35 & 47 & 50 & 55 & 35 \\
\hline Increased capital requirements & 29 & 15 & 26 & 45 & 37 & 30 & 45 & 35 \\
\hline Other & 24 & 15 & 16 & 40 & 28 & 25 & 15 & 45 \\
\hline
\end{tabular}

Source: IMF/BAFT-IFSA Tra de Finance Survey, July 2009.

$1 /$ This reflects only the views of respondents that reported an increase in pricing, and that subsequently answered this question.

Table II.6. Impact of Basel II on ability to provide trade finance 1/ (percent of respondents)

\begin{tabular}{|c|c|c|c|c|c|c|c|c|}
\hline & \multicolumn{4}{|c|}{$2008 Q 4$ vs.2007Q4 } & \multicolumn{4}{|c|}{ 2009Q2 vs. 2008 Q4 } \\
\hline & $\begin{array}{c}\text { All } \\
\text { banks }\end{array}$ & $\begin{array}{l}\text { Small } \\
\text { banks }\end{array}$ & $\begin{array}{l}\text { Medium } \\
\text { banks }\end{array}$ & $\begin{array}{l}\text { Large } \\
\text { banks }\end{array}$ & $\begin{array}{c}\text { All } \\
\text { banks }\end{array}$ & $\begin{array}{l}\text { Small } \\
\text { banks }\end{array}$ & $\begin{array}{l}\text { Medium } \\
\text { banks }\end{array}$ & $\begin{array}{l}\text { Large } \\
\text { banks }\end{array}$ \\
\hline $\begin{array}{l}\text { Not applicable (incl. Basel II has not been } \\
\text { implemented) }\end{array}$ & 19 & 50 & 20 & 11 & 9 & 17 & 11 & 0 \\
\hline No impact & 25 & 50 & 40 & 11 & 23 & 33 & 33 & 0 \\
\hline Positive impact & 0 & 0 & 0 & 0 & 5 & 17 & 0 & 0 \\
\hline Negative impact & 56 & 0 & 40 & 78 & 55 & 33 & 33 & 100 \\
\hline Other & 0 & 0 & 0 & 0 & 9 & 0 & 22 & 0 \\
\hline
\end{tabular}

Source: IMF/BAFT-IFSA Tra de Finance Survey, July 2009.

$1 /$ Includes only respondents reporting price increases due to increased capital requirements and that subsequently marked at least one option for the current question. 
Figure II.3. Have your trade-related lending guidelines changed since 2008Q4? (percent of respondents)

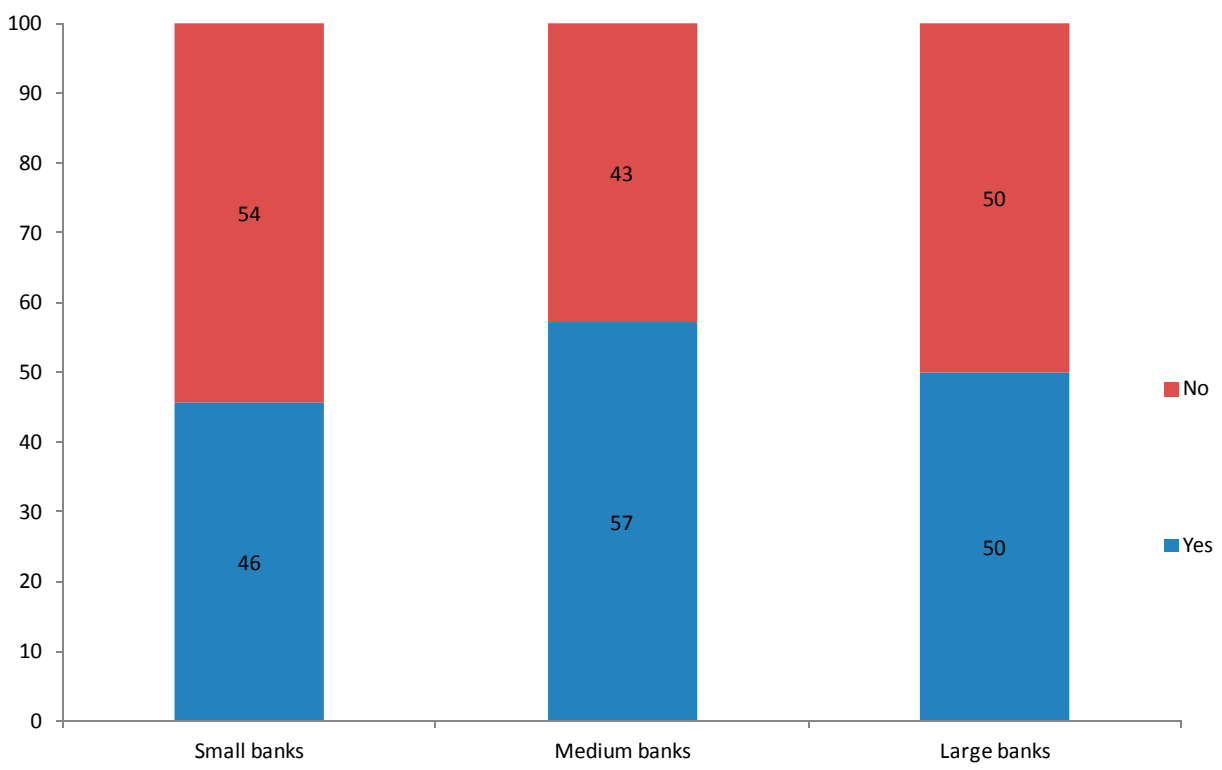

Source: IMF/BAFT-IFSA Trade Finance Survey, July 2009.

Table II.7. Change in Trade-Related Lending Guidelines 1/ (percent of respondents)

\begin{tabular}{lcccc}
\hline & $\begin{array}{c}\text { All } \\
\text { banks }\end{array}$ & $\begin{array}{c}\text { Small } \\
\text { banks }\end{array}$ & $\begin{array}{c}\text { Medium } \\
\text { banks }\end{array}$ & $\begin{array}{c}\text { Large } \\
\text { banks }\end{array}$ \\
\cline { 2 - 5 } $\begin{array}{l}\text { Become more cautious with certain sectors } \\
\text { Become more cautious with certain }\end{array}$ & 76 & 88 & 63 & 76 \\
$\begin{array}{l}\text { countries } \\
\text { Requested more collaterals (including equity }\end{array}$ & 78 & 50 & 81 & 100 \\
$\begin{array}{l}\text { contributions and cash deposits) } \\
\text { Requested shorter tenors }\end{array}$ & 65 & 81 & 44 & 71 \\
$\begin{array}{l}\text { Requested stronger covenants } \\
\text { Requested more DC or LC (including standby } \\
\text { and confirmed LC) }\end{array}$ & 53 & 69 & 50 & 41 \\
$\begin{array}{l}\text { Requested more Export Credit Insurance } \\
\text { Other }\end{array}$ & 41 & 44 & 38 & 41 \\
\hline
\end{tabular}

Source: IMF/BAFT-IFSA Trade Finance Survey, July 2009.

1 / This reflects only the views of the 49 respondents that reported a tightening in traderelated lending guidelines from 2008Q4 and that subsequently answered this question. 
Figure II.4. Change in the probability of default (percent of respondents)

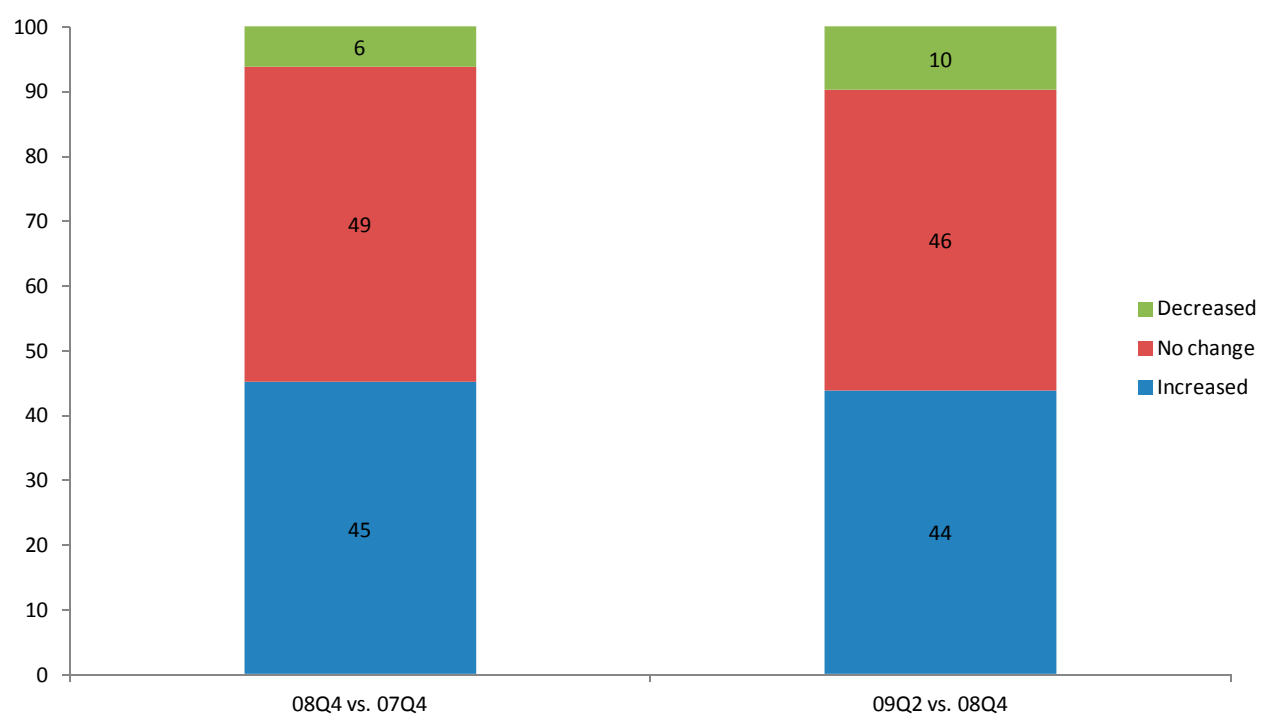

Source: IMF/BAFT-IFSA Trade Finance Survey, July 2009.

Figure II.5. Have you seen a change in the use of secondary markets? (percent of respondents)

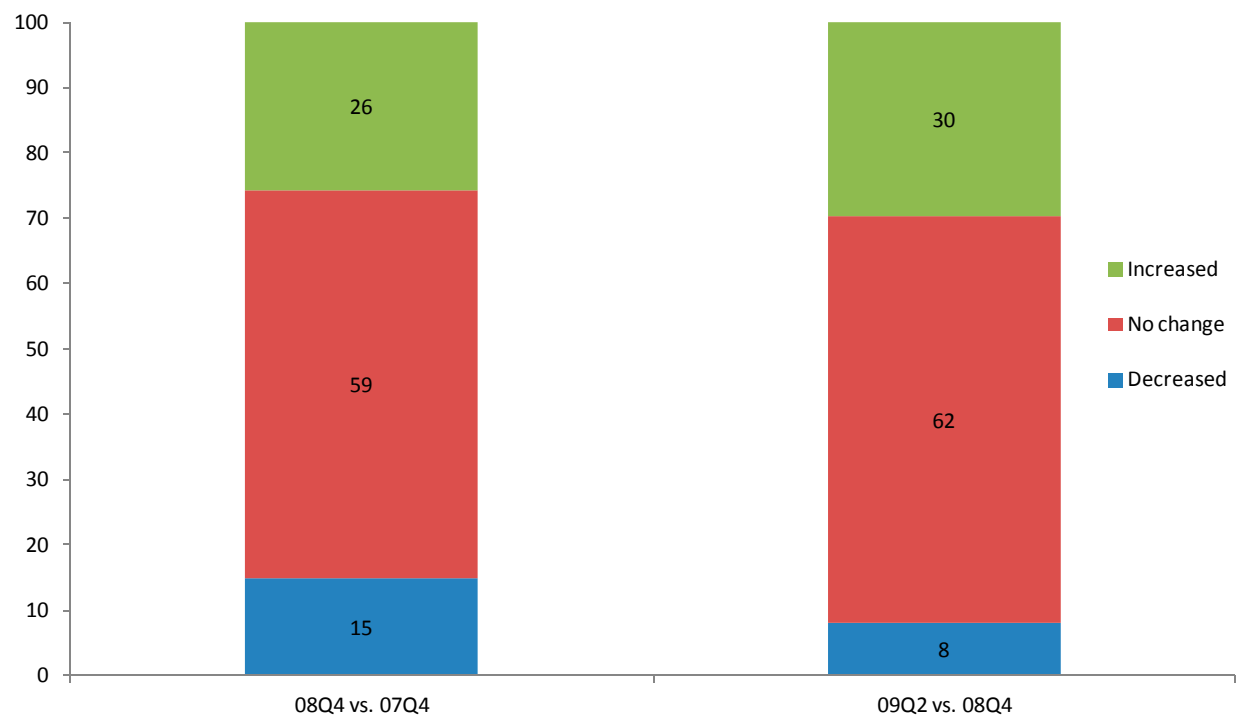

Source: IMF/BAFT-IFSA Trade Finance Survey, July 2009. 
Figure II.6. What is your "best" estimate for the composition of the Trade Finance industry as a whole?

(percent)

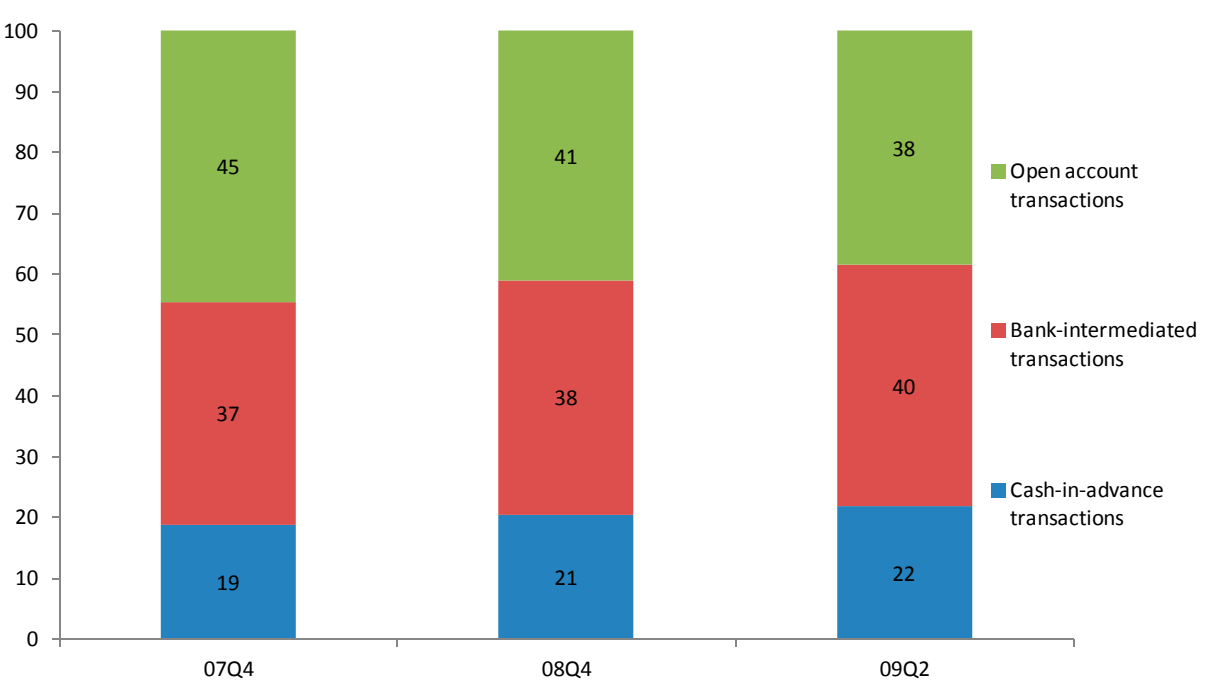

Source: IMF/BAFT-IFSA Trade Finance Survey, July 2009.

Figure II.7. Have you been able to satisfy all of your customer needs? (percent of respondents)

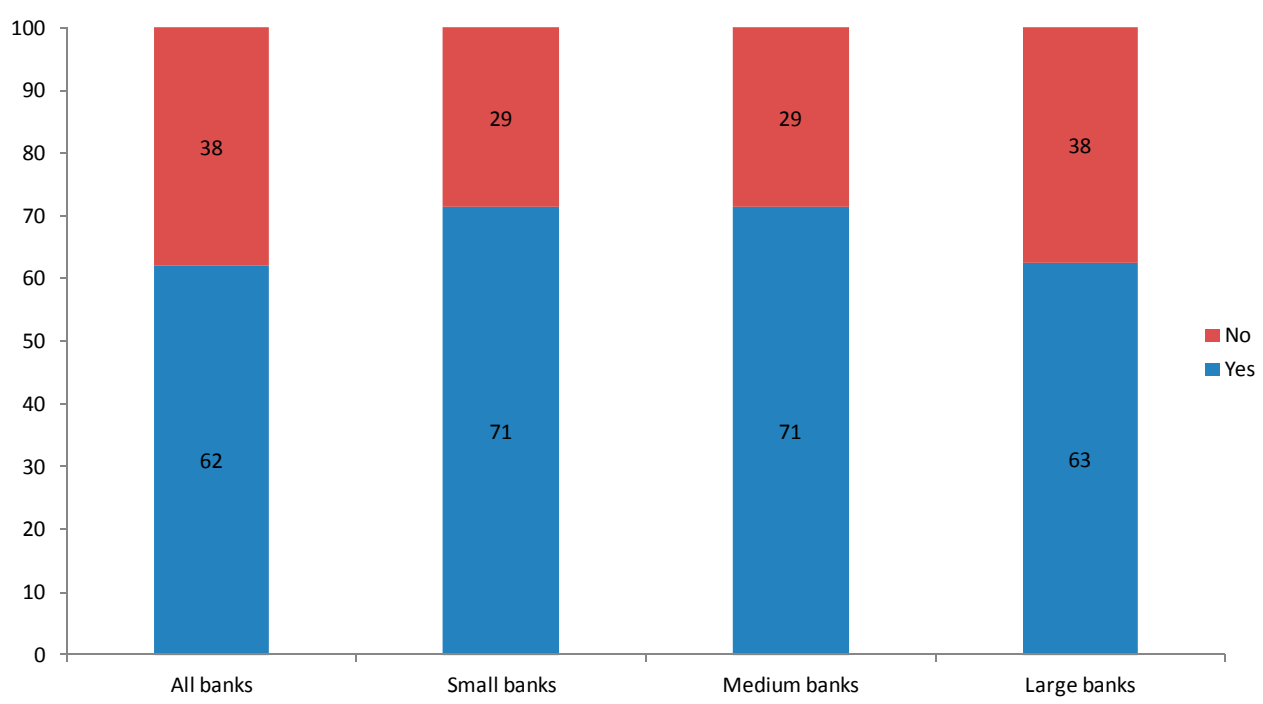

Source: IMF/BAFT-IFSA Trade Finance Survey, July 2009. 
Figure II.8. Are you confident that you can meet any increased demand for trade finance in the rest of 2009? 1/ (percent of respondents)

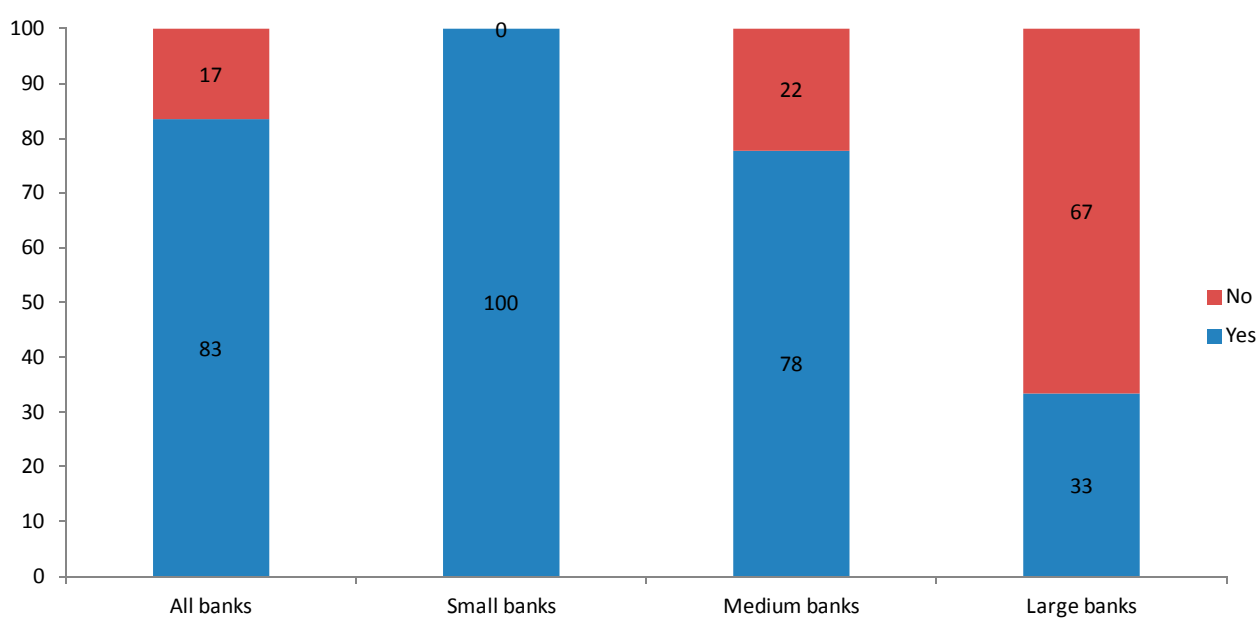

$1 /$ This reflects only the view of the 24 respondents that expect demand for trade finance to improve in the rest of 2009 and that subsequently answered this question. Source: IMF/BAFT-IFSA Trade Finance Survey, July 2009.

Table II.8. Outlook for Trade Finance Demand in 2009

(percent of respondents)

\begin{tabular}{lc}
\hline Further deterioration & 12 \\
Stabilization & 58 \\
Improvement & 28 \\
Other & 2 \\
\hline
\end{tabular}

Source: IMF/BAFT-IFSA Trade Finance Survey, July 2009.

Table II.9. Change in Value of Trade Finance by Region $2008 Q 4$ vs. $2007 Q 4$

\begin{tabular}{|c|c|c|c|c|c|c|c|c|c|}
\hline & \multirow[b]{3}{*}{$\begin{array}{c}\text { All } \\
\text { regions }\end{array}$} & \multirow[b]{3}{*}{$\begin{array}{l}\text { Industrial } \\
\text { Countries }\end{array}$} & \multicolumn{7}{|c|}{ Emerging } \\
\hline & & & & & Southeast & Asia & & Middle & \\
\hline & & & $\begin{array}{c}\text { Sub- } \\
\text { Saharan } \\
\text { Africa }\end{array}$ & $\begin{array}{c}\text { Emerging } \\
\text { Europe }\end{array}$ & $\begin{array}{c}\text { Europe and } \\
\text { Central } \\
\text { Asia }\end{array}$ & $\begin{array}{c}\text { including } \\
\text { China and } \\
\text { India }\end{array}$ & $\begin{array}{c}\text { Developing } \\
\text { Asia }\end{array}$ & $\begin{array}{l}\text { East and } \\
\text { the } \\
\text { Maghreb }\end{array}$ & $\begin{array}{c}\text { Latin } \\
\text { America }\end{array}$ \\
\hline \multicolumn{10}{|c|}{ Percentages of Banks } \\
\hline Decreased & 42 & 49 & 31 & 37 & 36 & 45 & 43 & 31 & 40 \\
\hline No change & 7 & 14 & 48 & 30 & 36 & 12 & 36 & 37 & 27 \\
\hline Increased & 51 & 37 & 21 & 33 & 28 & 43 & 21 & 31 & 33 \\
\hline Mean change & 4 & -2 & -1 & -1 & -2 & -1 & -6 & 1 & -3 \\
\hline Median change & 5 & 0 & 0 & 0 & 0 & 0 & 0 & 0 & 0 \\
\hline
\end{tabular}

Source: IMF/BAFT-IFSA Tra de Finance Survey, July 2009. 
Table II.10. Change in Value of Trade Finance by Region $2009 Q 2$ vs. $2008 Q 4$

\begin{tabular}{|c|c|c|c|c|c|c|c|c|c|}
\hline & \multirow{5}{*}{$\begin{array}{l}\text { All } \\
\text { regions } \\
\end{array}$} & \multirow{5}{*}{$\begin{array}{l}\text { Industrial } \\
\text { Countries }\end{array}$} & \multicolumn{7}{|c|}{ Emerging } \\
\hline & & & & & Southeast & Asia & & Middle & \\
\hline & & & Sub- & & Europe and & including & & East and & \\
\hline & & & Saharan & Emerging & Central & China and & Developing & the & Latin \\
\hline & & & Africa & Europe & Asia & India & Asia & Maghreb & America \\
\hline \multicolumn{10}{|c|}{ Percentages of Banks } \\
\hline Decreased & 61 & 62 & 33 & 46 & 39 & 47 & 39 & 39 & 54 \\
\hline No change & 11 & 12 & 52 & 36 & 34 & 11 & 34 & 36 & 32 \\
\hline Increased & 28 & 26 & 16 & 18 & 27 & 43 & 26 & 25 & 14 \\
\hline Mean change & -11 & -9 & -3 & -10 & -8 & 0 & -4 & -5 & -14 \\
\hline Median change & -5 & -5 & 0 & 0 & 0 & 0 & 0 & 0 & 0 \\
\hline
\end{tabular}

Source: IMF/BAFT-IFSA Tra de Finance Survey, July 2009.

Table II.11. Change in Value of Trade Finance by Size of Bank $2008 Q 4$ vs. $2007 Q 4$

\begin{tabular}{lcccc}
\hline & & & & \\
& All banks & Small banks & Medium banks & Large banks \\
\cline { 2 - 5 } Percentages of Banks & 42 & 34 & 57 & 36 \\
$\quad$ Decreased & 7 & 3 & 7 & 12 \\
No change & 51 & 63 & 36 & 52 \\
Increased & & & -3 & 4 \\
Mean change & 4 & 9 & -5 & 5 \\
\hline Median change & 5 & 11 &
\end{tabular}

Source: IMF/BAFT-IFSA Trade Finance Survey, July 2009.

Table II.12. Change in Value of Trade Finance by Size of Bank $2009 Q 2$ vs. $2008 Q 4$

\begin{tabular}{lcccc}
\hline & $\begin{array}{c}\text { All } \\
\text { banks }\end{array}$ & $\begin{array}{c}\text { Small } \\
\text { banks }\end{array}$ & $\begin{array}{c}\text { Medium } \\
\text { banks }\end{array}$ & Large banks \\
\cline { 2 - 5 } $\begin{array}{l}\text { Percentages of Banks } \\
\text { Decreased }\end{array}$ & 61 & 59 & 68 & 56 \\
$\quad$ No change & 11 & 9 & 4 & 20 \\
Increased & 28 & 31 & 29 & 24 \\
Mean change & -11 & -13 & -12 & -7 \\
Median change & -5 & -11 & -11 & -5 \\
\hline
\end{tabular}

Source: IMF/BAFT-IFSA Trade Finance Survey, July 2009.

Table II.13. Change in Value of Trade Finance by Location of Global Headquarters $2008 Q 4$ vs. $2007 Q 4$

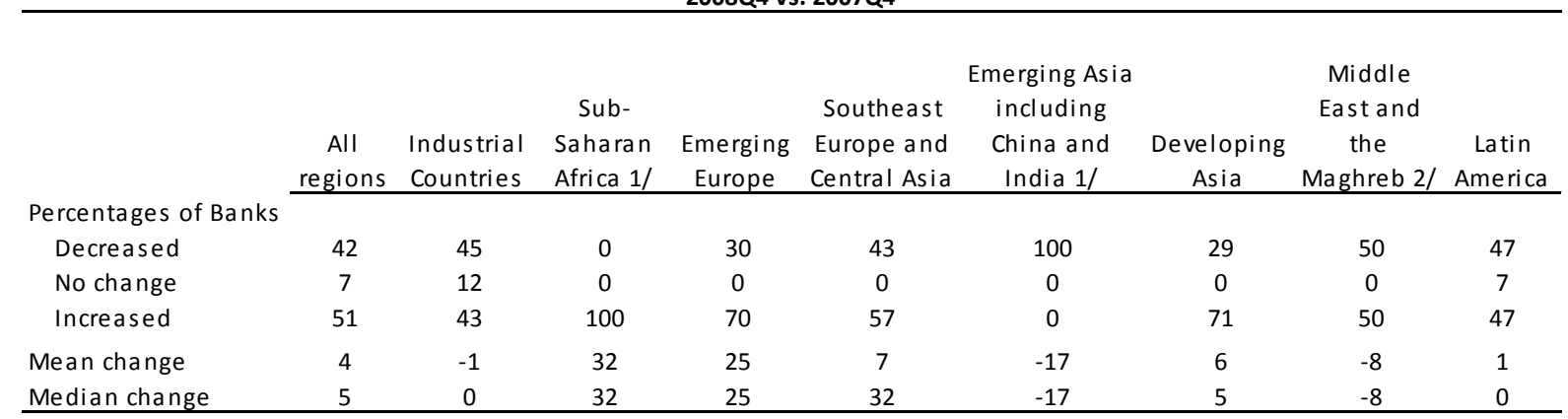

Source: IMF/BAFT-IFSA Trade Finance Survey, July 2009.

$1 /$ Only 1 bank is headquartered in Sub-Saharan Africa and Emerging Asia, respectively.

2/ Only 2 banks are headquartered in the Middle East and the Maghreb. 
Table II.14. Change in Value of Trade Finance by Location of Global Headquarters $2009 Q 2$ vs. $2007 Q 4$

\begin{tabular}{|c|c|c|c|c|c|c|c|c|c|}
\hline & $\begin{array}{c}\text { All } \\
\text { regions }\end{array}$ & $\begin{array}{l}\text { Industrial } \\
\text { Countries }\end{array}$ & $\begin{array}{c}\text { Sub- } \\
\text { Saharan } \\
\text { Africa 1/ }\end{array}$ & $\begin{array}{c}\text { Emerging } \\
\text { Europe }\end{array}$ & $\begin{array}{l}\text { Southeast } \\
\text { Europe and } \\
\text { Central Asia }\end{array}$ & $\begin{array}{c}\text { Emerging Asia } \\
\text { including } \\
\text { China and } \\
\text { India 1/ }\end{array}$ & $\begin{array}{c}\text { Developing } \\
\text { Asia }\end{array}$ & $\begin{array}{l}\text { Middle } \\
\text { East and } \\
\text { the } \\
\text { Maghreb 2/ }\end{array}$ & $\begin{array}{c}\text { Latin } \\
\text { America }\end{array}$ \\
\hline \multicolumn{10}{|c|}{ Percentages of Banks } \\
\hline Decreased & 61 & 55 & 100 & 90 & 57 & 100 & 57 & 50 & 60 \\
\hline No change & 11 & 19 & 0 & 0 & 0 & 0 & 14 & 0 & 0 \\
\hline Increased & 28 & 26 & 0 & 10 & 43 & 0 & 29 & 50 & 40 \\
\hline Mean change & -11 & -7 & -17 & -21 & -16 & -17 & -11 & -8 & -13 \\
\hline Median change & -5 & 5 & -17 & -32 & -17 & -17 & -5 & -8 & -32 \\
\hline
\end{tabular}

Source: IMF/BAFT-IFSA Tra de Finance Survey, July 2009.

$1 /$ Only 1 bank is headquartered in Sub-Saharan Africa and Emerging Asia, respectively.

2/ Only 2 banks are headquartered in the Middle East and the Maghreb. 
Table II.15. Pricing Changes by Size of Bank, $2008 Q 4$ vs. $2007 Q 4$ 1/ (percent of respondents)

\begin{tabular}{|c|c|c|c|c|}
\hline \multirow{3}{*}{ Letters of credit } & \\
\hline & $\begin{array}{c}\text { All } \\
\text { banks }\end{array}$ & $\begin{array}{l}\text { Small } \\
\text { banks }\end{array}$ & $\begin{array}{c}\text { Medium } \\
\text { banks }\end{array}$ & Large banks \\
\hline & & & & \\
\hline Increased & 45 & 26 & 44 & 71 \\
\hline No change & 48 & 68 & 48 & 21 \\
\hline Decreased & 7 & 6 & 7 & 8 \\
\hline Mean change & 28 & 27 & 27 & 31 \\
\hline Median change & 0 & 0 & 0 & 17 \\
\hline \multicolumn{5}{|c|}{ Export credit insurance } \\
\hline Increased & 38 & 20 & 43 & 55 \\
\hline No change & 54 & 68 & 52 & 40 \\
\hline Decreased & 7 & 12 & 4 & 5 \\
\hline Mean change & 18 & 10 & 22 & 23 \\
\hline Median change & 0 & 0 & 0 & 0 \\
\hline \multicolumn{5}{|c|}{ Trade-related lending } \\
\hline Increased & 52 & 36 & 52 & 74 \\
\hline No change & 37 & 45 & 41 & 22 \\
\hline Decreased & 11 & 18 & 7 & 4 \\
\hline Mean change & 44 & 36 & 50 & 48 \\
\hline Median change & 0 & 0 & 0 & 42 \\
\hline \multicolumn{5}{|c|}{ Average across products } \\
\hline Increased & 45 & 28 & 47 & 67 \\
\hline No change & 47 & 60 & 47 & 28 \\
\hline Decreased & 8 & 12 & 6 & 6 \\
\hline Mean change & 30 & 24 & 33 & 34 \\
\hline Median change & 0 & 0 & 0 & 20 \\
\hline
\end{tabular}

Source: IMF/BAFT-IFSA Trade Finance Survey, July 2009.

1 / Mean figures are percentage changes in the pricing margin above bank cost of funds. Mean and median figures do not include responses for which detailed pricing data were not provided. 
Table II.16. Perceived Change in Use of Secondary Markets

by Size of Bank

(percent of respondents)

\begin{tabular}{lcccc}
\hline \multicolumn{5}{c}{ (percent of respondents } \\
& All banks & $\begin{array}{c}\text { Small } \\
\text { banks }\end{array}$ & $\begin{array}{c}\text { Medium } \\
\text { banks }\end{array}$ & Large banks \\
\cline { 2 - 5 } 2008Q4 vs. 2007Q4 & & & & \\
Increased & 26 & 26 & 29 & 22 \\
No change & 59 & 70 & 54 & 52 \\
Decreased & 15 & 4 & 17 & 26 \\
& & & & \\
2009Q2 vs. 2008Q4 & 30 & 22 & 25 & 43 \\
Increased & 62 & 74 & 71 & 39 \\
No change & 8 & 4 & 4 & 17 \\
Decreased & &
\end{tabular}

Source: IMF/BAFT-IFSA Trade Finance Survey, July 2009.

Table II.17. Experience with Probability of Default by Size of Bank (percent of respondents)

\begin{tabular}{|c|c|c|c|c|}
\hline & All banks & $\begin{array}{l}\text { Small } \\
\text { banks }\end{array}$ & $\begin{array}{c}\text { Medium } \\
\text { banks }\end{array}$ & Large banks \\
\hline \multicolumn{5}{|c|}{$2008 Q 4$ vs. $2007 Q 4$} \\
\hline Increased & 45 & 33 & 60 & 46 \\
\hline No change & 49 & 61 & 32 & 50 \\
\hline Decreased & 6 & 6 & 8 & 4 \\
\hline \multicolumn{5}{|c|}{$2009 Q 2$ vs. $2008 Q 4$} \\
\hline Increased & 44 & 30 & 48 & 58 \\
\hline No change & 46 & 61 & 40 & 33 \\
\hline Decreased & 10 & 9 & 12 & 8 \\
\hline
\end{tabular}

Source: IMF/BAFT-IFSA Trade Finance Survey, July 2009. 


\section{APPENDIX III. Trade FinANCE SUPPly AND DEMAND FACTORS}

49. There several channels through which macroeconomic or broader financial market conditions and perceptions can feed through into trade finance.

50. Banks provide risk mitigation and liquidity for international trade based on their cost of funds and the amount of capital needed to back the risk associated with the individual transaction. Trade finance pricing is typically stated in terms of a margin above a bank's cost of funds and this margin is driven by the amount of the bank's capital that needs to be set aside against the risk of the financing. The factors affecting bank cost of funds are the same as those discussed for financial markets in general.

51. The amount of capital required to back a risk is a decision based on the bank's views of counterparty, country, and other risk factors, but also by supervisory regulations. Bank trade finance supply is constrained by the more stringent of the bank's own credit assessments of necessary capital to back a given risk and the regulatory minimum capital requirements. As bank risk perceptions rose and economic conditions deteriorated in the context of the crisis, banks required increasing amounts of capital to back all risk, including that associated with trade finance. Regulatory constraints have also been a public policy priority of both BAFT-IFSA and the ICC Banking Commission; they have argued in favor of modifications to Basel II and related national supervisory regulations to reduce the amount of capital needed to underpin trade finance.

52. The demand for bank-intermediated trade finance depends on the importers' and exporters' subjective assessments of risk and their risk aversion and the opportunity costs faced by both for working capital. Because banks may be better placed to assess and diversify counterparty risk, importers and exporters may find it in their interest to pay the banks to cover all or part of the payment/performance risks. In the context of the crisis, increased risk aversion on the part of importers and exporters increased their willingness to pay for bank trade finance in spite of increased pricing.

53. Demand for trade-related lending in the crisis depends very much upon the initial circumstances of importers and exporters and their change in access to trade-related and other forms of financing. "Blue chip" firms, particularly in advanced economies could often borrow for working capital or trade-related financing much more cheaply in the very low interest rate environment created when major central banks cut policy rates to historic lows. Cash-rich exporters may also have become more willing to tie up working capital in trade related receivables through open account terms as the near-zero interest rate environment reduced the opportunity cost of doing so. On the other hand, importers perceived as less creditworthy (e.g., small and medium-sized enterprises) or whose banks were reliant on wholesale funding from advanced economies (e.g., firms in some emerging markets) may have faced reduced availability and increased cost of unsecured working capital financing. These firms may have sought to increase trade-related borrowing to replace other forms of working capital financing. As a result, the impact of rising uncertainty on the demand for trade finance is ambiguous. 


\section{APPENDIX IV. INSTITUTIONS}

54. Trade finance takes many forms, from arrangements strictly between importers and exporters, to insurance services, to credit from banks. Each of these arrangements mitigates a different type and amount of risk.

55. The most common form of trade finance in normal circumstances is open account financing, in which the exporter extends credit to the importer directly, typically on some pre-specified terms (e.g., payment due 90 days from delivery), although there are many varieties of open account payments arrangements. The exporter bears both the credit risk (e.g., for non-payment) and the burden of providing liquidity in the transaction.

- $\quad$ Open account arrangements among unrelated parties rely on established relationships, trust, and reputation as an alternative to paying banks for risk mitigation.

- $\quad$ Some open account transactions are insured by ECAs. While these are not bank-intermediated trade finance, they are much more closely related to bank-provided export credit insurance than to other forms of open account financing.

- $\quad$ Much of international trade is intra-firm trade (e.g., trade between whollyowned subsidiaries of the same parent firm or other closely-related parties) and presumably has little if any need for bank or ECA trade finance.

56. Alternatively, exporters may require cash-in-advance or prepayment from importers (often involving a discount). This places the both the performance risk (e.g., for nondelivery) and the burden of providing liquidity for the transaction on the importer.

57. Bank-intermediated trade finance provides many intermediate approaches between open account and cash in advance that allow exporters and importers to use the banking system to: (i) verify delivery of goods; (ii) guarantee payment for goods upon delivery; and (iii) provide liquidity for the transaction before, during, and after shipment.

58. Good data on the prevalence of different forms of trade finance are not available. Fund staff estimates based on national data, academic studies, and our own surveys of banks suggest that the shares of global trade covered by different forms of trade finance are approximately as shown in Figure IV.1.

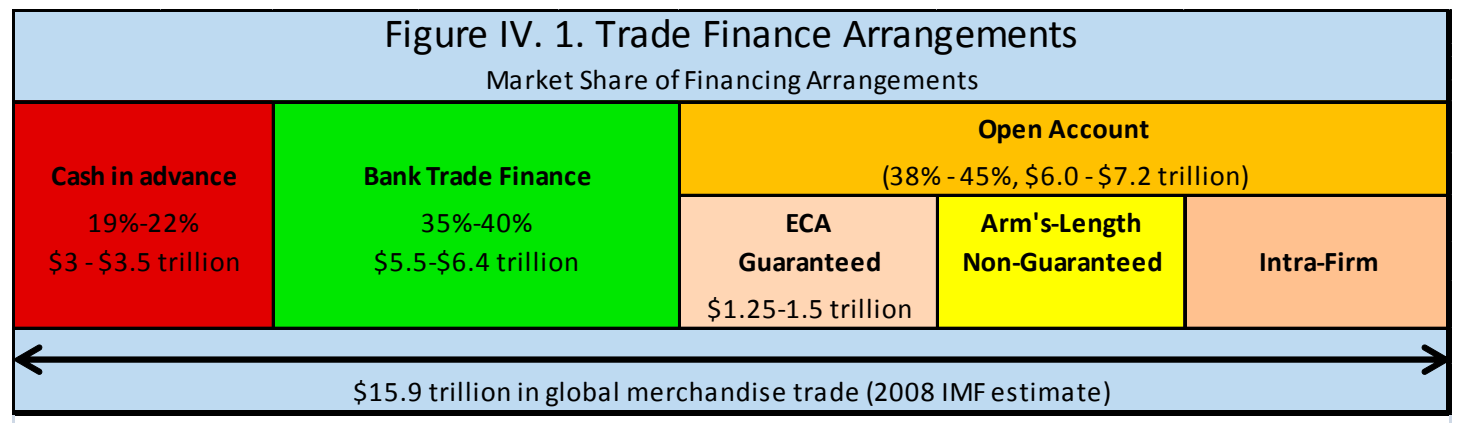

Source: IMF Staff estimates, IMF-BAFT Surveys of commercial banks, and Berne Union data. 
59. Bank-intermediated trade finance takes a variety of forms, the most familiar of which is the letter of credit. In their simplest forms, letters of credit (also known as documentary credits) use the banking system to guarantee payment for exports. A typical "unconfirmed" letter of credit is a guarantee by an issuing bank (typically the importer's bank) to the exporter that payment for the goods will be made upon presentation of documents confirming delivery (e.g., airbills or bills of lading). This arrangement would be most likely to be used in circumstances where the importer's creditworthiness may be lower or less known than that of the importer's bank. A letter of credit can also be "confirmed" by having a supplementary guarantee from another bank, typically the exporter's own bank. Confirmed letters of credit provide even greater protection to the exporter and would be particularly likely to be used where the exporter is concerned about the creditworthiness of the importer's bank or country risk associated with the importer's country.

Figure IV. 1. Letters of Credit

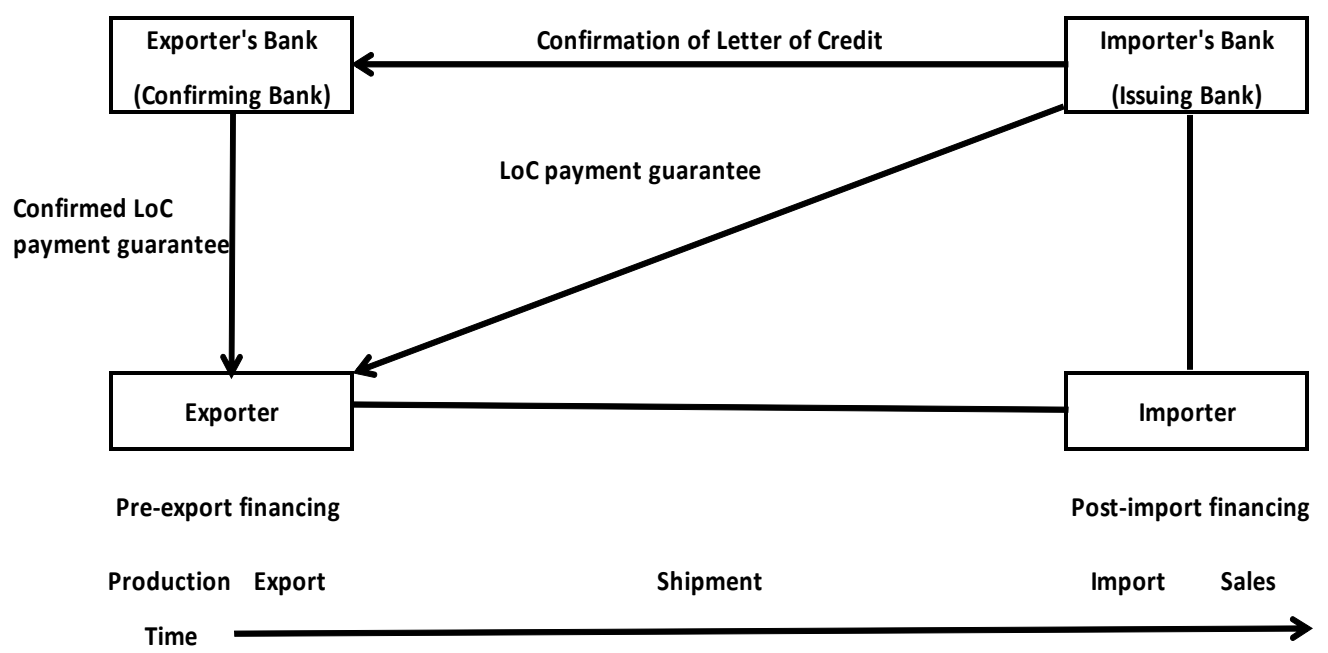

60. There are many other variations on bank-intermediated trade finance involving bank lending, risk mitigation, or other support for trade.

- $\quad$ Banks can provide liquidity in addition to guarantees to exporters in advance of shipment, either as export-related working capital or transaction-specific financing (e.g., financing to buy inputs and finance production for a specific capital goods export order).

- $\quad$ Financing can also be provided to the importers after the delivery of goods (e.g., to allow time to generate revenue by selling the imported goods).

- $\quad$ Banks can purchase trade receivables from the exporters at a discount in addition to guaranteeing payment, thus relieving the exporter of the need to provide liquidity for the transaction in addition to taking on the credit risk (forfaiting).

- $\quad$ Banks can provide more complex financing packages for exporters combining working capital credit, purchase of export accounts receivables, export credit insurance, and bookkeeping and documentary collection services. These are sometimes referred to export factoring or supply-chain financing. 
- $\quad$ Banks can facilitate trade without providing guarantees or liquidity by facilitating the delivery and processing of trade documentation as they would in a letter of credit transaction but without either bank assuming any risk for non-payment (documentary collections). ${ }^{13}$

61. Trade finance markets also have their own secondary markets in which the bank making the original trade finance contract can sell part or all of its exposure through syndicated loans, asset-backed securities, or bilateral transactions between banks. Banks use secondary markets to address risks from excessive concentrations of risk in individual importers, importing countries, or sectors. Although these do not directly affect the underlying individual exporter or importer, the benefits and risks to the efficient operations are analogous to those with asset-backed securities for other syndicated or securitized asset markets among financial institutions and the buyers of such collateralized securities.

\footnotetext{
${ }^{13}$ For more detail on the different forms of trade finance see U.S. Department of Commerce (2008).
} 
APPENDiX V. MEASURES BY NATIONAL GOVERnMENTS, ECAS, AND EXPORT-IMPORT BANKS

\begin{tabular}{|c|c|c|c|c|c|c|c|}
\hline \multirow[t]{2}{*}{ Country } & \multirow{2}{*}{$\begin{array}{l}\text { Introduced new } \\
\text { products }\end{array}$} & \multirow{2}{*}{$\begin{array}{c}\text { Increase in } \\
\text { capacity }\end{array}$} & \multicolumn{2}{|c|}{ Cover Policy/Guarantees $^{14}$} & \multicolumn{2}{|c|}{ Export credit } & \multirow[t]{2}{*}{ Other } \\
\hline & & & Introduced & Expanded & Introduced & Expanded & \\
\hline 1. Austria & & $\sqrt{ }$ & & $\sqrt{ }$ & & & \\
\hline 2. Australia & & $\sqrt{ }$ & & & & & \\
\hline 3. Belgium & & $\sqrt{ }$ & & $\sqrt{ }$ & & & \\
\hline 4. Canada & & $\sqrt{ }$ & & $\sqrt{ }$ & & & \\
\hline 5. China & & & & $\sqrt{ }$ & $\begin{array}{l}\sqrt{ }(\text { Jointly with } \\
\text { US Exim Bank } \\
\text { December 2008) }\end{array}$ & & $\begin{array}{l}\text { The People's Bank of China has } \\
\text { established a foreign currency credit line } \\
\text { from its reserves to facilitate access of } \\
\text { banks and exporters to trade financing. }\end{array}$ \\
\hline $\begin{array}{l}\text { 6. Czech } \\
\text { Republic }\end{array}$ & $\sqrt{ }$ & $\sqrt{ }$ & & $\sqrt{ }$ & & & $\begin{array}{l}\text { The government increased the capital of } \\
\text { the Czech Export Bank by about } € 40 \\
\text { million (April 2009). }\end{array}$ \\
\hline 7. Denmark & $\sqrt{ }$ & & & $\sqrt{ }$ & & & $\begin{array}{l}\text { Introduced and enhanced credit } \\
\text { assessment procedures. }\end{array}$ \\
\hline 8. Finland & $\sqrt{ }$ & & & $\sqrt{ }$ & & $\sqrt{ }$ & \\
\hline 9. France & & & & $\sqrt{ }$ & & & $\begin{array}{l}\text { The government created the Societe de } \\
\text { Financement de l'Economie Francaise } \\
\text { with the aim to enhance banks lending } \\
\text { capacity, including exporters. }\end{array}$ \\
\hline 10. Germany & & & & & & & $\begin{array}{l}\text { Introduced flexibility into interpretation } \\
\text { of commitment limit }{ }^{15} \text {. }\end{array}$ \\
\hline 11. Hungary & $\sqrt{ }$ & & & $\sqrt{ }$ & & & \\
\hline 12. Hong Kong & $\sqrt{ }$ & $\sqrt{ }$ & & $\sqrt{ }$ & & & $\begin{array}{l}\text { Free credit assessment and consulting } \\
\text { services, freeze on increase in premiums. }\end{array}$ \\
\hline 13. India & & $\sqrt{ }$ & & $\sqrt{ }$ & $\sqrt{ }$ & & \\
\hline
\end{tabular}

\footnotetext{
${ }^{14}$ The usage of terms of insurance cover and guarantees is interwoven/ combined in the discussions of many export credit agencies. While in both export credit and investment insurance the insurance is against specified risks or classes of risk (therefore conditional), individual policies may be referred to as guarantees. In addition, often, insurance policies are called guarantees. For instance, an insurance policy to an exporter in respect of short-term export credits might be called a short-term guarantee, etc.

${ }^{15}$ The use of term may vary among export credit agencies. In general, the commitment limit refers to total exposure of export credit agency to a country, includes all outstanding exposures on businesses already finalized and on offers made but not finalized, and all principal and outstanding contractual interest on loans extended by the agency (including undrawn or partially drawn facilities).
} 


\begin{tabular}{|c|c|c|c|c|c|c|c|}
\hline \multirow[t]{2}{*}{ Country } & \multirow{2}{*}{$\begin{array}{l}\text { Introduced new } \\
\text { products }\end{array}$} & \multirow{2}{*}{$\begin{array}{c}\text { Increase in } \\
\text { capacity }\end{array}$} & \multicolumn{2}{|c|}{ Cover Policy/Guarantees ${ }^{14}$} & \multicolumn{2}{|c|}{ Export credit } & \multirow[t]{2}{*}{ Other } \\
\hline & & & Introduced & Expanded & Introduced & Expanded & \\
\hline 14. Indonesia & & & $\begin{array}{l}\sqrt{ } \text { (pool fund } \\
\text { from support of } \\
\text { IFIs) }\end{array}$ & & & & \\
\hline 15. Italy & & & & $\begin{array}{l}\sqrt{ } \text { (working } \\
\text { capital) }\end{array}$ & & & \\
\hline \multicolumn{8}{|l|}{ 16. Japan } \\
\hline 17. Mauritius & & & & & & & $\begin{array}{l}\text { The central bank has established a } \\
\text { foreign currency credit line of US } \$ 125 \\
\text { million to enhance banks' access to forex } \\
\text { and their ability to provide trade } \\
\text { financing. }\end{array}$ \\
\hline 18. Korea & $\sqrt{ }$ & & & $\sqrt{ }$ & & & $\begin{array}{l}\text { The central bank has pledged } \$ 10 \text { billion } \\
\text { of its fx reserves to supply foreign } \\
\text { currency to local banks and importers for } \\
\text { trade finance purposes. }\end{array}$ \\
\hline $\begin{array}{l}\text { 19. The } \\
\text { Netherlands }\end{array}$ & $\sqrt{ }$ & & & $\sqrt{ }$ & & & \\
\hline 20. Norway & & $\sqrt{ }$ & & $\sqrt{ }$ & & $\sqrt{ }$ & \\
\hline $\begin{array}{l}\text { 21.New } \\
\text { Zealand }\end{array}$ & $\sqrt{ }$ & & $\sqrt{ }$ & & & & $\begin{array}{l}\text { The Government established a } \$ 480 \\
\text { million small business assistance } \\
\text { package aimed at simplification of tax } \\
\text { payment procedures. } \\
\text { Review of major regulatory legislation to } \\
\text { minimize red tape. }\end{array}$ \\
\hline 22. Poland & & & & $\sqrt{ }$ & & & \\
\hline 23. Singapore & $\sqrt{ }$ & & & & & & \\
\hline $\begin{array}{l}\text { 24. Slovak } \\
\text { Republic }\end{array}$ & & $\sqrt{ }$ & & $\sqrt{ }$ & & $\sqrt{ }$ & \\
\hline 25. Slovenia & & $\sqrt{ }$ & & & & & \\
\hline 26. Spain & $\sqrt{ }$ & $\sqrt{ }$ & & & & & $\begin{array}{l}\text { Administrative simplification of SME } \\
\text { coverage by CESCE }{ }^{16} \text {, and more advice. }\end{array}$ \\
\hline 27. Thailand & & $\sqrt{ }$ & & $\sqrt{ }$ & & & \\
\hline $\begin{array}{l}\text { 28. United } \\
\text { Kingdom }\end{array}$ & & & & $\sqrt{ }$ & & & \\
\hline
\end{tabular}

\footnotetext{
${ }^{16}$ Compañía Española de Seguros de Crédito a la Exportación, S.A (CESCE)
} 


\begin{tabular}{|c|c|c|c|c|c|c|c|}
\hline \multirow[t]{2}{*}{ Country } & \multirow{2}{*}{$\begin{array}{l}\text { Introduced new } \\
\text { products }\end{array}$} & \multirow{2}{*}{$\begin{array}{l}\text { Increase in } \\
\text { capacity }\end{array}$} & \multicolumn{2}{|c|}{ Cover Policy/Guarantees ${ }^{14}$} & \multicolumn{2}{|c|}{ Export credit } & \multirow[t]{2}{*}{ Other } \\
\hline & & & Introduced & Expanded & Introduced & Expanded & \\
\hline $\begin{array}{l}\text { 29. United } \\
\text { States }\end{array}$ & & & $\sqrt{ }$ & & & $\sqrt{ }$ & $\begin{array}{l}\text { Introduced the Fast Track System-an } \\
\text { expedited process for lenders to obtain } \\
\text { Ex-Im Bank approval for working capital } \\
\text { guarantees up to } \$ 25 \text { million per } \\
\text { transaction. }\end{array}$ \\
\hline
\end{tabular}


Appendix VI. Measures by Multilateral Development Banks

\begin{tabular}{|c|c|c|c|c|c|c|c|}
\hline \multirow{2}{*}{$\begin{array}{c}\text { Multilateral } \\
\text { Development } \\
\text { Bank (MDBs) }\end{array}$} & \multirow{2}{*}{$\begin{array}{l}\text { Name of the } \\
\text { product }\end{array}$} & \multirow{2}{*}{$\begin{array}{l}\text { Increase in } \\
\text { capital/ } \\
\text { funding }\end{array}$} & \multicolumn{2}{|c|}{ Guarantees } & \multicolumn{2}{|c|}{ Export credit } & \multirow[t]{2}{*}{ Additional information } \\
\hline & & & Introduced & Expanded & Introduced & Expanded & \\
\hline $\begin{array}{l}\text { International } \\
\text { Finance } \\
\text { Corporation } \\
\text { (IFC) }\end{array}$ & $\begin{array}{l}\text { Global Trade } \\
\text { Finance Program } \\
\text { (GTFP) } \\
\text { Global Trade } \\
\text { Liquidity Pool } \\
\text { (GTLP) }\end{array}$ & $\begin{array}{l}\sqrt{ } \text { (GTFP doubled } \\
\text { in early } 2009 \text { to } \\
\$ 3 \text { billion })\end{array}$ & $\sqrt{ }$ & $\sqrt{ }$ & $\sqrt{ }$ & & $\begin{array}{l}\text { The guarantees are available for all private } \\
\text { sector trade transactions that meet IFC's } \\
\text { eligibility criteria. } \\
\text { IFC together with a number of MDBs and } \\
\text { governments created and funded Global } \\
\text { Trade Liquidity Pool, which was approved } \\
\text { by the IFC Board in March } 2009 \text {. The GTLP } \\
\text { is funding trade transactions for up to } 270 \\
\text { days and will be self-liquidating once } \\
\text { conditions for trade finance improve. It } \\
\text { provides up to } \$ 50 \text { billion of trade liquidity } \\
\text { support over the } 2009-2011 \text {, with significant } \\
\text { co-financing from the private sector (as part } \\
\text { of the global effort to ensure the availability } \\
\text { of at least } \$ 250 \text { billion of trade finance over } \\
\text { the next two years). In order to reach this } \\
\text { objective, G- } 20 \text { agreed to provide } \$ 3-4 \\
\text { billion in voluntary bilateral contributions to } \\
\text { the IFC Pool. }\end{array}$ \\
\hline $\begin{array}{l}\text { Asian } \\
\text { Development } \\
\text { Bank (ADB) }\end{array}$ & $\begin{array}{l}\text { The Trade Finance } \\
\text { Facilitation Program } \\
(\text { TFFP) }(2005)\end{array}$ & $\sqrt{ }$ & & $\sqrt{ }$ & & $\sqrt{ }$ & $\begin{array}{l}\text { In } 2007 \text {, ADB introduced the Risk } \\
\text { Participation Agreement (RPA). Designed } \\
\text { with the aim to facilitate trade credit to ADB } \\
\text { members at the time of crisis, RPA provides } \\
\text { mitigation against commercial and political } \\
\text { risks associated with international trade. }\end{array}$ \\
\hline
\end{tabular}




\begin{tabular}{|c|c|c|c|c|c|c|c|}
\hline \multirow{2}{*}{$\begin{array}{c}\text { Multilateral } \\
\text { Development } \\
\text { Bank (MDBs) }\end{array}$} & \multirow{2}{*}{$\begin{array}{c}\text { Name of the } \\
\text { product }\end{array}$} & \multirow{2}{*}{$\begin{array}{c}\text { Increase in } \\
\text { capital/ } \\
\text { funding }\end{array}$} & \multicolumn{2}{|c|}{ Guarantees } & \multicolumn{2}{|c|}{ Export credit } & \multirow[t]{2}{*}{ Additional information } \\
\hline & & & Introduced & Expanded & Introduced & Expanded & \\
\hline $\begin{array}{l}\text { Inter American } \\
\text { Development } \\
\text { Bank (IADB) }\end{array}$ & $\begin{array}{l}\text { Direct Bank } \\
\text { Facilities (A/B } \\
\text { Loans) } \\
\\
\text { Guarantee facilities, } \\
\text { o/w Trade Finance } \\
\text { Facilitation Program } \\
\text { (TFFP) (2005) } \\
\text { Bond Issuance } \\
\text { Facility (capital } \\
\text { markets) (2005) }\end{array}$ & $\sqrt{ }$ & & $\sqrt{ }$ & & $\sqrt{ }$ & $\begin{array}{l}\text { The loans are intended to be used for } \\
\text { working capital needs associated with pre- } \\
\text { shipment imports of goods and services } \\
\text { required for future exports among others. In } \\
\text { countries where the banking system is not } \\
\text { experiencing a systemic crisis, the Bank may } \\
\text { offer A/B loans to qualified commercial } \\
\text { banks. } \\
\text { In the context of the response to global } \\
\text { crisis, the Program was enhanced from } \$ 400 \\
\text { million to } \$ 1 \text { billion. } \\
\text { IDB provides a partial credit guarantee. } \\
\text { These guaranteed bonds will be used by the } \\
\text { issuing entity to finance trade activities. }\end{array}$ \\
\hline $\begin{array}{l}\text { African } \\
\text { Development } \\
\text { Bank }\end{array}$ & $\begin{array}{l}\text { Trade Finance } \\
\text { Initiative (2009) }\end{array}$ & $\sqrt{ }$ & $\sqrt{ }$ & & $\sqrt{ }$ & & $\begin{array}{l}\text { In early 2009, Trade Finance Initiative of } \\
\text { US } \$ 1 \text { billion was established and a } \\
\text { framework for accelerated resource transfer } \\
\text { of African development Fund (ADF) was } \\
\text { introduced. The aim is to pool resources to } \\
\text { help member states during with the crisis. }\end{array}$ \\
\hline EBRD & $\begin{array}{l}\text { Trade Facilitation } \\
\text { Programme(1999) }\end{array}$ & $\begin{array}{l}\sqrt{ }(\text { In early } 2009, \\
\text { the program's } \\
\text { budget was } \\
\text { increased from } \\
€ 800 \text { million to } \\
€ 1.5 \text { billion })\end{array}$ & & $\sqrt{ }$ & & & \\
\hline
\end{tabular}




\section{APPENDiX VII. GROUPS OF COUNTRIES}

\begin{tabular}{|c|c|c|c|c|c|c|c|c|}
\hline Industrial Countries & Sub-Sahara A & rica & $\begin{array}{l}\text { Emerging } \\
\text { Europe }\end{array}$ & $\begin{array}{l}\text { Southeast } \\
\text { Europe and } \\
\text { Central Asia }\end{array}$ & $\begin{array}{l}\text { Emerging } \\
\text { Asia incl. } \\
\text { China } \\
\text { and India }\end{array}$ & Developing Asia & $\begin{array}{l}\text { Middle East and } \\
\text { Maghreb }\end{array}$ & Latin America \\
\hline $\begin{array}{l}\text { Australia * } \\
\text { Austria * } \\
\text { Belgium * } \\
\text { Canada * } \\
\text { Cyprus } \\
\text { Denmark * } \\
\text { Finland * } \\
\text { France * } \\
\text { Germany * } \\
\text { Greece * } \\
\text { Hong Kong SAR * } \\
\text { Iceland * } \\
\text { Ireland * } \\
\text { Israel * } \\
\text { Italy * } \\
\text { Japan * } \\
\text { Korea * } \\
\text { Luxembourg * } \\
\text { Malta } \\
\text { Netherlands * } \\
\text { New Zealand * } \\
\text { Norway * } \\
\text { Portugal * } \\
\text { Singapore * } \\
\text { Slovenia * } \\
\text { Spain * } \\
\text { Sweden * } \\
\text { Switzerland * } \\
\text { Taiwan Province of } \\
\text { China * } \\
\text { United Kingdom * } \\
\text { United States * }\end{array}$ & $\begin{array}{l}\text { Angola } \\
\text { Benin } \\
\text { Botswana } \\
\text { Burkina Faso } \\
\text { Burundi } \\
\text { Cameroon } \\
\text { Cape Verde } \\
\text { Central African } \\
\text { Republic } \\
\text { Chad } \\
\text { Comoros } \\
\text { Congo, Dem. } \\
\text { Rep. of } \\
\text { Congo, Rep. } \\
\text { of } \\
\text { Côte d'Ivoire } \\
\text { Djibouti } \\
\text { Equatorial } \\
\text { Guinea } \\
\text { Eritrea } \\
\text { Ethiopia } \\
\text { Gabon } \\
\text { Gambia, The } \\
\text { Ghana } \\
\text { Guinea } \\
\text { Guinea-Bissau } \\
\text { Kenya * } \\
\text { Lesotho } \\
\text { Liberia } \\
\text { Madagascar } \\
\text { Malawi } \\
\text { Mali } \\
\text { Mauritania } \\
\text { Mauritius }\end{array}$ & $\begin{array}{l}\text { Mozambique, } \\
\text { Rep. of } \\
\text { Namibia } \\
\text { Niger } \\
\text { Nigeria } \\
\text { Rwanda } \\
\text { São Tomé \& } \\
\text { Príncipe } \\
\text { Senegal } \\
\text { Seychelles } \\
\text { Sierra Leone } \\
\text { Somalia } \\
\text { South Africa * } \\
\text { Sudan } \\
\text { Swaziland } \\
\text { Tanzania } \\
\text { Togo } \\
\text { Uganda } \\
\text { Zambia } \\
\text { Zimbabwe }\end{array}$ & $\begin{array}{l}\text { Bulgaria * } \\
\text { Croatia * } \\
\text { Czech } \\
\text { Republic * } \\
\text { Estonia * } \\
\text { Hungary * } \\
\text { Latvia * } \\
\text { Lithuania * } \\
\text { Poland * } \\
\text { Romania * } \\
\text { Slovak } \\
\text { Republic * } \\
\text { Turkey * }\end{array}$ & $\begin{array}{l}\text { Albania * } \\
\text { Bosnia \& } \\
\text { Herzegovina * } \\
\text { Macedonia, } \\
\text { FYR } \\
\text { Montenegro } \\
\text { Serbia * } \\
\text { Armenia } \\
\text { Azerbaijan } \\
\text { Belarus * } \\
\text { Georgia } \\
\text { Kazakhstan * } \\
\text { Kyrgyz } \\
\text { Republic } \\
\text { Moldova } \\
\text { Mongolia } \\
\text { Russia * } \\
\text { Tajikistan } \\
\text { Turkmenistan } \\
\text { Ukraine * } \\
\text { Uzbekistan }\end{array}$ & $\begin{array}{l}\text { China * } \\
\text { India * } \\
\text { Indonesia } \\
* \\
\text { Malaysia * } \\
\text { Philippines } \\
\text { * } \\
\text { Thailand * } \\
\text { Vietnam * }\end{array}$ & $\begin{array}{l}\text { Afghanistan, I.S. of } \\
\text { Bangladesh } \\
\text { Bhutan } \\
\text { Brunei Darussalam } \\
\text { Cambodia } \\
\text { Fiji } \\
\text { Kiribati } \\
\text { Lao PDR } \\
\text { Maldives } \\
\text { Myanmar } \\
\text { Nepal } \\
\text { Pakistan * } \\
\text { Papua New } \\
\text { Guinea } \\
\text { Samoa } \\
\text { Solomon Islands } \\
\text { Sri Lanka } \\
\text { Timor-Leste, Dem. } \\
\text { Rep. of } \\
\text { Tonga } \\
\text { Vanuatu }\end{array}$ & $\begin{array}{l}\text { Bahrain } \\
\text { Egypt * } \\
\text { Iran, I.R. of } \\
\text { Iraq } \\
\text { Jordan * } \\
\text { Kuwait } \\
\text { Lebanon * } \\
\text { Libya } \\
\text { Oman } \\
\text { Qatar } \\
\text { Saudi Arabia } \\
\text { Syrian Arab Rep. } \\
\text { United Arab Emirates } \\
\text { Yemen, Rep. of } \\
\text { Algeria } \\
\text { Morocco * } \\
\text { Tunisia }\end{array}$ & $\begin{array}{l}\text { Antigua \& Barbuda } \\
\text { Argentina * } \\
\text { Bahamas, The } \\
\text { Barbados } \\
\text { Belize } \\
\text { Bolivia } \\
\text { Brazil * } \\
\text { Chile * } \\
\text { Colombia * } \\
\text { Costa Rica * } \\
\text { Dominica } \\
\text { Dominican Republic } \\
\text { Ecuador * } \\
\text { El Salvador } \\
\text { Grenada } \\
\text { Guatemala } \\
\text { Guyana } \\
\text { Haiti } \\
\text { Honduras } \\
\text { Jamaica } \\
\text { Mexico * } \\
\text { Nicaragua } \\
\text { Panama } \\
\text { Paraguay * } \\
\text { Peru * } \\
\text { St. Kitts and Nevis } \\
\text { St. Lucia } \\
\text { St. Vincent and the } \\
\text { Grenadines } \\
\text { Suriname } \\
\text { Trinidad and Tobago } \\
\text { Uruguay * } \\
\text { Venezuela * }\end{array}$ \\
\hline
\end{tabular}

Note: The classification used in the survey corresponds to the winter 2009 WEO classification. 


\section{APPENDIX VIII. GLOSSARY}

Advising bank: The advising bank is typically the exporter's regular bank in a letter of credit transaction. The advising bank acts as the agent for the exporter (also referred to as the beneficiary) in negotiating the letter of credit and facilitating communications with the importers bank (i.e., the issuing bank), but does not take on any payment risk. When the exporter's bank is providing a secondary guarantee in addition to that provided by the importer's bank, it is a confirming bank and the letter of credit becomes a confirmed letter of credit.

Bank-intermediated trade finance: This is a term specific to this paper to refer to those forms of trade finance in which commercial banks take on either credit risk or provide liquidity.

Basel II: The Basel II rules for trade finance established different and often higher capital requirements for trade finance assets than had existed under the Basel I rules. National implementation schedules differed for Basel II rules and some countries were not yet applying Basel II rules during the period of the surveys for this paper.

Basel II flexibility: Basel II prudential rules for banks entail setting capital requirements for trade finance (and certain other) assets with a maturity less than one year that are equivalent to those of assets with a maturity of exactly one year. However, it also provides national bank supervisors with the flexibility to exempt certain claims, including short-term trade finance assets, from this one year maturity floor if they choose to do so.

Berne Union. The Berne Union is the main association of export credit agencies and includes public, government-sponsored and private export credit insurers. Associated with the Berne Union is The Prague Club, an association for new export credit agencies. Notwithstanding the names, both are based in London.

Cash-in-advance: This implies pre-payment by the importer prior to the shipment of goods by the exporter. Cash-in-advance provides the greatest security to the exporter and the least security to the importer, and is typically used in small transactions or where importers are particularly concerned about the creditworthiness of the importer. Because cash-in-advance financing ties up the importers working capital and shifts all risk to the importer, it may be unacceptable to well-know, creditworthy, or established customers.

Confirming bank, Confirmed letter of credit: A confirmed letter of credit is one in which the exporter's bank (the confirming bank) provides a secondary guarantee to that provided by the importer's bank (i.e., the issuing bank). 
Cover: Insurance or risk mitigation for the exporter to cover risk of non-payment. This can take a variety of forms including letters of credit arranged by the importer or export credit insurance contracted by the exporter.

Documentary collection: Documentary collection refers to arrangements in which commercial banks play the same roles in document preparation, delivery, and verification as they do with letters of credit. However, neither the importer's nor the exporter's bank provide cover or liquidity in documentary collections. Instead, they are facilitating the processing of the transaction on a fee-for-service basis. For the purposes of this paper, documentary collections is not considered a part of bank-intermediated trade finance.

Documentary credits: A synonym for letters of credit that is used more often outside the U.S.

Export credit agency (ECAs): Export credit agencies are providers of insurance for international trade transactions. ECAs may be public, private, or government sponsored. Many currently private ECAs were previously in the public sector, and have subsequently been privatized. Some ECAs have hybrid arrangements with part of their business on purely private terms and part at the direction of the government, with the government bearing risk, providing liquidity or both. A typical ECA is chartered to provide export credit insurance to exporters of the country in which it is based, although some ECAs also provide direct lending and working capital financing in support of the country's exports. Most major ECAs are the members of the Berne Union.

Export credit insurance: Insurance sold to exporters against credit risk which would not necessarily involve a claim against the importer's bank. Export credit insurance generally covers less that the full value (e.g., 90 or 95 percent) of the exports. Export credit insurance can be provided by banks, other financial institutions and ECAs.

Factoring: Factoring refers to comprehensive trade-related financial services that combine export-related working capital, insurance, and other financial services for exporters. Factoring generally involves payments up front to the exporter by the bank or other financial institution and full absorption of payment risk by the financial institution (see also forfaiting).

Forfaiting: Forfaiting is the sale of trade finance receivables by an exporter to a financial institution at a discount to a bank or other financial institution. The buyer of the receivables generally absorbs all risk of non-payment. Forfaiting is generally only available for an ongoing stream of business rather than on a transaction-by-transaction basis.

Funded transaction: A trade finance transaction in which banks provide liquidity as well as risk mitigation. 
Letter of credit: A letter of credit is a payment guarantee on behalf of an importer by a bank (usually its regular bank) for which the exporter is the beneficiary. Payment is due upon presentation of specified documents such as commercial invoices, bills of lading, or other proof of purchase, shipment, or delivery and any other conditions such as the passage of a specified period of time. Notwithstanding its name, a letter of credit does not necessarily involve any lending by the banks. However, if may also involve bank lending if it allows the exporter to be paid by the issuing bank before the importer needs to pay the issuing bank.

Medium-term financing: Medium-term financing is defined differently in different trade finance contexts. In some contexts (e.g., Berne union data), it refers to financing with a maturity of more than one year, but in the context of the OECD arrangement, it refers to maturities of two to five years.

OECD arrangement: The Arrangement on Officially Supported Export Credits is an agreement among OECD member and certain other countries placing limitations on the terms and conditions for export credits (e.g., minimum interest rates) that are offered by government or government-affiliated ECAs with a maturity of two years or longer to ensure that ECAs operate in a manner that reflects market conditions. The OECD follows developments in shorter maturities, but the agreement does not apply to the short-term trade finance activities of ECAs.

Open account: Trade transactions in which the exporter receives payment from the importer after delivery of goods and without risk mitigation from the banking sector. This can include intra-firm or related-party trade, arm's-length trade between unrelated firms, and trade supported by ECAs. The last of these categories has much in common with bank-supported trade finance, but it is included in open account in this paper for measurement reasons.

Pre-export financing: Working capital lending to exporters to finance the production of goods for export.

Post-financing, post-import financing: Working capital lending to importers after goods are received (e.g., a line of credit to a wholesaler or retailer to financing the inventory of goods between the time of import and the time of sale to the final customer.

Secondary market: Transactions in which the bank making the initial trade finance transaction with a real-sector customer sells part or all of its claim to other institutions. This category ranges from bilateral transactions between two banks to limit exposure to a single counterparty or country to syndicated loans and asset-backed securities composed of tradefinance claims. 